UM Libraries Depository 


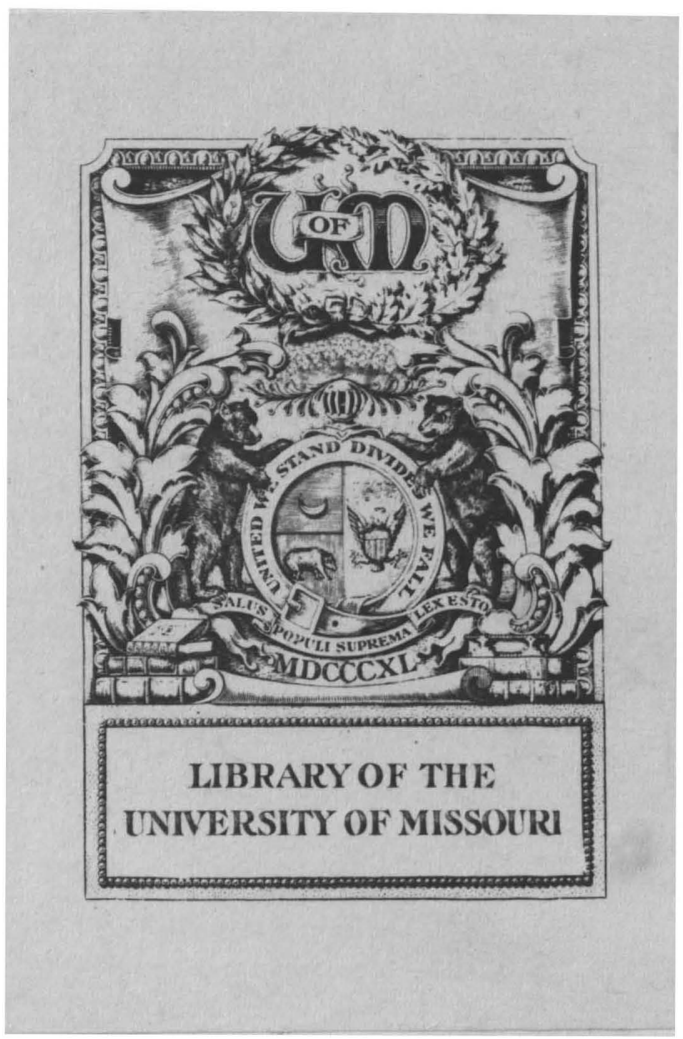

This Thesis Has Been

MICROFILMED

Negative No. T. 928

Form 26 






\section{OPPOSITION TO THE REEIECTION OF \\ THOMAS HART BENTON \\ IN 1844}

by

Clarence Henry McClure, B. S.

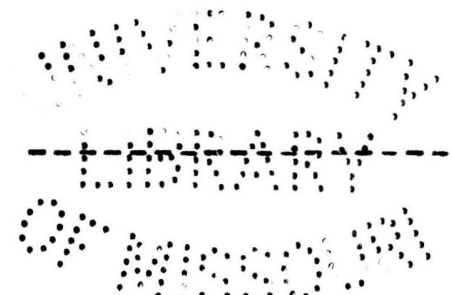

SUBMITIED IIN PARTIAI FUIFIIIMENT OF THE

REQU IREMEITS FOR THE DEGREE OF

MASTER OF ARTS

in the

GRADUATE SCHOOI

$$
\text { of the }
$$

UNIVERS ITY OF MISS OURI 

TABIE OF COITEITS.

pages .

IN IRODUCIIOIN

CHAPTER I. EARIY OPPOSITIOI TO BEITTOIN-BANKIIU

AIN CURREITCY • • • • • • • • • • • • 1

CHAPTER II. EARLY OPPOSITION TO BEITOIN - gONSTITUTIONAI QUESTIONS - • • • • . . . - . . 20

CHAPTER III. EARIY OPPOSIIION TO BEITON - ORGANIZAIION

OF FORCES • . . . . . . . . . 35

CHAPIER IV. COINEST FOR PARTY COITROI • • • • • • • • 64

CHAPTER V. CAIPAIGI AND EIECIION • • • • • • • • 99

BIBIIOGRAPHY . • • • . . • . • • . . . • 140

APPEITIX . . . . . . . . . . . . . . . . I4I 



\section{INTRODUC TION.}

In February, 1854, Thomas Hart Benton was defeated for reelection to the Senate of the United States. This defeat of Benton marked the culmination of one of the most exciting senatorial campaigns ever waged in the state. The Missouri legislature, March 7,1849, had passed some resolutions of instructions known, from C. F. Jackson who introduced them, as the Jackson resolutions, instructing the senators from Missouri to vote for the Calhoun resalutions on the slavery questions then pending in the United States Senate.

Benton refused to follow these instructions and appealed from the legislative instructions to the people of the state in a speech of great length delivered at Jefferson City,May 26, 1849, in which he denounced the Jackson resolutions as designed for electioneering and disunion purposes and as a mere copy of the Calhoun resolutions. This speech was followed by an exciting campaign which resulted in the election of a legislature composed of almost equal proportions of Whigs, Benton Democrats, and Anti-Benton Democrats. After a deadlock of several weeks the Anti-Benton Democrats went over to the Whig candidate Henry S. Geyer, of St.Iouis, and he was elected to succeed Benton.

The contest in which Benton lost his seat in the Senate has several characteristics which make it stand out prominently,

(1) Statesman, Jan. 31, 1851. 

not only in the life of Benton but also in the history of the state and even the nation. The passage of the Jackson resolutions marks a definite time at which the contest seemed to begin. Two questions which later became of great significance to the entire nation (the right of Congress to prohibit slavery in the territories and disunion) were the issues, and the fight was marked by one of the most spectacular and vindicitive speaking campaigns ever witnessed in our history. The apparent suddenness, the later significance of the issues involved, and the spectacular nature of the contest seems to have satisfied all investigatorg that the overthrow of Benton was to be attributed entirely to this contest and to the issues involved in it.

Meigs says, "So far as the records show, he (Benton) had little or no trouble to be reelected until his defeat in 185I, and he received on most occasions twice as many votes as his opponents or even more." (I) Iater Neigs makes the statement that in 1844, Benton received only 74 votes while his colleague Atchison received 101.(2) Rogers, after describing Benton's first election to the United States Senate, says, "This was Benton's only serious contest until 1850 wheh he lost his seat. For the next four terms Missouri reelected him without more than a formal vote." (3) Roosevelt says, "The large Whig minority had never been able to get control, but on the question of extension of slavery the dominant party itself began at this time (I) Meigs, Iife of Benton, p. 407.
(2) Ibid.,
(3) Rogers, Iife of Benton, p. 36. 

(1849) to break into factions. Hitherto Benton had been the undisputed leader of democracy, but now the pro-slavery and disunionist Democrats organized a very powerful opposition to him." (1)

In 1909, P.Orman Ray published a monograph on "The Repeal of the Missouri Compromise". In this work two chapters are devoted to Benton's contest for reelection in Missouri.(2) Ray places the beginnings of the contest in the summer of 1844; and makes the annexation of Texas, with special emphasis upon slavery and disunion, the issue which caused the beginning of the factional contest in Missouri. He says, "Despite the assault upon his position respecting Texas, Col.Benton was triumphantly reelected In January 1845, (3) and at the beginning of his fifth term was without question the most powerful man in Missouri politics" $(4)^{\prime \prime}$

The purpose of this study is to find the real beginnings of the opposition to Benton which culminated in his overthrow, and also to find the beginnings of the factions in the Democratic party in the state and the issues upon which the division was made. The Missouri sources show that Benton did have trouble to be reelected in 1844, that there was a serious contest to
(1) Roosevelt, Iife of Benton, p.35l.
(2) Ray's, Repeal of the Missouri Compromise,pp.27-71.
(3) Benton was reelected November 20,1844, See House Journal, $1844-45, \mathrm{p} .40$.
(4) Ray's, Repeal of the Missouri Compromise,p.33. 

overthrow him, that the dominant party began to break into factions long before 1849, or even 1844, that the break came upon the currency question, which was later allied to certain constitutional problems, and finally, that the Texas issue was seized upon by the already well organized opposition to Benton, and used effectively against him.

This study attempts to present these developments as they arose; first the split upon the currency issue, then the constitutional problems which were injected into the contest, the alignment of the factions in 1842 followed by the open assaut upon Benton, the contest for the control of party machinery and finally the campaign and election of Benton in 1844. 



\section{CHAPTER I.}

\section{GARIY OPPOSITIOIN TO BENTON- BAINKIIG AID CURREINCY.}

The purpose of this study is to describe the opposition to Thomas H. Benton which attempted and almost succeeded in effecting his overthrow in 1844 on the occasion of his fifth election to the United States Senate. Currency and Banking were the chlef issues in this fight against Benton. Therefore, Benton's policy upon these questions, the local Missouri problems connected with them and legislative and public opinion concerning them must be explained before a discussion of the actual fight is attempted. As the questions of banking and currency were national questions as well as state questions, and as Benton's chief work was in the United States Senate and his viewpoint was from the national side it is necessary to give some attention to the discussions and actions of Congress in order to get Benton's policy.

Among those opposed to the Second United States Bank probably Benton was the only leader who had a clear-cut, definite, constructive currency policy. At any rate he had such a policy. In his plan he had something to take the place of the banks, both the Bank of the United States and the state banks as well. Benton said that in the beginning

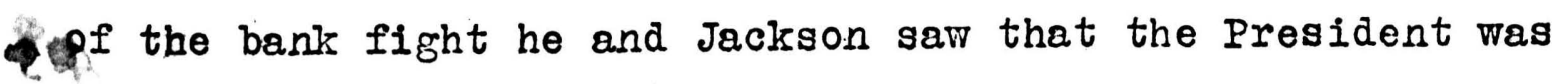
not strong enough to oppose both the United States Bank and 

the state banks at the same time. Therefore, it was necessary to use the state banks as a half way house. (1) Later in a speech Benton said, "I did not join in putting down the Bank of the United States to put up a wilderness of local banks. I did not join in putting down the paper currency of a National Bank to put up a national paper currency of a thousand local banks."(2)

Benton's plan based on an extensive study of the monetary systems of England, France and the Spanish Americas, was to divorce the government from all banks, to provide for the deposit of the government funds at the mints and in subtreasuries, and to encourage the use of hard money in every way possible. He would have had the government receive and pay out only hard money. (3) In order to further the use of specie in 1834 he secured a change of the ratio between silver and gold, from fifteen to one to sixteen to one. (4) This act was often referred to by Benton and his friends as

(1) Thirty Years' View, Vol. I.page 158.

(2) Meigs: Iife of Benton, p. 260.

(3) As evidence of proof of this statement see "Gales and Seaton's Register of Debates in Congress". Part I. Vol.10.183334. pages 1074-1107. This refers to a carefully prepared speech which Benton delivered in the senate upon the general subject of the currency during the consideration of the bill to recharter the second United States Bank, the chief object of which was to oppose the issue of paper currenoy, especially small notes, and to advocate the ratio of sixteen to one between silver and gold. He gave a detailed account of the ratios between silver and gold in England, France, Spain and the Spanish American countries, together with the subsidiary laws effecting the circulation of the two metals. This speech showed an extensive knowledge of European monetary conditions and might be considered a keynote speech to Benton's constructive currency policy although hể had been opposing the Bank of the United States for six years.

(4) Congressional Globe, Vol.X, Part I 1833-34, pp.1073-1107. 

the cause of the greater circulation of gold and its merit was acknowledged even by his enemies although they attempted to rob him of the credit for it. (I)

In 1836 when Congress had under consideration a bill creating some half dozen small banks for the District of Columbia, Benton opposed the bill and offered some amendments. These amendments and his speeches show his view. of what a bank should be, and what it should be allowed to do. One provision that he insisted on was that nothing but gold and silver should compose the capital of the bank. Bnother was that no notes of a lower denomination than twenty dollars should be issued. His reasons for the last named restriction were: first, that small notes banished silver and gold from circulation: second, that they were easily counterfeited and circulated among a class of people who were not skilled in detecting counterfeit money: and third, that small notes threw the burdens and losses of the paper system upon the laborers and small traders in the community, who have no share in the profits of banking and should not be made to bear its losses. Benton did not favor banks of issue at all, but he believed that banks should be restricted to receiving deposits and discounting notes. " If he must have banks of issue he clung tenaciously to the plan of

(1) Penn Letters, No.V. Missouri Register.Dec.12,1843. 

requiring a specie capital and prohibiting the issue of notes of small denomination. (I)

Benton's views, no doubt, had great weight in determining the course of banking and currency legislation in Missouri. The legislature was Democratic and its leading members were Benton's political friends and followed his lead upon all public questions. (2) While Benton was opposing and attempting to amend the Senate bill chartering the banks in the District of Columbia his political friends in the Missouri legislature were writine a part, at least, of his ideas of a bank into the charter of the Bank of Missouri. The most noticeable Bentonian feature of the charter was the clause prohibiting the issue of notes of a less denomination than ten dollars. (3) As shown in his speeches in the Senate Benton believed that if notes of small denomination were prohibited coin of small denomination would circulate among the people who handled only a small amount of money, and thus people who had only a little money would always have good money and could not suffer loss by the fluctuations of the currency.

(1) Thirty Years' Viev, Vol.I pp.639,660.

(2) For example John F. Darby who was a member of the Missouri legislature in the session of 1838-39 and introduced some hills for the construction of railroads attributec their defeat to Benton. He said that they were voted down by the Democratic majority of which Benton was the acknowledged head. Personal Recollections of John F. Darby, Page 181.

(3) Laws of Missouri 1836, p. 23. Bank Charter Sec.39. 

The hard money people were doomed to dissapointment so far as lifsouri was concerned. Their experiment did not receive a trial. Instead of coin of small denomination circulating as they had expected there was a great inflow of paper money of small denomination from other states, chicfly from Illinois. This influx was occasioned by the economic conditionsin st. Iouis. The situation in that city, its importance in the affairs of the state, its special vested interests, the connection of these interests with the currency and banking problems, and their opposition to Benton makes a consideration of conditions there necessary.

St. Iouis was the only city of any size in the state. It had a population of 16469 in 1840 which had increased to 63491 in 1845. (1) Its business and commercial interests were ke eping pace with the remarkable growth in population. In 1840 the imports were estimated at from ten to fifteen miliion dollars. In 1844 the annual trade was estimated at fifty million dollars. The registered average tonnage which was 14729 tons in 1842 had grown to 20420 in 1844, an increase of nearly forty per cent in two years. (2) It was the natural trade center, not only of Missouri, but also of Illinois, Iowa and Wisconsin. The banking business was naturally coming to be of great importance in such a commercial center,

(1) United States Census Report of 1850.Page 52. Table XXXIV. (2) Scharf: History of St. Iouis, page 1126. 

and there was an increasing demand for banking facilities and currency. However, the constitution of Missouri gave a monopoly, not only of the banking business of st.Louis but of the whole state as well, to one ingtitution. (I)

In 1837 the ninth session of the General Assembly made use of the power conferred by the constitution and created a banking institution to be called "The Bank of the state of Missouri". The capital stock was to be five million dollars and one half was to be reserved for the use of the state. The bank was to be managed by a president and twelve directors. The president and gix of the directors were to be elected by the General Assembly every two years. (2) The Bank was given power to issue bank notes, but prohibited from issuing any note of a lower denomination than ten dollars.(3) The public money of the state was to be deposited in the bank or its branches, and the bank was to act as the fiscal agent of the state, negotiate loans, and transfer money from one agency to another without charge to the state. (4) The charter provided that the bank should furnish the governor a statement (I) The clause on banks in the first constitution of Missouri is as follows: "The General Assembly may incorporate one banking company, and no more to be in operation at the same time. The bank to be incorporated may have any number of branches, not to exceed five, to be established by law; and not more than one branch shall be established at any one session of the General Assembly." First Constitution of Mis souri.Art.VIII. (2) Charter of the Bank,Session Acts of 1836-37.pages 12-28

(3) Charter of the Bank of Missouri,Sec.39.Session Acts of 1836-37.page 21 .

(4) Charter of the Bank, Session Acts of 1836-37 Sec.42. 

of all its affairs semi-annually; that the governor should, after the August election, appoint a committee of three newly elected members of the General Assembly, not stockholders in the bank, who should examine the bank and report its general condition to the legislature when it convened; and that either house of the General Assembly might appoint a committee to investigate the affairs of the bank. (I) The charter also contained the following clause: Whenever said bank shall stop specie payment, the charter shall cease and datermine; and it shall be placed in the hands of trustees appointed by the governor to settle the affairs of the bank". (2) From the above provisions of the charter of the bank two conclusions are evident; first, that the governor and General Assembly through the power to elect officers, require statements and appoint investigating committees could control the general policy of the bank; second, that the very existence of the bank required that it should not suspend specie payment.

On the 9th of 0ctober 1839 the banks of Philadelphia suspended specie payment. They were followed by all the banks of the South and West except the Bank of Missouri.(3) On Norember 12th the directors of the Bank of Missouri met

(I) Charter of the Bank.Session Acts of 1836-37

(2) Ibid.

(3) Scharf: History of St.Louis,page 1373. Sec.55. 

and passed a resolution "That the bank will in the future receive from and pay only to individuals her own notes and specie or the notes of specie paying banks." (I) There had been a general movement of specie to the East and the notes of the Bank of Missouri together with all the specie available was not sufficient to meet any considerable amount of the merchants' obligations daily falling due. (2) The notes of banks of other states formed the greater part of the local currency. By this act of the bank the notes of all suspended banks lost their character as money for the payment of debta. Great excitement was aroused among the merc-antile and industrial classes. The Missouri Republican of November 13th said, "The bank excitement continued very high during yesterday. In fact, it is the only subject matter of conversation or consideration. The merchants it might literally be said, have forsaken their counting rooms, and mechanics their shops. Wherever two or three met the action of the bank was the theme of conversation, and in every circle that we have fallen in with, whatever might be the politics of those composing it, the resolutions of the directors was condemned without measure or reserve. In truth, there never has been in this community so universal and unanimous a condemnation of any measure as this. Execrations loud and deep are freely uttered in every quarter, and by men of all parties."

(I) Scharf:His tory of St. Iouis, page 1373 .

(2) Edwards and HopeweIl: The Great West.page 368. 

The situation of the merchants was very serious. They could not get sufficient bankable money to meet their obligations. A meeting was called to consider the action of the bank, and it was reseolved "that, as the sense of this meeting, it will be no discredit to any individual having paper maturing this day at the Bank of Missouri to allow said paper to go to protest, if a tender is made at the bank or to the notary, of currency hitherto bankable and is refused". (I) The emergency was so great that several of the wealthier citizens offered to bind themselves legally to indemnify the bank for any loss it might sustain by depreciation of the notes heretofore received, if it would rescind its action. (2) The directors of the bank held a meeting but determined to adhere to their original action. When this became known an indignation meeting was called and the conduct of the bank severely condemned. Resolutions were adopted recommending that those doing business with the bank withdraw their deposits. As a result many of the heaviest depositors withdrew their funds and deposited them with some of the insurance companies or other corporations. (3)

(I) Scharf: History of St.Louis, page 1373.

(2) Edwards and Hopewell: Great West, p. 368.

(3) Ibid. 

On the opposite side of the Mississippi river and in territory commercially tributary to $\mathrm{St}$. Louis were numerous banks, practically without restriction and often disregarding those which were provided, issuing a great amount of paper currency of all denominations. (1) The inevitable result followed, Small foreign bank notes came in in large quantities. Clearly, the commercial needs of St.Louis together with the legal restrictions imposed upon and by the Bank of Missouri created most lucrative opportunities for 1llegal banking. These opportunities were made use of by the so-called insurance companies and other corporations of st. Louis.

Many of these corporations had been created by the legislature in 1836 and 1838. A law had also been passed in 1838 giving to County Courts the power to grant charters to industrial companies. This law was repealed in 1841, but many companies had been created in the meantime. (2) In 1840, the Jefferson Inquirer said that there were fifteen of these corporations in St. Louis, and that they had forced into circulation upwards of a million dollars of the depreciated

(1) Conant: History of Modern Banlss of Issue, pages 328,329 2337 . Knox:History of Banking.IIlinois Banks, page 720 . Ibid. Ibia. Indiana Banks, page 702 . Ibid. Wisconsin wildcat banks, page 747 . (2) Iaws of Missouri, $1838-39$, page 15.
Ibid. Ibia. 

currency of banks of other states and territories. (I) Their method of operation was described as follows: "St. Iouig owing to its situation is the center of capital for Illinois, Iowe and Wisconsin. The drpreciated paper from these sections naturally flows to St. Louls. The brokers, merchants and insurance companies are enabled to purchase large amounts of this depreciated currency at greatly reduced values. Then by agreement they proffer to sell eastern exchange for this paper. In this way the farmers and country merchants are induced to receive this currency for their produce. By this meang in the short space of from two to gix days they have raised this currency from 50\% to par value, and then dispose of the whole lot to speculators at a discount for the purpose of purchasing country produce. These operations are often repeated." (2) often companies were incorporated for a specific purpose, and instead of following that business did a banking business. An example of this was the St. Iouis Gas and Iighting Company, oreated for the purpose of lighting the city. It never engaged in the work of producing light, but immediately began a banking business, und in 1841 declared a dividend of 12\%. (3) These statements concerning the business methods of the insurance companies and other corporations were taken from the 

opposition press, but the fact that they were doing a banking business and speculating in depreciated currency is unquestioned. The legislature of 1840, following the recommendation of Governor Reynolds appointed a committee to investigate these companies. (I) The committee reported, "that the various companies have exercised banking privileges not granted by their charterg". (2) In a test case against one of the St. Iouis insurance companies Judge P. Hill Engle, of the Court of Common Pleas, decided that the company was engaged in an illegal banking business, and that its contracts were worthloss. (3)

In the early forties heavy issues of shinplaster were added to the depreciated bank notes of other states, thus further complicating the currency questions. Shinplasters were warrants issued by an incorporated political body, usually a city or a county. In 1841 the City of st. Iouis, and also St. Iouis County, issued large quantities of one, two and three dollar notes. (4) Boonville, Rocheport, Hannibal and Boone County all followed the example of St.Louis.(5) These warrants were issued in such immense quantities that redemption was impossible and rapid depreciation followed.

(1) Goverhor Reynolds: Inaugural Address, Senate Journal 1840. page 35.

(2) House Journal. Session 1840-41, pages 468-471.

(3) Jeffersonian Republican; July 24, 1841.

(4) Jefferson Inquirer "Dec. 30, 1841.

(5) Ibid. Feb.24, 1842. 

There were now so many kinds of paper money subject to continual fluctuations that elaborate quotations of notes were required, and brokers had a rich harvest in negotiating them. The business of these ingurance companies and brokers was very profitable, They became so strong that, it seems, they were enabled to largely control the poldtical leaders as. well as the press of both parties in the city. In these companies and their following is to be found the most determined and deepseated oppostion to the aggressive hard money legislative program, and especially to Benton who was recognized by all as the leader of the movement.

The exclusion from the state of this foreign paper currency became the chief object of Benton and his followers in Missouri politics. From 1838 to 1843 at each session of the legislature bills were introduced for this purpose. The penalties provided in the earlier bills were very severe, but this feature was mitigated gradually until the bill which finally became a law in 1843 was not especially marked by the severity of its penalties.

The importance of these bills in Benton's career makes it necessary to examine them in some detail. The first one was introduced by Redman of Hovlard County in the session of 1838-9. It provided that no person should pass or receive any bank notes or paper currency of a less denomination than twenty dollars (the notes of the Bank of Missouri excepted). It also provided that all money brokers or exchange dealers must take out a license for which they were 

required to pay one thousand dollars annually. 111 persons who violated this act by attempting to pass, by passing or by receiving paper currency were liable to the amount of the notes passed. Any agent, dealer or broker who violated the act was subject to a fine of ten thousand dollars. All persons convicted of violating the act were disqualified from holding any office in the state.(I)

This bill did not pass and in 1840 Governor Reynolds devoted a paragraph in his inaugural address to the currency question. He said, "The evils of an unsound and fluctuating ourrency are so apparent and universally felt, that it is needless to dwell upon their unhappy influence. This fluctuation is mainly the result of the operation of the suspended banks, and whether produced by design, to operate upon and control the elections of the country, or mismanagement the effect is equally disastrous and calls loudly for a corrective. The rightful authority of every state, to prescribe the kind of bank paper that should be permitted to circulate within it is denied by few. The policy that will increase the circulation of gold and silver, the standard of value, should be desired by all, and can only be attained to any considerable extent, while banks of issue exist, by the exclusion of small bank notes, which usurp the place of the precious metals. The people, by their representatives in 1836, decided, and that decision is jet unreversed, that the Bank of Missouri, the work

(I) Redman bill. Printed in the Miss ouri Register, Apr.9, 1844. 

of their own hands, and in which they are the largest stockholders, should issue no notes of a less denomination than ten dollars:and that policy would be suicidal which would extend to banks of other states privileges which we have denied our own. Concurring fully in the limitations imposed upon the Bank of Missouri, I should feel myself derelect in duty to our common constituents, if I omitted, on this occasion, to urge the propriety of prohibiting by law, under suitable sanctions, the circulation of all bank paper of a less denomination than ten dollars." (I)

Following this recommendation Redman introduced another currency bill similar to his former bill, but without such severe penalties. This bill simply provided that any person who passed paper currency of a less denomination than twenty dollars (the notes of the Bank of Missouri excepted) should be liable to the amount of the notes passed. Incorporated companies who violated the law were to forfeit their charters. (2) This bill passed the House but in the Senate it was postponed until the next session by a majority of one vote. It came up the last of the session and two democrats were absent. (3)

In 1842, Hugtoh, of Lincoln County, introduced two bills for the purpose of correcting the currency troubles. The first one provided that any corporation, corporate body or

(1) Governor's Inaugural Address: House Journal 1840,pages 28-33,

(2) Redman bills.Printed in Missouri Register,Apr.9, 1844.

(3) Hissouri Regis ter; Feb.25, 1841 . 

body politic, (except the Bank of Missouri) which issued currency, did a banking business of any kind, passed currency of any suspended bank, or any paper currency of a less denomincation than ten dollarg should forfeit its charter. The second provided that no paper currency of less denomination than ten dollars should be passed, and that currency of suspended banks should not be passed. All persons asking for license to follow any trade, profession, occupation, buginess or calling; or any one qualifying for a public office which paid fees were compelled to sign a written statement that they had not knowingly violated the provisions of this law. (I)

These bills were buried in committee and in their place two bills were reported back by C. F. Jackson. The Jackson bille passed and were approved by the governor, one February 17 th and the other February 23rd 1843. (2)

(I) These four bills, two by Redman and two by Huston, were called "bills of pains and penalties" by the Whigs and antiBenton Democrats. The clause of the Huston bill which required various classes of citizens to sign a statement declaring that they had not knowingly violated the provigi on of the act was referred to by the opposition press as a test oath. One of the campaign cries against Benton was "Bills of Pain and Penalties and Test Oaths".

(2) Mollagter, History of the United States Vol.VII, pages 10 and 11, tells a story of a riot in st. Louis which was directed against some of the currency brokers. He quotes a Philadelphia newspaper as his authority. Following the story of the riot and in the same paragraph, with the inference that the measures were the result of the riot, he says the legislature suppressed the script and forbad the oiroulation of bank notes under five dollars. He then gives references to the Jacks on acts of $\mathrm{Feb} .17$, and $\mathrm{Feb} .23,1843$. As can clearly be seen from the above discusgion these lawg firere the oulmination of the efforts of the Hard monely benish paper ourrency of gmall denomination from circulation. Thls purpose had been resolutely pursued for at least five 

These laws did not make the passing or receiving of paper money by a private citizen unlawful as the previous bills had sought to do. They provided that no corporation, corporate body or body politic lincluding the bank of M(ssourl and 1ts branches) nor any money lender or exchange broker should pass any bank note or paper currency of less denomination than ten dollars. Ior should they receive or pass ang suspended or non-specie paying bank notes or post notes issued as currency. These acts further provided that no corporation, corporate body or body politic (the Bank of Missouri and its branches excopted) should exercise any banking privilege either by 1ssuing notes, receiving deposits or discounting notes. The penglty for violation of the law was, In the case of corporations, corporate bodies or bodies politic, the forfelture of the charter of incorporation; in the case of money brokers or exchange dealers forfeiture of license and a fine of from $\$ 250$ to $\$ 1000$. (1) The essential difference between the Jackson bills which passed and all of the previons bills wes that these b1lls imposed no penalt1es upon the ordinary citizen and did not even make the passing or receiving of foreign bank notes unlawful.

These restriotive measures were important in the1r bearing upon the career of Benton and the rise of opposition to bim in two ways: first, the sererity of the pealties

Jears by Benton and his followers. Of four newspapers of the period,printed within the state,now accesible in the Missouri State Hiatorical Society I1brary at Columbla no one of them mentions the St/Louls riot in connection with the currency iegislation. Yet, all of them discuss the currenoy bills. (1) Jofferson Inquirer, Mar. 9,1843 . 

and their application to all citizens, it was alleged, indicated that the Hard money people were willing to sacrifice, or at least place in jeopardy, the well being and happiness of any citizen for the sake of a theory. This attitude was denounced as the worst of tyranny by the opposition. Second, the law which finally passed had the effect of driving out of a lucrative business a large and powerful clags of citizens of St. Iouis. Finally the authorship of and responsbility for these bills, which probably neither Benton nor of his.friends ever denied was brought home to him in the following manner. Edward Bates, of St.Iouis, in answer to an inquiry from the "Palmyra Whign, wrote that it was generally understood that Benton was the author of the Redman bill of 1838, but that he had no definite knowledge. However, he knew that Benton was the athor of the Huston bills. Huston had told him that Benton had written the bills and that afterwards he (Bates) had seen the original copies in Benton's own hand-writing in Huston's office in Troy,(1) After the appearance of Bates' letter, the Missourian, the Benton paper of st. Iouis, made the following comment: "It is perfectly well known that Col.Benton wrote letters and sent drafts of his bills to his friends at Jefferson City, to let them see precisely (1) Edward Bates was later a member of President Iincoln's Cabinet and servied as Attorney General from 1861 to 1863. The Statesman, a Whis paper of Columbia copied Bates' letter Irom the Palmyra Whig February 23,1844. 

what his ideas were. Those letters and bills were not secrets, but were frank and free communications, for the inspection of all who chose to see them. They were seen and read generally and (I) with more or less alteration were adopted and presented by members". These bills were designated as "Bills of Pains and Penalties" by the Whig and Anti-Benton, or Soft Democratic press, and became one of the chief campaign slogans of the opposition.

(1) Copied from the Missourian in the Statesman, Mar.15,1844, 

FARIY OPPOSITION TO BENTON - CONSTITUTIONAL QUESTIONS.

The question of the currency was the real, vital issue of politioal principle upon which the opposition to Benton arose in Missouri. Other questions were dragged in, but the real alignment came upon the currency question.l To Benton this was the all important question of state policy. His political friends in the atate government took up his side of the question and fought it to a successful issue, so far as law was concerned, and Benton, no doubt, considered himself under obligations to them for doing so. On other questions in which he was not personally interested Benton incurred bitter opposition for the sake of his political friends who had aided in securing his favorite currency laws. These questions were the reapportionment of representation in the lower house of the General Assembly, the limitation of judicial tenure of office, and the adoption of the district system in the election of congressmen. The first two questions caused a demand for a constitutional convention.

The life tenure of the judiciary was contrary to the 1deas of Jacksonian democracy which demanded that offices be passed around. The state constitution provided that each county should have one representative but that the total number of representatives should never exceed one hundred. As the frontier counties increased in number and st. Iouid 

and the older portions of the state increased in population representation became unequal and the value of a man's vote in state legislation was much greater in the thinly populated frontier counties than it was in st.Iouis. The solution of these problems could be effected either by amendments to the constitution, proposed and passed by the legislature, or by a constitutional convention. Both methods were proposed. In 1835 a proposal for a constitutional convention was submitted to the people and voted down, but the agitation became stronger and stronger until a convention was called in 1845. This agitation must be considered in connection with the rise of the opposition to Benton.

One clause of the constitution provided that one bank and no more might be ereated and that the bank might have five branches and no more. (I) Those who favored removing this restriction on banking naturally favored a constitutional convention. The Whigs as a political party, and also the citizenship in general in st.Louls without regard to party, desired the removal of the banking restriotions and were, therefore, general Iy in favor of a constitutional convention upon the issue of currency and banking as well as upon other 1ssues. On the other hand, the frontier counties, (2) (I) Constitution of 1820,Art.VIII.

(2) Probably the phenomenon of hard money frontiersmen needs some explanation. In Missouri the situation was a special one. The personal influence of Benton and the fact that he advocated hard money, no doubt, had much to do with public opinion. The experiences of Missouri in the money panic of 1819 attended by the failure of the territorial Bank of 

Benton and the Hard democrats were well satisfied with the banking restrictions and if there had been no other question involved would have voted againgt a constitutional convention. They were afraid that a constitutional convention would remove the restriotions againgt banking.

Misgouri and the Bank of St. Iouis with the depreciation of their paper currency and the consequent loss to the people probably had much to do with it. The people were told that the bankers and money changers were getting rich from their losses. They were made to belive that the banking aristocracy desired a fluctuating currency so that they might control its movements and spoculate on them. Thus sentiment was created against banking at just the right time to cause banking restrictions to be placed in the state constitution. Iater when the Bank of Missouri was chartered Benton's political friends succeeded in providing against the 1s sue of small notes. Then came the effort,to prevent the circulation of the small notes of the banks of other states, on the part of the Hard leaders. The lack of currenoy in St. Iouis really crippled business and when the Bank of Missouri refused to deal in the curreony of suspended banks in 1839 the insurance and other incorporated companies began a big business in this depreciatrd currency. The Hard money leaders then attacked the corporations and vested interests of St.Iouis and claimed that the losses of the people by depreciation of the various kinds of currenoy was not only due to the operation of these vested interests but that these logses of the people contributed directly to enrich the monopolies of st.Iouls. Thus a direct antagonism was created between st.Iouis and the frontier counties of the state. This antagonism was increased by differneces on other questions such as apportionment of representation, taxation, wolf-scalp laws, etc. The result was the phenomenon of a business community which might be expected to favor a sound currency favoring cheap money and striving to introduce the depreclated bank notes of the banks of other stater in order to supply the dire necessities of trade; while on the other hand the frontiersman because he thought he was being robbed by the vested interests of St.Iouis through the depreclated currency was strictiy in favor of hard money. 

A large and growing body of voterg were demanding a constitutional convention for the purpose of securing a readjustment of representation in the General Aesembly. The constitution of the state contained the following clause: "Each county shall have at least one representative but the whole number of representatives shall never exceed one hundred." (1) The result of this clause was a growing inequality in representation. The General Aseembly of 1836-37 made an apportionment of representatives for the ensuing four years as follows: St. Louls County seven, Boone County five, Howard County four, seven counties three each, eleven counties two each and the remaining thirty nine counties one oach. (2) The legislature of 1840-41 increased the number (of counties to seventy seven and the number of representatives to one hundred, the constitutional limit, and distributed them thus: St.Louis County seven, Boone and Howard counties three each, thirteen counties two each and the remaining sixty one counties one each. (3) The legislature of 1842-43 created nineteen new counties making a total of ninety six, and the legislature of 1844-45 in making the apportionment gave St. Louls County four representatives. Platte county two and the remaining ninety four counties one each. (4) The inequality of representation was now so great that Caldwell County with a total population of 1583 (5) had one representative while Boone County with a

(I) Constitution of 1820,Art.III.Sec.2.

(2) Laws of M1ssouri $1836-37$, page 5 .

(3) Ib1d 1840-41,page 8.

(4) Revised statutes of M1s souri 1845 page 113.'

(5) Census of 110 . 1844.House Journal 1844-45,Appendix, pege 158. 

total population of 14290 (I) had only one, and St.Louls County with a total population of 47668 (1) had only four, or approximately one representative for each 12000 inhabitants.

Th1s inequality tended to become greater as the population of St. Iouls increased much faster than that of the frontier counties. (2)

The older and more popupous counties were usually Whig. The new counties were Democratic. The Whigs of the older counties early saw what must happen to them as the number of counties was increased. Therefore, as early as 1832 the Whig members of the General Assembly began to fight the creation of new counties. (3) But the Democratic majority in the legislature together with the fact that the new counties vere sure to be Democratic made their fight a hopeless one from the beginning. Upon this question of reapportionment the interest of the older and more populous communties caused them to be very decidedly in favor of a constitutional convention. The frontier counties, however, were afraid a readjustment of representation might cause them to be grouped into legislative districts, and they did not care to loose their individual representatives.

(1) Cenaus of 1Ho.1844.House Journal 1844-45. Appendix,page 158 .

(2) The Census Report of 1850 gives the population of st.Iouis County 104978 and Caldwell County 2176. (page 655)

(3) Jefferson Inquirer, Oct. 26, 1843. 

Benton's political success was naturally favored by a large Democratic majority in the legislature, but there is no evidence that he objected to a constitutional convention on the question of reapportionment. While the interests of Benton and the Democratic party would cause them to oppose such a change the fundamental political principles which they professed, and which most of them really felt, demanded 1 t.

The third clause of the Constitution with which there was general dissatisfaction was the one providing for a judiclary.(1) This clause created a supreme court with three judges, and gave the General Assembly power to create circuit courts, as well as inferior courts. All the judges were appointed by the Governor and held office for life. The dissatidfaction was chlefly with the life tenure provision. The democracy thought these offices should be passed arouna. The very thought of an officer holding his position for life met with a negative response in the hearts of all good Missouri Demoorats, unless perchance it were the judges themselves. As the judges were all Democrats the Whigs were naturally willing to see the life tenure abolished. This argument for a constitutional convention appealed to more people and with stronger force than any other.

The Democrats tried, too late, to amend the old constitution and thus remove the judicial question as a cause for calling a congtitutional convention. In order to change the old constitu(1) Constitution of 1820, Art.V.Sec.13.V 

tion it was necessary that an amendment be passed by a two thirds vote by two consecutive legislatures. The legislature of 1842-43 which submitted the question of calling a constitutional convention to the people also passed an amendment limiting the judicial tenure of the supreme court judges to ten years and the circuit court judges to six years. The amendment also contained a clause which said, "that the offices of the several judges of the supreme court, and the several judges of the circuit courts of this state, shall be vacated on the first day of January 1845." (I) To make it a part of the constitution the amendment had to be passed again by the legislature of 1844-45. As its passage would have given the Governor the opportunity of immediately filling all the judicial offices of the state, and thus given him a chance to reward his political friends, the Hards, the Whigs voted solidly against the amendment when it came up for second passage, and it failed to receive the necessary two thirds vote.(2) The constitutional questions had been of sufficient importance to cause the proposition of a constitutional convention to be submitted to the people in 1835. The act providing for this convention made the county the basis of representation in the convention. OIt was so evident that the frontier Democratic counties would be in control that the Whigs and

(1) Laws of Missouri, 1843, page 9.

(2) House Journal, $1844-45$, pages 296-297. Senate Journal, $1844-45$, pages 99,100 , and $108 .^{2}$ 

more populous counties defeated the proposal by a vote of two to one. (I) The question of a convention continued to be agitated until the legislature of 1842-43 again submitted the proposition to be voted on at the August election of 1844 . This act made the senatorial district the basis of representation in the convention. The Democratic leaders who at heart were probably opposed to a convention soon saw that it would be impossible to defeat it and, therefore, came out for it. The vote for the convention was 37426 while that against it was only 13750. (2)

A special election was alled, delegates were elected, and the convention met in the fall of 1845. A new constitution was drafted and submitted to the people at the next general election in August 1846. It corrected the problem of representation by creating legislative districts of the thinly populated counties, but the constitution was rejected by a majority of about 10000.(3) Although Benton had been (I) M1ssour1 Intelligencer, Sept.12,1835.

(2) Statesman. INov.29,1844.

(3) There seems to have been three distinct reasons for the opposition to the proposed constitution. The article on banking and corporations forbad the creation of any corporation which could issue a circulating medium; provided that all corporation charters (municlpal, eduoational and charitable excepted) had to contain a clause giving the legislature the right to repeal and annul the charter by a majority vote; and also provided that stockholders in all private corporations (educational and charitable excepted) should be responsible in their individual and private capacity for all debts and liabilities of every kind incurred by such corporation. This probably accounts for the strong negative vote of St. Louls In spite of the fact that St. Louis would have been very much benefitted by the provision for the reapportionment of rep- 

decidedly involved in the question of calling a convention the Benton Ant1-Benton fight did not in any way enter into the question of the adoption or rejection of the new constitution.

The question of districting the state for the purpose of olecting members to Congress came to be of equal, if not greater, importance than that of a constitutional convention. The Thig Congress passed on act, approved June 25, 1842, regulating the election of congressmen. This act provided that in each state the state legiglature should divide the state into as many districts as the state had representatives in Congress, and that resentation. The article on education provided that the proceods of 500000 acres of land which had been given to the state by the national government for internal improvement should be used instead for educational purposes. This clause accounts for the strong opposition of the people of the Osage and Grand river counties who expected to be directiy benefitted by the internal improvement projects dependent upon the public land grant. The article on apportionment of representation in the lower house of the General Assembly was the one of most vital significance and the one upon which the most determined fight was made. It provided for representative districts instead of the county as a basis of apportionment of representation. However, each county which had a free white population equal to three fifths of a ratio to be obtained by dividing the entire population by one hundred was to be a representative district. The practical effect of this. clause would have been to take away individual representation from all the frontier counties and group them in representative districts. The speeches and newspaper discussions show that this question of apportionment was the paramount is sue of the campaign, both in the frontier and the central counties. The appended map shows how decidedly the frontier counties opposed the adoption of the constitution. 


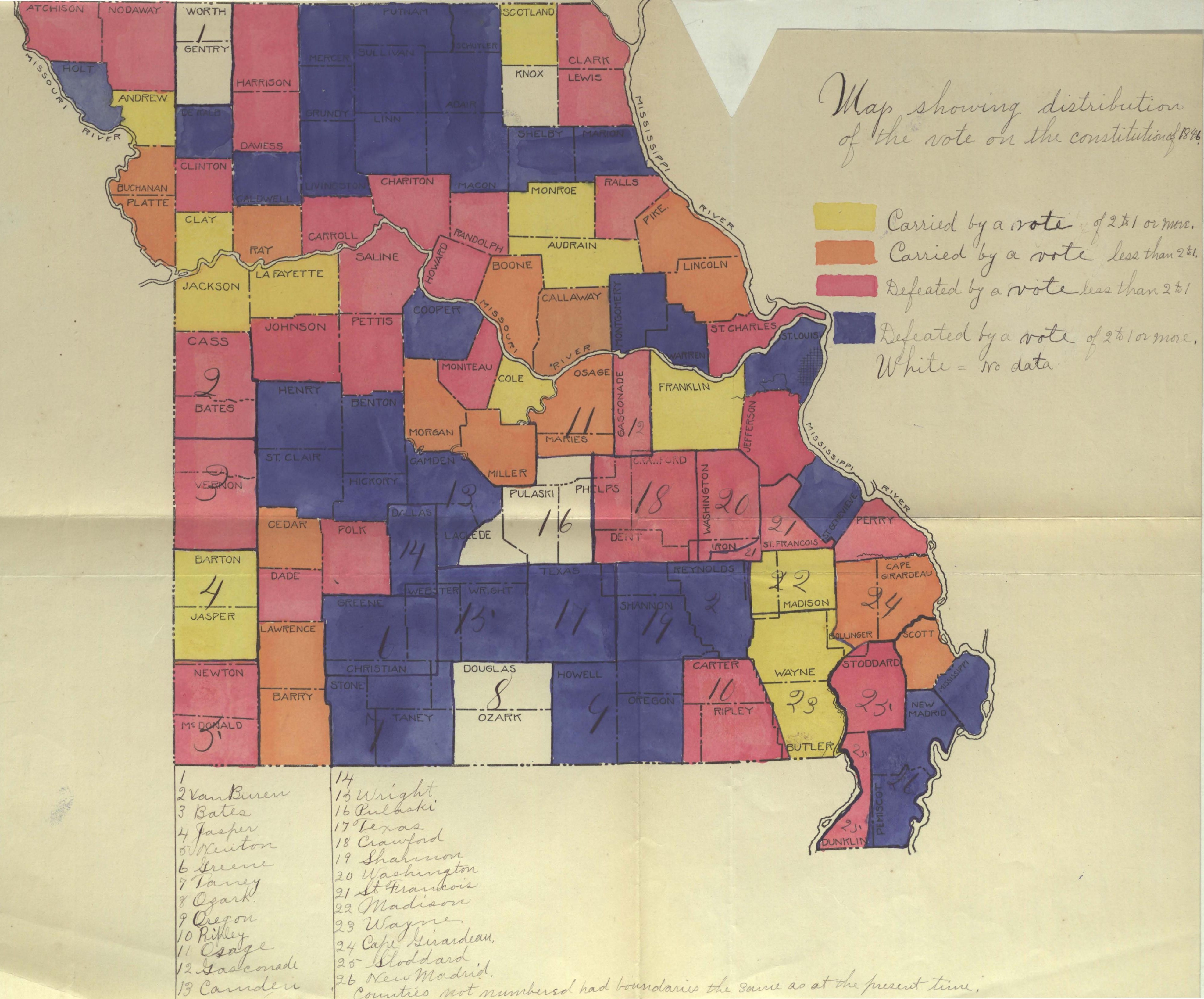



one congressman should be elected from each district.

Missouri had been electing by general ticket. The state had been entitled to only two members until 1842 when the number was increased to five. The greater part of the state officers and congressman had been residents of the central part of the state. This was the oldest and most thickly settled portion of the state, lexcept st. Iouls which was a. Whig city in a Democratic state and did not get many of the state officlals) and it would naturally be expected to furnish a large proportion of the officials. In the central counties the sentiment was very strong against the district system. The Democratic leaders urged that the state should not be hampered by the national government in the choice of 1ts representatives, but that it should be free to choose the most experienced and best qualified men it had. The fact that these experienced and qualified men lived in the central part of the state was not mentioned in their arguments. But the Democrats of the border counties never forgot that, "experienced and best qualified men," generally meant men who lived in the central part of the state, and they thought that the frontier counties should have their share of the officials. The Jefferson Inquirer argued that a demecrat was a democrat and that the state should have the services of 1 ts best men irrespective of their place of residence. (I)

(1) Jefferson Inquirer, Aug. 25,1842 . Ibid. Feb.23, 1843 . 

Th1s in general was the sentiment of the office holders. The strong sentiment of the democrats of the bordering counties, of the state in favor of the distriot system was expressed by their newapapers. The Ozark Eagle at Springfield in the southwest, The Platte Eagle and The Ilberty Banner in the northwest, The Missour1 Reporter of St.Iouls, The Missour1 Register of Boonville, and the Glasgow Pilot, all Democratic papers, favored distrioting the state.

The Whigs were in favor of the district system because from a national point of view it was a Whig measure, and then, if the state were districted they might get a congressman, while there was no chance to elect one if the general ticket plan of electing members to Congress were continued. These reasons, which caused the Whig party to favor the district plan, would naturally cause the Democratic party to oppose it. o In. the Democratic convention of 1842 the feeling of the frontier counties was so strong on the subject that the convention divided the state into distriots for the purpose of nominating candidates for Congresg.(1)

The districting of the state was one of the leading questions during the legislature of 1842-43. The Senate passed a districting bill by a vote of two to one, a bill which the House refused to pass, but instead passed one which provided for the election of five members to Congress by the gere ral 

ticket plan at the election of 1844. The Senate accepted the House measure. (1) During the fall of 1843 and the spring of 1844 the sentiment of the people as a whole became so strong for the district system that in practically all of the Democratic county conventions a resoltion favoring it was voted on and in many cases carried. In Platte county the resolution proposed a compromise by favoring the nomination of candidates for Congress by districts and their election by general ticket. (2) This was a safe proposition for the Democrats and was seized upon as a solution of the question by many, both of those who had favored and those who had opposed districting. But the discussion had gone too far. The district system had appealed to the people's sense of fairness and the Democratic press and leaders changed front on the question in $1844 .{ }^{\circ}$ They then said that the district plan was the fairest and best plan and that they had only opposed it as a matter of principle in opposing federal interference in state affairs; that the position of Missouri had been fully vindicated when her delegatioh of 1842 elected by the general ticket plan had been admitted to Congress. (3) A districting measure was passed by a Democratic legislature in 1844. (4)

(I) Statesman, Feb.24,1843.

(2) Platte Eagàe. Quoted in Jefferson Inquirer.Sept.21,1843

(3) Jefferson Inquirer, Dec. 7,1844.

(4) Revised Statutes of Missouri, 1845, pages 213 and 214. 

These issues of a new constitution and of districting the state are of interest in this study because Benton was practically compelled to take the unpopular side of both questions. His sentiment against paper currency and state banks of is sue was so strong that upon that question alone, so far as his speeches or letters show he was opposed to calling a constitutional convention. No doubt his political theories as well as his sense of fairness would have caused him to favor a convention upon both the question of reapportionment and the judicial tenure, but he was afraid a convention would do away with the constitutional restrictions against banking.o In a letter to the Democratic committee of Clay County, dated August 16th 1843, he said, "The constitution of the state of Missouri places some restrictions on the legislative power over the creation of banks; they are not sufficient, but few as they are, the Paper Money Party, are looking to the contingency of a state convention to sweep them all away and lay the state open to the mad career of free and universal banking." (1) This statement indicates that he was opposed to a constitutional convention and gives his reasons, but there is no ovidence that he actively alded the opposition to a convention. The question of districting the state for the purpose of electing members to Congress was of greater importance, to the crowd of politicians who posed as Benton's friends, than the question of a constitutional convention. There is no ovidence that ei fur from a standpoint of principle or direct (I) Missouri Register, Oct.17,1843. 

personal interest, Benton opposed districting the state. In fact, the evidence points the other way. Districting as a political method was more Democratic than the general ticket plan of electing congressmen. Benton was a typical western Democrat and from principle should have favored the district plan. His enemies claimed that he had favored that principle and had changed front. For proof they quoted Benton's report of 1826 in favor of cholce of electors by districts. (1) - Penn, editor of the Missouri Reporter, in his letters to Benton sa1d, 'In your report of 1826 in favor of the cholce of electors by districts, you furnieh an argument against the general ticket system, to a great extent applicable to the election of representatives to Congress, you say, 'In election by general ticket the candidates are presented to the people en mass; etc. you also state that the ticket bearing their names ia sent forth to the people to be voted for by many who know them not'. You assert that the election was intended to be a real and not a barren powor in the hands of the people',- showing that you regarded it as a comparatively barren power under the general ticket system". (2)

Why, then, did Benton oppose the district system? The only reasonable explanation is that he opposed it not because of the principle involved or because of his direct peroonal

(1) Th1rty Years' V1ew. Vol.I.pagea 78-80.

(2) Missouri Regiater.Nov.21; 1843.Penn's Letters. 

interests ( for he could have had none) but because of the personal intersts of his political associates in Missouri. Prominent among these political friends were Minor, Edwards, and Price of Cole County; C. F. Jackson, Dr.Iowry, Dr.Scott, Redman, and Rawlins of Howard County; Marmaduke and Dr. Penn of Saline County; and Sterling Price of Chariton County. All of these men lived in the central part of the state and if the state were districted would likely be thrown into one district and only one of them would have opportunity to go to congress. They therefore opposed the district system because of the ir personal interests. Benton was not concerned in the question personally except so far as his interests were bound up with those of his political associates, and as will be shown later did not come out on the district question until he was compelled to do so. 

CHAPIER III.

EARIY OPPOSTTIOIN TO BEIVTON - ORGAIIIZATIOIN OF FORCES.

After this analysis of political conditions and issues It is possible to discuss the origin and development of the so-called "Soft" faction in the Democratic party; a faction at first opposing the rigorous restrictions on banking and small notes, later advocating constitutional changes, but soon developing into the open personal attack on Benton which Is the subject of this study.

After the action of the Bank of Mis souri of Novemeber 12, 1839, refusing to receive or pay out the currency of suspended banks, the excitement in st. Louis mun high for several days and uncertainty prevailed everywhere: business was almost suspended until the readjustment to the new conditions could be made, deposits were withdrawn from the Bank of Missour $i$ and placed with the various companies rapidly taking the place the Bank had formerly occupied, the people were urged to deposit all the money they could possibly spare in order that sufficient currency for business purposes might be available. (I) The Whig press was especially active in the agitation. The Democratic organ, the Argus, sustained the Bank in its action. The Bank was a partisan ingtitution. Its president and the majority of the directors were Democrats, elected by the Democratic legislature, and naturally felt in some

(1) St.Louig Republican, Jan. 28, 1840. 

degree responsible to the body which elected them. One of these directorg, A.R.Corbin, was proprietor of the Argus. On Novemeber 20,1839, just a few days after the Bank's currenoy resolution, Corbin sold the Argus to A.J.Davis, who seoms to have been a highly respected citizen. The Argus continued its policy of defense of the Bank's action, and probably with more effectiveness since its proprietor was not a director of the Bank. Thus the Bank's action and the problemg growing out of it were congidered by afl to be political questions. The excitement, uncertainty, and business depression were used by the Whigs as political capital.

The ofty election in the spring of 1840 gave the first opportunity for the Whigg to turn the popular indignation against the Bank to political advantage. From the latter part of January until after the April election the daily Republican usually contained from a half column to two columns condemning the Bank or attacking the Democratic party on some phase of the ourrenoy question. The Redman currency bills were declared to be the issue of the contest. (I) The Republican in an editorial headed "Circuit Attorner", said, "Whigs, remember there are but two candidates for Circuit Attorney in the field to-day, John Bent,Whig, and Thos.B. Hudson, Locofoco. Remember that Col. Benton is determined to pass his currency bill at the next session of the legislature, and just reflect how you may feel under the prosecution of Irocofoco court, for the (I) St. Louis Ropablican, March 13,1840. 

violation of a Iocofoco law. It is too late to complain when the injury is accomplised. (1)

The Democrats conducted an active campaign in defense of the Bank and against depreciated currency. John Smith,president of the Bank, took a prominent part, and was chairman at a Democratic rally, at which N.Rainey,ex-governor of Iowa, and Thos.B.Hudson, both prominent later in the soft faction, spoke. (2) The Whigs elected their entire ticket by a good majority. It was during this campaign before the city election of 1840, that the first defection from the Democratic ranks was noticeable. Mr. B. Iawhead, a well known Democrat, adaressed a Whig meeting. Discussing his defection the Republican said, "But a short time since he was the main plilar of the administration. He was the owner and chief support of the Argus, and had probably rendered the administration more service than any other individual citizen. He has come boldly out againt the measures of his party". (3)

By May 1840 enough Democrats in St. Louis had become dissatigfied with the currency policy of the Democratic party to hold public meetings and advocate a more liberal banking policy. They were designated the "Bank Democrats". The Republican in describing one of these meetings said, "A meeting of the Bank Democrats was called for Monday night. The Anti-bank Democrats turned out

(I) St. Louis Republican, Reb.11, 1840. For discussion of currency bills see pp.12-17.

(2) St. Iouis Republican, March 25,1840.

(3) Ibid. March 18,1840. 

in force and the crowd was divided about equally, Darnes and Iawhead, favoring a National Bank and Riley and Trotter opposing- Hudson and Rainey would not respond." (I) The Argus refused to publish the proceedings of this meeting. William P. Darnes, one of the speakers, was secretary of the meeting. Edwards in his "Great West" described Darnes as a respectable citizen, (2) and the Republican commended him very highly and said, "This movement created consternation in the ranks of the party and having failed in their attempts to bribe Darnes they commenced to abuse and slander him." (3) Darnes wrote Davis, proprietor of the Argus, and asked if he was referred to by certain articles which had appeared in the Argus. His letter was returned to him without reply and the next day made public in the Argus. Soon after, Darnes met Davis on the street, and a fight followed in which Davis was killed. Darnes' trial came off in November of the same year and he was fined five hundred dollars (4) After Davis' death A.R.Corbin soon became propiretor of the Argus for the second time.

In the summer of 1840 when Benton returned from Washington he seems to have taken some part in the discussion of local political affaits. The Reptblican said, "The Colonel finds,'city expenditure', 'additional courthouses' 'spurious banking', 'small notes', and last though by no means least 'recreant Demo(I) St.Iouis Republican, May 27,1840 .

(2) Edwards, "Great West", page 370.

(3) St. Louis Republican, June 11, 1840.

(4) Edwards, Great West, page 371. 

crats'. The burden of his song relates to city expenditures and unoonstitutional, spurious banking which is carried on within the city". (I) The above expressions appear to have been taken from a speech which Benton made just before his departure, according to the Republican, "for the upper country for the purpose of winding up the legislature for another jear, should it not be incompatible with his other engagements. (2)

Benton arrived at Jefferson City in the early part of october and on the 8 th addressed a large delegate convention, the great rally of the presidential campaign. (3) This speech was chiefly upon the currency question and was one of Benton's great speeches upon that subject. Three years later when the conflict between the Softs and the Hards had become well developed this speech was published by the Jeffergon Inquirer for campaign purposes (4) Benton said, "The currency question is the great question of the age". Then he gave a brief history of the currency of the United States. He said that those who had struck down the second Bank of the United states had put in its place the constitutional currency, gold and silver; that in order to accomplish this a number (1) St.Iouis Republican, Sept.10,1840.

(2) St.Iouis Republican, Sept.30,1840.

(3) This convention, like many other rallies of the period, was a real delegate convention. County meetings had been held and delegates appointed to attend. It was not a nominating convention and seems to have had no work to do beyond listening to speeches, stirring up enthusiasm, and appointing a committee to issue an address to the public.

(8) Jeffergon Inquirer, Aug. 31, 1843. Benton very likely had his 1840 currenoy speech reprinted at that time as an expression of his sentiments. At any rate he had just visited Jefferson City and was atili in the central part of the state at the time of its publication. 

of acts had been passed, namely: the repeal of the act of 1819 against the circulation of forelgn silver, the act correcting the ratio between silver and gold, the act creating branch United States mints, the act which excluded small notes - all under twenty dollars - from the receipts and disbursements of the government, and the act creating a United States treasury. But yet other meagures were necessary to complete the great object. One was to suppress all paper money under twenty dollars. (I) This had been attempted, but had not yet been accomplished. He continued, "Ift every state suppress within its own limits the circulation of all paper under twenty dollars. I repeat 1t, the currency question is the great question of the age; it absorba and swallows up every other; the Democracy must purify and protect it; they must save labor, industry and comerce, from the depredations of depreciated paper; they must stop the banks from suspending when they please, and resuming when they please; they must reduce corporations as well as individuals to the subordination of the law; they must maintain the specie circulation; they must do all these things or surrender the government both state and federal. They will lose all power if they do not and what is more they will deserve to lose it." This speech coming as it did just before the meeting of the General Assembly which convened the third Monday in November became a keynote to the polloy of the legislature.

(1) Benton's currency speech, Inquirer,Aug.31,1843. 

Col. Benton remained in Jefferson City and vicinity until he had to start to Washington if he were to get there for the opening of Congress. His political opponents claimed that he was using undue influence with the state legislature, outlining its work, directing its leaders, making slates, etc. The Republioan of November 18, said, that Col. Benton was in Jeffers on City for the purpose of organizing the legislature.

The legislative program upon the currency and related problems was quite ambitious. The course of the Bank in repudiating the notes of suspended banks was approved by a resolution (1) winich was passed by a large majority, and legislative sanction was also indicated by reelecting John Smith president of the Bank. (2) A resolution providing for a commlttee to investigate the business of the insurance companieg was pasged. (3) A law was enacted taxing brokers and exchange dealers on all bills, notes, etc. handled for others than citizens of the state, also a tax on all notes for money loaned and also upon property or money held in trust for citizens of other states. (4) The Redman currency bill was passed in the House and failed on passage in the Senate by only one vote.(5) But probably the most important of all these measures in 1 tg immediate offect was an act amending the act of incorporation for St.Louis. (6)
(1) Jefferson Inquirer, Dec.17,1840.
(2) House Journal 1840 pageg $116-118$.
(3) Jeffergon Inquirer, Dec.24,1840.
(4) Ibid., March 11,1841 .
(5) Missouri Register, Feb.25,1841.
(6) Laws of Missouri, 1840-41, pages 129-142. 

Th1s act was introduced by Redman, of Howard County, and pushed though over the protest of the delegation from St. Iouis. Circumstances attending the discussion of the act produced considerable feeling in st. Louls. The correspondent of the Republican condemned the act in strong terms, called it an outrage,etc, and said that it had been sent to Jefferson City already prepared.(1) For this he was expolled from the privilege of going within the bar of the House. (2) The Republican made as much capital as possible out of what it called the tyranny of the logislature in attempting to prevent the freedom of the press. The other newspapers of St.Iouis allowed it the use of their correspondence, and all St.Louls papers Whig and Democratic alike condemned the action of the legislature. (3) Thus the antagonIsm between St. Iouis and the state government was intensified, and public opinion in St. Iouis tended to become unified concerning all subjects upon which there was a difference of opinion between the city interests and the central government.

The most important features of this st. Iouls incorporation act were: the change of ward boundary lines, which was favoreble to the Democrats, the removal, of all property qualifications for suffrage in city elections, the removal of property qualifications for holding city offices, and the change of the offices of register,
(1) St.Iouis Republican,
(2) Ibid.,
Jan. $1,1841$.
(3) Ibod.
Jan. 1I, 1841.
Jan.12, 1841. 

auditor, and city marshall from appointive to elective positions.(I) These measures were all democratic in nature or in the direct interests of the Democratic party in st. Louis.

The total effect of this legislative action and the discussions growing out of it $1_{\text {Is }}$ the st. Louis gituation appear to have been peculiar and in some ways unexpected. The removal of the propetty qualification for suffrage enlarged the city electorate and favored the Democratic party. The change of the ward boundaries effected a gerrymander so evident that in two wards of the city no Whig candidates for the city council were nominated, and in two other wards no Democratic candidates were placed in the field, while one ward was doubtful, and in this there was a spirited fight.(2)) Corbin the Democratic candidate and editor of the Argus was elected to the city council by a small majority. Commenting on Corbin's election the Republican said, "Other circumstances than mere party strength elected him and we hope that other than mere party considerations" will govern his action. (3) The Jefferson Inquirer quoted the above comment of the Republican and in an editorial on the subject inferred that the "other circumstances" had reference to the currency problems (4)

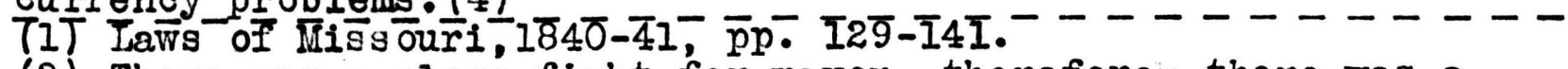
(2) There was a close fight for mayor, therefore, there was a full vote in all the wards of the city. The vote cast was as follows:-first ward 79 , second ward 492, third ward 617, fourth ward 500, fifth ward 727. In the first and second vards there were no Whig candidates for the council, in the third and fourth wards no Democratic candidates and in the fifth there was a contest. The Republican suggested that the governor call the legislature in extra session and have the first ward which cast 79 votes divided into a half dozen wards and then there could be no question of Democratic control in the city council.

(3) St. Iouis Republican, ApriI 7,1841. 

The Argus, in December 1840, had began to favor editorialiy a limited partnership bill which was then pending in the leglslature, and was attacked by the Inquirer for favoring irresponsible corporations. The Inquirer said, "If such a measure can receive the approbation, support, or even countenance of any true democrat, then we ask such to review his profession of polcity, and see how it corresponds with his principles. We say purge us from such democracy- thats all". (I) The criticism of the Inquirer did not seem to affeat the policy of the Argus in the least. Soon after in an editorial it gaid, "The loaning of money itself, buying or selling a bill of exchange, or receiving money on deposit does not constitute banking unless a person or corporation makes a distinctive business of one or all of them." (2) This definttion of banking would clearly exclude the corporations of St.Ioufs, and the Argus was again attackod by the Inquirer_for favoring corporations. J.J.Iowery, president of the branch bank at Fayette, also replied to dorbin'g editorial in the Boonglick Demoorat published at Fayette. Corbin replied to Lowery's article in a long letter in which he professed great respect for Dr. Iowery as an older man and a Democrat of longer standing than himgelf, but stood by his definition of banking, and also sald that while he was against the 1s sue of small notes, yet they should be excluded "in (1) Jefferson Inquirer, Dec.17, 1840.

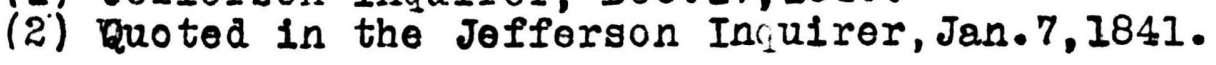



such manner as not to interfere, 1st, with the liberty of the citizen, 2nd, with the principles of free trade as defined by Jefferson,or 3rd, to create distinctions among men by prescribing test oaths to some while exempting others therefrom." (1) He also defended the corporations for recelving deposits and lending money. From the above controversy of the Argus with two of the leading Democratic papers of the central part of the state it is clear that the St.Iouis paper was shifting its position on the currency and banking problems in general.

The Argug was not alone among $S t$. Louis Democrats in this movement. The existence of the faction lead by Lawhead and Darnes, and the allusions of Col.Benton to "recreat democrats" has already been noted. Soon after the legislature of 1840-4I adjourned the direotors of the Bank of Missouri rescinded the order of llo vember 12,1839, and from that time on the Bank dealt in the paper currency of other banks. (2) There seemed to be a gradual development of agreement among $S t$. Louis people upon the problems connected with the currency question, alohg with the rise of an antagonistic spirit towards the "up state" section. The Republican, which had always as a matter of party policy opposed the Bank of Missouri, in January, 1841, complimented the new Board of Directors very highly upon the excellent (1) Corbin's Ietter, Published in the Inquirer, Feb.11,1841. (2) Republican, March 13,1841. 

atart they had made in the management of the institution. (I) Iater it heartily approved of tho course of the Bank in rescinding the order concerning depreciated currency, and quotod a long article from the Argus on the insurance companies, endorsed it fully, and complimented the editor for his good sense; but noted the fact that it was a complete "contrast to the principles and sentiments heretofore avowed by the same press, and re-echoed by nearly every leader of the Van Buren party." (2)

The attitude of many Democrats in st.Iouis was probably Iike that of General Miller the Democratic postmaster, evidently not a man who had been unfriendly to Benton or he could not have beld that position. When he ras removed by the Tyler administration in the summer of 1841, the Inquirer commented thus, "We are not afraid to say that a respectable number of Democrats (not oil and water men) were ready to sanction the removal of General Miller at any time during the past two years, not that he was either a drunkard or a gambler, but that among other reasons he was suspected of being neither a Thig nor a Democrat". (3)

As was to be expected, when the Argug took 1ts new position on the banking questions and refused to heed the criticisms of the Democratic press of the state, the Inguirer made (I) Republican, Jan. 7, 1841.

(2) St.Ioula Republioan, Jan.6, 1841 .

(3) Jefferson Inquirer, June 24,1841 . 

a series of attacks upon 1 ts editor for having a squinting toward bank aristocracy, (1) for desiring to divide the Democratic pity, (2) because he was a traitor to Democracy and thereby secured eleotion to the clty council of the Whig oity of St.Lop1s. (3) It also said in the is sue of August 26, 1841, "Although the Argus hangs on the name of Col.Benton, our frlends will ere long find, what wo lest winter proclaimed, that he is an enemy in disguise." As early as April,1841, the Inquirer had suggested the need of another Democratic papor in St.Iouls, in the following language, "Our candid and deliberate opinion is that the Democracy of St. Louls and the whole state, owe it to thomselves, to establish another press in the city, one in which the party can have confidence, that will speak their sentiments and maintain their principles". (4) This suggestion was approved by most of the Democratic press of the state.

On the other hand the Argus attaoked Governor Reynolds, Dr. Lowery, the Inquirer, the Boonsliok Democrat, and others as the "Central Clique". Its general course was one that tended to widen the breach and increase the feeling that already existed between the city and the central government. The Republican in commenting on the situation said, "On recent occasions the editor (Corbin) has thought proper to act and speak aocording to the dictates of reason and common sense In relation to our local institutions, and this act of self-
(I) Jefferson Inquirer, Daroh 25, 1841.
(2) Ibic.,
(3) Ib1d.,
April 1, 1841.
(4) Ib1d., April 15,1841. Aug. 26, 1841. 

judgment is amply sufficient to dam him with the leaders of his party. We are well aware that it is very important that he conciliate and make peace with the great head, the commander-in-chief of Missourl Looofocoism. Corbin has got himself in the mire and if the Colonel comes not to his rescue he is irretrievably swamped with the Locofoco leaders." (1)

Finally in the fall of 1841 Corbin sold the Argus to Shadrick Penn Jr. who changed its name to the Missouri Reporter. Penn was an editor of long experience, who had moved from Loulsville, Kentucky to st.Louls. The Reporter was welcomed by the Democratic press of the state. Its prospectus was noticed and Democrats in all parts of the state were urged to support it because of the need of a pure Democratic paper in St.Iouis.

Political motives and plans are difficult to discern even when all published material is accessible, for politicans do not publish their plans; but judging from the conditions in St. Louls and from the results which followed as well as the later aotions and writings of Democratic leaders there seems to have been adopted, on the part of the St. Iouis democracy, a definite polioy of concliation toward the up-state democracy, and at the same time a careful selection of gafe men for office. And safe men in st. Louls meant men with liberal 1deas on ourrenoy, corporations and banking. The Reporter 

cultivated friendy relations with the Democratic press of the state and carefully avoided any reference to the Central Clique. Penn even went so far as to publicly repudiate Corbin who was a candidate for Congress. He refused to publish an article for a correspondent lauding Corbin and after it had been published by another paper in the city, came out with a long editorsal stating that he had been asked to publish the article and had refused. (1) The Inquirer copied this editorial and praised the Reporter for its sound democracy. Among other good things it attributed to Penn's influence was the cessation of factional, strife in the city democracy. It said that the nominations of delegates to the state convention had been made without any friction which was an unusual thing for St. Iouis Democrats. (2)

The currency question seemed to drop out of politics so far as St.Louls was concerned. Nativism sprang up there and the Whig party became hopelessly divided. The Democrats carried the city in April, 1842, electing the mayor, and a majority of the city council, and in August they also elected one senator and five out of seven of the representatives to the state legislature. This was but little more than three months after the publication of the Reporter had commenced. Penn in later articles inferred that the Reporter had been (1) Jefferson Inquirer, Jan. 20,1841. (2) Ibid., 

the means of securing the Democratic victory in the city, normally Whig by from 500 to 800 majority. (1) No doubt he did contribute to the victory, but the enlargement of the electorate and the rise of Nativeism were the chief causes, and what Penn did do he must have done by going with and giving expression to the popular sentiments in the city.

Such a victory could be won only by selecting men who could be trusted to reflect the popular sentiment toward the most vital public question of the day- that of banking. In St. Louis, that was the side of liberal construction of the banking and corporation laws. A city that had become as thoroughly aroused against the policy of the Hards as St. Louis had, that had rewarded Corbin for his conflict with the Central Clique by electing him to the council, that had elected a Circuit Attorney upon a policy of non-enforcement of the banking and corporation laws, that had a Postmaster,certainly a Benton man when appointed- of whom it was said by the Hards " that it could not be told whether he was a Whig or a Democrat", most surely would not have elected Democrats unless it d been certain of the personal opinions on currehoy questions of those whom it was electing. Proof that these men were selected with a view to their opinions on the banking question is not only found in the fact that probably no other kind of men could have carried St. Iouis, but also (1) (1) Penn's Iotters to Benton, Missouri Register, Nov.14, 1843. 

in the fact that both the men themselves and the issues upon which they were elected were displeasing to Colonel Benton. (I) There was only one standard by which these men, being Democrats, were likely to have been condemned by Benton and that was with respect to their views upon banking. But that was the important question both to Benton and to st. Louis. It was the one subject upon which the legislature could touch St. Louis most vitally. A Democratic delegation with liberal views on banking and currency could be of greater service to St. Iouis in a Democratic legislature than could a Whig delegation. The opportunity for this service came in the legislature of 1842-43 on the election of the President and directors of the Bank. As noted above, soon after the legislature adjourned in 1841, the Bank by a vote of its directors decided to receive deposits of depreciated currency. The Hard money Democrats of the state were opposed to that policy of the Bank and decided to elect Dr.Penn, of Howard County, a Hard Democrat whom they were sure they could trust, to the presidency of the Bank. (2) The St.Louis Democrats were very much averse to a (1) Penn in his letters to Benton published in the Missouri Register of November 14, 1843, said, "On your visit to this city, some sixty days after the August election of 1842, I soon learned that you were dissatisfied; that, in your estimation, every thing was done wrong; that improper poitions had been taken in the oon tests preceeding the elections mentioned; that you disapproved of the course of the city administration, and believed that a proper selection of men had not been made to represent $\mathrm{St.}$. Iouis County and City in the legislature."

(2) Dr.Penn must not be confused with Shadrick Penn, editor of the Reporter. Dr.Penn was a Democratic politican of Saline County and a leading member of the Central Clique. I shall refer to him as Dr.Penn and to the editor as Penn. 

Hard Democrat from the country being made president of the Bank and determined to elect Kennett, one of the directors for the preceding two years. He had voted in favor of receiving deposits of depreciated currency, and had been elected to the legislature at the next election. (1)

The St.Louis delegation under the leadership of Thos.B. Huds on ran Kennett for President of the Bank and elected him by a good majority in spite of all that C.F. Jackson and the Central Clique could do. Hudson seems to have forced the fighting immediately after the legislature oonvened. There was an agreement made between the friends of Dr.Penn and Kennett to settle the question of their candidacy in a caucus of the Democratic members. Both candidates agreed to abide by the results of the caucus. (2) Just before the caucus meeting Mr. Whipple, a Hard, offered a resolution calling for a special report of the investigating comittee which Governor Reynolds, in accordance with a provision of the Bank charter, had previously appointed to investigate the affairs of the Bank. (3)

(1) Jefferson Incuirer, Dec. 15, 1842.

(2) Jefferson Inquirer, Dec.,15, 1842.

(3) Mr. Whipple's resolutions House Journal of 1842 pages 92 \&. 93 Resolved, That the committee appointed by his Excellency the Governor, to examine tnto the condition of the Bank, furnish the House with any information in their possession, or within their knowledge whe ther written or verbal, whereby reasons were given by any director or directors of the institution, for voting for or against, or protesting against the resolution adopted by the Board on the 12th of March 1841, for receiving depreciated paper on deposit, and for the payment of debts due the Bank. Resolved, That the committee be requested to state whether in their opinion any information proper to be communicated to the Iegislature, has been withheld by the officers of the Bank. 

The order of the Board of directors of March 12,1841, for receiving depreciated paper on deposit was to be the subject of the special report. The friends of Kennett, evidently, did not dare to vote against the resolution and it passed without opposition. C.F.Jackson, a Hard, introduced a series of resolutions calling for a very detailed and extensive report from the cashier of the Bank, After an amendment by Hudson, Soft, of St.Iouls, to make the resolution applicable to the Branch Bank at Fayette (there were two other branches which Huds on did not include in his amendment) the resolution with the amendment passed by a practically unanimous vote. (I)

The investigating committee's report cast such reflections upon the management of the Bank and by inference upon Kennett who was a director, that his friends refused to go into caucus. Instead they determined to push his election in the open House where they could have the Whig aupport. (2) On December 5, the day set for the election of the President of the Bank, after the two Houses had assembled and Hudson had placed Kennett in nomination, Jackson offered a resolution to postpone the election until the second Monday in January in order to give the Assembly time to receive the report of the cashier requested by the resolution of December 3rd. Wells, of Warren County, rose to a point of order. The speaker, Sterling Price, who was a Hard, (1) House Journal of 1842 , page 94. (2) Jeffers on Inquirer, Dec., 15, 1842. 

decided the resolution in order. (1) Jackson's motive for introducing the resolution was assailed by Hudson and others. "It was charged that he introduced them for the sole purpose of injuring the prospects and preventing the election of $\mathrm{Mr}$.Kennett (2) Jackson's resolutions were voted down in foint Assembly by a vote of 42 ayes and 86 nays.

The first real line up of the factions is shown in this vote. In previous legislatures there had been a few soft Democrats, but the Whigs had always assumed the leadership of the opposition to the currency measures of the Hard Democrats and the Softs had voted with the Whigs. Here for the first time Hudson and the Soft Democrats take the leadership against Jacks on and the Hards and the Whigs votedwith the Softs. An analysis of the vote shows nearly all of those, who were in the Assembly and who became leaders of the Hards in the campaign of 1844, voting with Jackson, and but one man who became a leader of the Softs so voting. Among those voting with Jacks on who became noted as Hards were Fort, Gilliam, Massey, Rawlins of Howard,Wolfskill, Minor of Cole, Scott, Shields, Wheaton, Whipple and Sterling Price. Among those voting with Huds on who were later recognized as leaders of the Softs were Boggs, Ellis, Campbell of Dunklin, Hudspeth, Young and English. The vote on these resolutions indicated that Hudson had his forces much better organized than Jackson.

(1) House Journal,pp 100 and 101.

(2) Jefferson Inquirer, Dec.15, 1842. 

After this defeat the Hards did not put Dr.Penn in nomination, but put up Robert Campbell of St.Iouis. Kennett was elected by a vote of 91 to 38. Most of the Hards who had previously voted with Jackson voted for Campbell, but some scattering votes were cast and five of them went over to Kennett.(I)

This was the first definite conflict between the Hards, led by a group of men dabbed by their opponents the "Central Clique" and the Softs among whose leaders were Hudson of St.Louis, English of Cape Girardeau, Boggs of Jackson County, Ellis of Clinton County, and Fells of Iincoln County. Conspicuous among the leaders of the Central Clique were C.F. Jackson, J. J.Lowery, Dr.Scott,Redman, and Governor Reynolds all of Howard County; and in addition to these, sometimes called the Fayette clique, Dr.Penn,sterling Price, and liarmaduke should be mentioned. The Jefferson Inquirer became the champion of the Hards and the Missouri Roporter of St. Iouis was the leading newspaper of the Softs.

The Reporter now came out openly and condemned the Central Clique in even stronger terms than the Argug had done. Penn declared that a few men in the central part of the state were trying to mun the affairs of the whole state, and were parceling out the offices among themselveg.(2) Until the fight over the election of a bank president the Inquirer and the Reporter had (1) House Journal of 1840, page 102.

(2) Quotation from the Reporter in the Inquirer, Dec.15,1842. 

maintained friendly relations. The Inquirer had reproved the Reporter for its kindly regards for Campbell who was running independently for Congress, but it was careful and friendly in its methods. (1) As late as November, 1842, the Inquirer found a passage in the Reporter on the currency question that it could quote with approval. (2)

After the Bank fight opened stinging articles appeared in both papers weekly. At first they purported to be written by correspondents, but on December 29, the Inquirer issued a formal declaration of war in which it said, "You have commenced the war and we shall defend to the last ditch".(3) In the next issue (1) Jefferson Inquirer, July 28,1842. John P.Campbell of Greene County, was a candidate for Congress under rather peculiar circumstances. Before 1842 Missouri had been entitled to two representatives. The appotimnment bill was pending in Congress when the Democratic convention met in June, 1842. The bill had already passed the House and according to its provisions Missour 1 was entit led to seven representatives. The convention, therefore, nominated seven men for Congress. As a precaution in case the bill did not pass or was changed the convention by resolution decided that the nominees should draw for numbers, and in case of failure or change of the apportionment bill those beving the highest numbers were to be dropped until the number of nominees corresponded to the number of Congressmen to be elected. The apportionment bill was so amended in the Senate that Missouri's delegation was reduced from seven to five. Campbell had drawn number six and according to the resolution he was not a nominee of the convention after the apportionment bill became a law. Campbell, however, claimed that he had never consented to the arrangement and would not withdraw. He was strongly supporied by the Ozark Eagle published at Springfield and favorabiy mentioned by the Reporter.
(2) Jefferson
(3) Ibia.,
Nov. 10, 1842.
Dec. 29, 1842 . 

the Inquirer said, "War has been declared by the press of St. Iouis both Whig and Democratic, and it is a war in favor of small notes, against hard money; in fawor of shinplaster and swindling shops, against half eagles and Benton mint drops; and every member of the legislature who does not bow submission to the coalition will be marked for proscription at the next election. Their hate extends from Benton to every member who does not obey implicitly the commands of their st.Iouis masters. We say to the Democracy of the country every man to his post." (I)

The fight was now on in dead earnest. The Inquirer rang the changes on shinplaster, small notes, rag money, and corporations, and accused St. Iouis of trying to dictate to the whole state. (2) The Reporter with more skill attacked the Central Clique for its past dictation and its schemes for the future. It crowded to the front the issues of districting and a constitutional convention, and made a special point of hitting at Governor Reynolds at every opportunity. (3)

The Reporter had struck a popular chord in advocating districting and a constitutional convention. The blows of Penn and his followers were be ginning to tell. Something had to be done or the Hards would be overthrown. Col. Switzler, editor of the Statesman, a Whig paper, in commenting upon the Demooratic mass

(1) Jefferson Incuirer, Jan. 5,1843 .

(2) Jeffers on Incuirer, Jan.12, 17, ahd 25, 1843.

(3) Ibid., Feb. 2, 1843. 

meeting in Clinton County which had proposed David R. Atchison for governor said, "This will prove serious and annoying to the Central Clique", and referring to Penn, "He will either whip them into the open advocacy of his doctrines, or he will guillotine every mother's son of them from his excellency down". (I)

After the bank election the factional contest opened up as a newspaper fight. The Democratic press of the state began to take sides either with the Reporter and against the Central Clique, or tith the Inquirer and against a depreciated currency. New papers were started at strategic points by both factions and efforts were made by each to overthrow the presses of the other. Penn by shifting the issues from currency to the constitutional questions secured the support of several papers in the border of the state, The Soft press of the state included in addition to the Reporter, the Ozark Eagle published at Springfield, the Iiberty Banner in Clay County, the Grand River Chronicle at Chillicothe, the Osage Yeoman at Warsaw, the Glasgow Pilot, and the Missouri Register at Boonville. The unquestioned Hard papers who adhered to the Central Clique were the Jeffergon Inquirer, the Boonslick Democrat in Howard County, the Fayette Democrat in Howard County, the Paris Sentinel, the Western Missourian in Jackson County, the Boonville Argus and the Migsouri Standard (later the Missourian) published in st. Louis. The Platte Eagle was for districting but seemed to be in accord with the Central (1) Statesman, April 21,1843. 

Clique on other questions. Of the above named papers the Iiherty Banner and the Osage Yeoman, Soft, and the Missouri Standard and Boonvilie Argug, Hard, werc established during the jear of 1843; and the Paris Sentinel, the Boonslick Democrat, the Westefn Missourian, and the Missouri Standard, all Hard, failed during the same year. (I)

Such was the political condition in Missouri when Col. Benton arrived from Tashington in the summer of 1843, and threw the great weight of his influence into the contest on the side of the Hards. There is no evidence that he said anything in his public speeches concerning the factional contest, but he wrote letters for publication which placed him oquarely and openly in the fight against the Reporter, and the measures it advocated.

Benton arrived in st. Iouis sometime in June and it soon bocame known that he was opposed to Penn. The Republican 8aid, "The power of Benton has been gradually growing weaker in this state since Penn arrived. It is needless to point out the leaders of the two factions. Benton has Iong controlled the party of the state, but last winter he was completely defeated by Penn. The consequence has been to array Benton in open hostility to Penn and Benton does not hesitate to denounoe Penn as a traitor." (I)

During the summer Benton made a trip, as was his custom, to the central part of the state. He visited Jefferson City, Boonvilie, Warsaw, Glaggow, and probably other places, stayed a 

few days in each town and returned to st. Louis about the middle of September. Benton's favorite method of ampaigning was characteristic of the man. Soon after his arrival in a town the newspaper announced that Col. Benton was in town and during his visit would live at a certain hotel (giving the name) where he would be pleased to receive his friends. (1) It was cortainly at these private conferences that Benton did most of his work in directing Missouri Democracy, and his opponents claimed that he gave absolute order which had to be obeyed.

Benton followed this method on his summer trip of 1843 and did not announce his position publicly by either speeches or letters upon the question of districtine or a constitutional convention until after the Osage Yeoman, a Democratic paper published at Warsaw, announced in an editorial,August, 1843, that Benton, who had just visited Warsaw, was in favor of the district system. Benton, as soon as he saw the editorial made the following announcement, over his signature dated August 23, 1843, which was published and copied in practically all the papers of the state.

"Juatice to my political friends (against whom my imputed opinions are quoted) requires me to notice a statement in the Ogage Yeoman in which opinions are attributed to me which I never expressod, as that I was in favor of the district system(1) Jefferson Inquirer, Nov.3, 1842. 

that Col.Johnson would take the restern states,etc. The editor of the Yeoman has been misinformed and I deem it my duty to say so as an act of justice to my political friends, seeing the use which is made of this erroneous statement against them." (I) This statement makes it clear that Benton was not so much interested in the district system as he was in his political friends. He does not state that he is opposed to the system, simply that the editor of the Yeoman was mistaken in quoting him as favorable to it. His reason for making the announcement is not that he may show his opposition to the district system, but that he may do his duty in performing an act of justice to his political friends, against whom his imputed opinions had been used. This is all the part Benton took in the contest on the district question, so far as the records show, but from this time on his enemies had a great deal to say about his opposition to districting.

When Benton arrived in St. Iouis about the middle of September after this trip through the central counties he found a large amount of mail awaiting him. There were many invitations from County Committees and Committees of citizens of ntowns to visit their respective 2ocalities, to make addresses, to partake of public dinners given in his honor, etc. In replying to these letters Benton made suggestions concernIng the factional fight within the Democratic ranks which could (1) Statesman, Sept.1, 1843. 

leave no doubt in the minds of Penn and his followers as to Benton's attitude toward them. For instance in his Palmyra letter of September 16, declining an invitation to visit the city, he said, "Your allusions to insidious and disguised enemies of the party are just and true. I have long seen their designs such as you describe them; and time will soon verify all that you have said. But no matter. Underhanded enemies cannot flourish in Miss ouri. The spirit of the country is high, and requires an open foe, and a manly contest. To make war upon a party while professing to belong to it, - to undermine public men, while professing to support them,- to foment division while preaching union, - to kiss Tylerites and Whigs while biting Democrats, is a spcie of warfare of recent importation among us, and which can have but a brief existence in our generous clime." (I) Also under date of September 16; Benton wrote his letter to the Clay County committee (quoted in a previous chapter) in which he practically took a position against a constitutional convention because of the danger of sweeping away the restrictions against banking. (2)

A Hard Democratic paper which had been started in st.Louis in the spring of 1843, the Missouri Standard, had never attained sufficient circulation to make it effective. Benton and the Hard money faction started a new paper in its stead, The Missourian, under the management of Van Antwerp, an editor from 

Iowa. Benton, on September 18,1843, wrote a sirong letter of recommendation for Van Antwerp in which he said, "This paper is intended to be permanent in its establishment, general in its circulation and faithful in its conduct. The success of the Democratic cause, the protection of the policy under which the state has prospered**** requires such a paper and that it has eatablished in this city**** The safety of the cause requires such a paper and to establish and sustain it, the united exertion of the friends of the cause will be wanted.**** The firends of the cause in every county should make the case their own. They should take charge of subscription papers,and make it a point to obtain subscribers in every township, every neighborhood, and every postoffice in the state. With this view I enclose the within papers for yourself and friends, to obtain subscriptions; and as st. Iouis is not a locality favorab le to the support of a Democratic newspaper, the Country has to be relied upon, and the necessity for speedy action,prompt payments and punctual remittances can be seen by all." (I) This letter was published and widely copied by the press, both Whig and Democratic. The Missouri Register and the Statesman claimed that it was scattered broadcast over the state under Benton's frank. (2)

These letters together with Benton's statement in answer to the Osage Yeoman (quote above) declaring that the Yeoman was mistaken in quoting him as having favored districting etc put him at the head of the contest against the Softs, put new vigor into the Hards, caused a closer alignment, and brought Penn out

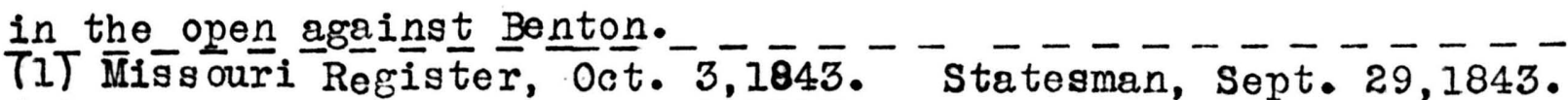
(2) M issouri Register, Dec. 18,1843. 

CHAPTER IV.

CONIEST FOR PARTY CONIROI.

Benton's emphatic support of the Hards and the Central Clique left the Softs no choice except submission or open opposition to Benton. The Softs, probably, at heart had been opposed to Benton for some time, but had dreaded the effect upon the public of an open breach with him. A few of the bolder ones among them had declared openly against his policies and it was no doubt true that some adhered to the Soft faction not because of their views upon the currency but because of their feeling of hatred to Benton whose speeches and well known principles upon the money question made him the logical leader of the Hards. (I)

The position of the ozark Eagle, it seems, is to be explained in this way. A deep seated antagonism to the Central Clique and to Benton in particular appears to have existed at Springfield earlier than anjwhere else in the state. The Patriot, a Whig paper published in Columbia, under date of June 2, 1842, quoted a rabid article against Benton and the Central Clique from the Ozark Eagle. In this article the editor of the Eagle declared that evidence of his independence of the Central clique could be found by reference to his files at any time for the past two years. As early as January, 1842, the Jefferson Inquirer severely criticised the Ozark Eagle for its attaks on the Central Clique. (2)
(I) Jeffers on Inquirer,
(2) Ibia.,
Jan. 5, 1843.
Jan.27, 1842 . 

In addition to Col.Benton's strong and open support of the Hards there was one other event which occurred in November, 1843, and which probably exercised a determining influence upon the contest. Dr.Iinn, Senator from Missouri and Colleague of Col. Benton, died and Governor Reynolds thus suddenly found at his disposal the office of United States Senator. The Northwest was at that time one of the most rapidly growing sections of the state and a strong anti-Central Clique and Soft sentiment existed there.(I) David R. Atchison, of Platte County, the most popular man of that section, from all the evidence, as will be shown later, a Soft and probably at heart an Anti-Benton man was appointed United States Senator to fill the vacancy caused by the death of Senator Iinn. In this appointment Governor Reynolds who was accused by the softs of being the he ad the Central Clique made it appear that there was no such organization by going to the border of the state and selecting a leader of the opposing faction for the higest position within the gift of the people of Missouri. More important than the general effect and appearance was the fact, that in this appointment Governor Reynolds spiked the guns of Atchison and his friends, and if he did not make them supporters of Benton he, at least, put them in a position where they could not afford to openly oppose him.

(1) Missouri Register, Nove. 14,1843. 

On October 24,1843, Penn, the editor of the Missouri Reporter began the real attack on Benton through the publication of a series of open letters to Benton. (1) He began by saying, "Your letters (2) recently published, viewed in connection with previous occurances, of the nature of wich the Democrats of the state are unapprised, impose upon me the duty of addressing you through the public press. Your detestation of a half concealed enemy cannot be more decided than my own; and it is impossible that you can feel more contempt for the selfish and deceitful partisan, or the professed Democrat who would blast the reputation of men of the same party, by insinuous, groundless charges or virulent denunciation. I greatly prefer 'an open foe and a manly contest'".

A brief account was then given by Penn, of his removel from Louisville Kentucky to St. Louis, of the launching of the Missouri Reporter, of his and Benton's early political career, of the St.Iouls City election in the spring of 1842, and of $\ldots$ the state election in the following August. Finally he launched into the factional fight at what he regarded as its beginning - the return of Benton from Washington in August 1842 . The Democrats in Missouri were perfectly united, victorious and in the highest spirits,according to Penn, when Benton returned to St. Iouls, in 1842. They looked forward to a harmonious and honorable career; to utilitarian changes demanded by the interests and security of the people. Nothing like discord was heard. The rank and file of the party were ani= (1) The Reporter was a daily paper and these letters appeared daily except the eighth and last whlch appeared November 7. (2) The letters Penn referred to were Benton's letter to the 

mated only by feelings of concord and patriotic enthusiasm, which promised to render the party invulnerable. Benton's arrival was anticipated by his friends with pleasure as they very naturally inferred that he would rejoice sincerely at the favorable change which had taken place. They talked of giving him a public dinner - of prevailing upon him once to depart from his established rule - (1) in order that he might publicly express the gratification, which they could not doubt that he felt, in consequence of the triumph of his political friends in the city of his abode.

Judge, then, what were their sensations, when they ascertained that he regarded the course they had pursued wholly erroneous and their success a misfortune. They had sinned in the policy pursued by the City Council, though it was forced on them, and they could not suddenly abandon it in consequence of contracts made by their Thig predecessors, without producing great loss to the city; they had neither displayed discretion nor wisdom in the election of members to the legislature; it was decided that most of the Bank Directors should be politically beheaded; in a word it seemed as if Benton had returned to Missouri, only to rebuke and make war upon a portion of his friends. It was at that time that the seed of Palmyra, Clay County, and Howard County committees. (1) It was an unalterable rule of Benton's never to accept a public dinner given in his honor. He, as other public men, of his time, often received invitations from various organizations to visit their city an attend a public dinner given in his honor. He always refused the public dinner although he might accept the invitation to visit the eity. This rule of Benton's was well known to his contemporaries. 

dissention was sown, that the course Benton pursued on local questions, and in reference to a portion of the Democracy,produced the jealousy and discord which had since ripened into an angry and unfortunate contest. The opinion at once began to be entertained by the most intelligent and energetic Democrats, that Benton could not tolerate a difference of opinion, even on petty local matters; moreover he at that time first took a stand against the Reporter and said it must be put down.'

Upon the political issues of the day, Penn attempted to show that he and Benton had always been in accord. He mentioned in particular his approval of Benton's report of 1826 in favor of a district system for choosing electors, his expunging resolution, his gold bill, his hostility to the assumption of the state debts, to distribution, to the Ashburton treaty, and his adherence to the strict construction of the constitution. Having shown that he and Benton had long agreed upon all political issues of importance, Penn declared his warm admiration for Benton's general course and the boldness with which he had pursued it. $Z$

Penn claimed to believe, Benton's mind had been poisoned, by the statements of a few malevolent men of small calibre, but he had expected Benton's good sense and sagacity to detect that his advisers were unsafe men, who "bent the suppliant knee that thrift might follow fawning", they were men who had lauded with indecent zeal, only because they supposed they 

could retain or ac uire office. Penn declared that he had labored several months to prevent those regarded as mere toadies from making Benton responsible for measures with which, as a servant of the state in the United States Senate he could properiy have nothing to do. These toadies had decoyed Benton into a false position; every move they made, according to them, originated with him and they did not hesitate to make him the author of all their charlatan views and projects during the previous session of the legislature. Col.Benton was everything - or interferring in everything- if they were to be believed; if a public paper opposed relief, repudiation or partial or profligate legialation it was warring against Benton. It was war upon Benton to object to caucus usurpation, to claim for the people the right to act for themselves in the selection of delegates to the National Convention, or to express a preference for any candidate for the presidency whom Benton did not approve. Indeed, Benton vas, in effect, represented by those who were in a habit of speaking as if authorized to speak for him, as one of the most medalesome, grasping, self-sufficient and arbitrary men in existence.

For the sake of the party to which both he and Benton belonged Penn said, that he had been unwilling to have such a reputation fastened upon a professed Democrat, and he had continued to combat, without reference to Benton, the positions of those who claimed to be his exclusive champions. 

Though they constantly held Benton up as their shield Penn declared that he chose to strike at the Clique and not at Benton, and even when in February, 1843, they had published in the Inquirer what purported to be an extract from one of of Benton's letters, (1) in which it was asserted that he (Penn) would come out against Benton as soon as he dared to do so he had not believed that Benton had ever uttered such charges. Penn then quoted from the Reporter of February 13, 1843, to prove that he had declared the charges false and had expressed his belief that Col. Benton was not the author. "His object," he said, "had been first, to show that he had desired no contest which might disturh the harmony of the party; and, second, to place the affair in such a light as to render it easy to determine whether Benton had misrepresented him, or the Inquirer had published a forgery, purporting to be an extract from one of Benton's letters. Penn maintained, that at that time he would not indulge the suspicion, that Benton was privately attacking him through letters, but that his friends had doubted whether Benton's disposition was amicable.

His friends, it was now ascertained, had understood Benton much better than he had; for while professing to admire no other than "an open foe and a manly contest" Benton had assailed him privately and had used the whole of the detested and

(1) The extract published in the Inquirer was as follows: "He (Penn) will come out against me the day he feels himself strong enough to do so. He had been watching for a good chance for a good while, and expected to find it in the debate on the British treaty." 

almost worn out Clique machinery against him and at the same time had affected to anticipate an attack from the Reparter, with a view to be prepared to cry out "persecution" so soon as he (Penn) might dare to enter out publicly upon his defense, Benton was so anxious for his destruction that he became too impatient to profit by his ingenuous artifice and openzy began an attack upon Penn without cause instead of acting on the defensive as he had planned. There could be no grounds for Benton's hostility to him unless Benton assumed the position that every one who differed on minor national topics or mere state questions, were necessarily his enemies; or unless he held that freedom of opinion was not to be tolerated, and that full fealty was due to him from the editors of Democratic papers of the state.

The fact that he had differed from Benton only on such issues as could be decided by the state of Missouri alone was emphasized by Penn, and he asserted that Benton had no right to determine what he or any other Democrat should say or do on state questions; that Benton might deny to the Democrats of the state of Missouri the right of private judgment, but that they would exercise that right in spite of him; that they were intelligent enough to guard and promote their own interests and would not submit to the dictation or arbitrary control of any man; that they had elected Benton to the Senate of the United States for twenty-four years and in that body they expected 

him to discharge his duty with fidelity to them and his country, but they neither desired him to manage state affairs nor expectod him to be familiar with such affairs, as he spent mas $t$ of his time in the East and had plenty to do if he did not neglect Missouri's interests or those of the nation in the halls of Congress.

For attempting to thrust upon the people his currency bills, Benton was then attacked by Penn. He declared, on the authority of Montgomery Blair, that Huston's bills were Benton's; on the authority of Judge Bowlin, that Redman's bills were Benton's; and on the authority of one of Benton's friends in the northern part of the state that Benton had prepared a similar bill in 1836. (1) It thus appeared that for four successive legislatures Benton had caused his "penal panaceas" to be presented to the legislature.

Benton had wholly lost sight of his position as a United States Senator, Penn declared. He had forgotten that according to the Jeffersonian creed, the "right of instruction" was in the legislature, and, as the servant of that body, he had no right to instruct its members, but was bound to obey. He was acting in contravention of the Democratic doctrine of instruction by urging, session after session, the enactment of unconstitutional, and odious laws, in opposition to the will of the majority of the Democratic party, and in doing so he was playIng the part of a disorganizer and a dictator. Penn suggested (1) For Huston and Redman's bill, see pp. 13-16. 

that he had better inquire whether the people and their legislators woula continue to endure such conduct.

Penn devoted his second letter to a detailed discussion of the currency question. "2 It was filled with personal thrusts at Benton. His third letter was given up to the districting question and a constitutional convention. "He began by saying that the sentiments of a prominent individual may generally be learned, by listening to the jabbering of those who cling to his skirts; Benton's views on the district question were very well understood as soon as the little Clique meetings in Callaway and two or three other counties were held. He then quoted Benton's statement in reply to the osage Yeoman (quoted in a previous chapter) and commented at considerable length on Benton's change of front since his report of 1826 .

Benton had been too long identified with centralism, Penn asserted and had derived too many personal advantages from it to abandon it voluntarily. The control he had exerted over a cabal, enabling him through its agency, to carry out his designs; the power which the combination had given him, inspiring awe in the breasts of timid and mercenary politicians would never be surrendered. Benton had become an admirer of Centralism and the General Ticket System, because the "discipline and management" brought into service under them had constituted in his hands" an unseen and irresponsible power", which he had regarded as irresistable. Penn said that the people now understood 

Benton's position and knew that the power in question was calculated to prevent, rather than promote, a faithful discharge of his duties in the Senate; and predicted that the would wrest it from him, that the central cabal would be crushed, that it would be allowed to exist no longer to tempt Benton to violate the principles he professed, and that the clique machinery would soon cease to operate. 3

The question of a constitutional convention for reapportionment was next taken up, and treated in such a way as to excite all the Anti-British feeling possible and turn it against Benton. (1) In his fourth letter, Penn quoted from Benton's Palmyra letter, (2) and answered him by attempting to show that he had been the aggressor and had pushed the fighting from the beginning.

In his fifth and sixth letters he declared that Benton's plan had been to have Dr.Penn elected President of the Bank, Col.Marmaduke Governor of the state, and Governor Reynolds appointed Judge of the Supreme Court. But these plans were foiled when the legislature refused to make Dr.Penn President of the Bank. He then devoted the remainder of the two letters to a discussion of questions of national politics in which he attempted to show that Benton had borrowed his currency ideas from other great national leaders particularly from Calhoun, that it was_only when Benton followed safe leaders that his ac tion

TIT Peñn described the rôten barough of England and the resulting inequality of representation, and then compared the conditions in Missouri to the condition in England at the time of the American Revolution. (2) See above, p. 62 . 

cohld be approved. He then spoke approvingly of Benton's gold bill of 1834, but said that Calhoun had proposed the measure in a speech in the Senate eight days before Benton brought in his resolutions. Again Calhoun had proposed that after a lapse of six years no notes under twenty dollars should be allo;ed to circulate, and after eight days Benton had brought in a resolution proposing that no notes under twenty dollars be received after a given period. He said, however, that Benton had not been so fortunate when he had elected to follow Senator Rives and had proposed to tax the circulation of the state banks under the revenue clause of the c'onstitution. Here he quoted Benton's resolutions in full and then quoted Calhoun to prove them unconstitutional. He also accused Benton of causing the division in the Democratic party at Washington through his control of the Globe which he had used to abuse the Democratic Senators, especially Calhoun, who had voted for the Ashburton treaty.

Benton's wonted decision of character had deserted him,Penn intimated in conclusion. Should his clique advise him to back straight out of state politics and cease to play the dictator, he would prove discreet and tame enough to do so. They would long since have tendered such advice to him but for their selifish desire to use his power to enable them to monopolize the of lices of the state. This had been the secret of their past devotion to Benton and it was the cause of the fervor of their faith in him. If they had sung hozannas they were inspired by ambition and not by love, and as the prospect of aggrandizing themselvos by the use of Benton's name might diminigh, their songs of praise vould 

gradually die away. Penn advised Benton to look to those whom he had regarded as faithful to the cause in Morgan and Howard counties and closed his characterization of Benton's Clique friends as follows: "Finally, when rode down by the charlatans in whom you confide, they will be the first to forget the good that you have done, and the most active and malevolent in exposing and condemning your errors and transgressions. Iike your special friend of the Globe they regard all minorities as anti-democratic, and whenever you cease to command a majority of the state, their peculiar principles will impel them, right or wrong, to denounce you as a recreant and a traitor. Mark this prediction. It may be verified sooner than you expect."

The publicaton of Penn's letters gave a renewed impetus to the factional fight and turned the emphasis from the currency and other issues to the personality of Benton. The two factions still called each other Hards and Softs but in reality they became Benton and Anti-Benton factions.

There are four principal lines of evidence which throw some light on the factional struggle during the winter of 1843-44. First, the press of the state, especially the Democratic press, was full of editorials on the subject. These were partisan in varying degrees, but usually quite bitter. The Whig press, although it professed to stand aloof, was certainly characterized by a strong Anti-Benton tinge. 2 Second, since 1840 there had 

been a gradual and fairly rapid growth of political organization. But this was accompanied by considerable opposition, sometimes violent, from those, known as Independents, who did not believe in political machinery and organization. This growth of political machinery took place in both parties but was much more rapid and popular in the Democratic than in the Whig party. Third, the proceedings and resolutions of the various county conventions in which the factional contest was fought give some valuable information. 3 Finally, the proceedings of the state convention held in Jefferson City on the first Monday in April, 1844, give some light on the final struggle between the factions for the control of the Democratic organization and the title of party regularity.

In February, 1844, there were twenty four political papers published in the state. (I) Fourteen of these were Democratic, and of the fourteen five were certainly Anti-Benton. They were the Missouri Reporter of St. Irouis, the Missouri Register of Boonville, the Iiberty Banner of Iiberty, the Grand River Chronicle of Chillicothe, and the Osage Yeoman of Narsaw. Five were undoubtedly Benton papers. They were the Missourian of St. Iouis, the Jeffersonian Republican and Jefferson Inquirer of Jeffers on City, the Missouri Democrat of Fayette, and the Platte Eagle of Platte City; although the latter was for districting it was a strong Benton paper. The Glasgow Pilot and (1) Statesman, Feb. 2, 1844. 

the Missouri Courier of Palmyra were for districting and were "Soft".(I) They were probably Anti-Benton but no definite evidence has been found concerning their position on Benton. There was also the Western Expositor at Independence, and a Democratic paper at Jackson the name of which is unknown. (2) The only indication as to the factional affiliation of these two latter papers may be found in the general sentiment of the communities in which they were published; this was Anti-Benton at Jackson, and probably about equally divided at Independence. The Ozark Eagle which had been rabid Anti-Benton had failed, and there was at this time no Democratic paper in Springfield. (3) Later the Springfield Advertiser was started and was a Benton paper, although it claimed to be Iiberal. (4) Much attention was given to the press by the leaders of both factions. Strenuous efforts were made by each side to support its own press and if opportunity offered to overthrow the opposition papers. The Missouri Register, possibly the strongest Anti-Benton paper in the state (the Missouri Reporter excepted), was compelled to suspend publication from January 16, to Apil 9,1844. The State Democratic Convention met April 1st. The suspension of a strong paper like the Register, located in the stronghold of the enemy might have very easily been a determin-, ing factor in the control of the Convention. The statesman, a Whig paper published at Columbia, said, "The Bentonian Locofocos, having failed to dhoke_off the editor of_the Register, have at -

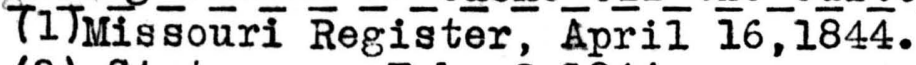

(2) Statesman, Feb. 2, 1844 .

(3) Statesman, February 2, 1844 .

(4) Ibid. 

last done what they would term the polite thing. His press was taken from him a few days since and is now in the hands of the sheriff.(1)

With the publication of the Penn letters the Democratic press took a more definite position. The Benton papers had insisted for nearly a year before Penn's letters were published that the real issue was "Benton or no Benton". (2) The Jefferson Inquirer in January,1843, after describing what he terms the St. Iouis coalition said, "Another object of the coalition is the overthrow of our distinguished Senator Thos.H.Benton. They dare not say so openly but they war upon him in disguise." (3) The Platte Eagle came out in a strong editorial in September, 1843, as follows, "We must fight corruption with a disciplined army and with this we may be defeated. We are alarmists, but what we say here is true. The issue though perhaps not avowed by our enemies will be 'Benton or no Benton'.(4) After the Penn letters were published the soft press soon agreed that the real issue was "Benton or no Benton", and the Missouri Register proposed that a column be opened on the pole books "Benton and no Benton". (5)

Neither side seemed to understand the real value of the mashinery of the party organization that had been built up. In I
(1) Missouri Reguster, June 4,1844.
(2) Jefferson Inquirer, Sept. 21, 1843.
(3) Ibid. Jan. 5, 1843.
(4) Platte Eagle, quoted in the Incuirer of Sept. 21, 1843.
(5) Missouri Register, May 7,1844. 

1840 there were no permanent committees. Campaigns had to be started by the newspapers. Usually one paper suggested a meeting or convention. If the suggestion met with the approval of the other editors in the territory concerned they copied and recommended the meeting. The press then got behind the convention and pushed it, and urged county or township meetings to elect delegate, etc. This condition probably accounts for the great importance attached to the press by all the politicians of the period. Committees of correspondence were appointed once the newspapers got a movement started, but their duty ended with the election as did the state Central Committee, which was simply a committee appointed from a few counties in the central part of the state, usually Howard, Cooper, Boone, Cole and Callaway. (1)

In, 1841, a series of articles appeared in the Jefferson Inquirer proposing and advocating a scheme for the permanent organization of the Democratic party. The writer proposed to hold county conventions annually at the spring court. It was suggested that at the first in the spring of,1842, a resolution be passed requesting the townships to hold meetings for the election of delegates to a county convention. It was pointed out that this would be necessary but once as the duty of convoking the township meetings would devolve in the future upon permanent standing committees which the plan provided. According to this plan (1) Miss ouri Register, october $2 \overline{2}, 184 \overline{0}$. 

the duties and powers of the county conventions were,- to nominate candidates, to appoint conferees for the Senatorial district, to appoint a standing committee, and to choose a committee on address. It was the duty of the standing committee to designate the time and place of holding township meetings to elect delegates to a county convention, and to appoint the time and place of holding the county convention. 5

This scheme for organization was discussed by its author in a series of articles which appeared weekly for about three months. (I) Objections to the plan were answered and delegate conventions in general were advocated. Permanent organization was especially insisted upon. The author declared that like systems had been established in older states and had given regularity to Democratic action and permancy to party success. (2)

The proposed plan for organization seemed to be popular, at least with the politicians and editors. Cole•County took the lead and a county meeting was held in March,1842, appointed a standing committee of two men from each township who were to hold office for two years. (3) No very definite plan of action, however, seems to have been generally agreed upon at this time. In October, 1843, an organization was formed in St. Iouis known as "The Democratic Association for the City and County of st. Louis. (4) october 31,1842 , a Democratic meeting was held in

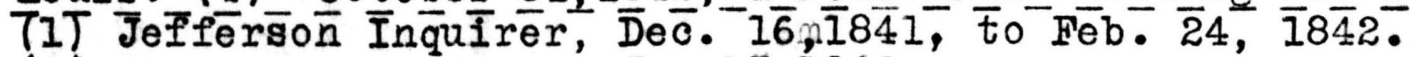

(2) Ibid.

(3) Ibid.

(4) Ibid. Jan.13, 1842. March 31, 1842. oct. 20,1842 . 

Jefferson City for the purpose of forming a Democratic Association. A committee was appointed to draft resolutions and the convention adjourned to meet November first. On the appointed day the committee reported brief resolutions recommending the organization if an association to be known as "The Democratic Association of Cole County" that the last Monday in February be named as the date for effecting a county organization, and that the committee be enlarged and be empowered and requested to prepare a constitution for the proposed Association. The committee as enlarged consisted of ten members among whom were W. Iusk, editor of the Inquirer; T.I.Price, later Iieutenant Governor; C.W.Hough, Representative; S.M.Bay, later Attorney General; E.I.Edwards, Congressman and later Governor; and W.W.Reynolds, Governor. This committee, it will be noted had in its membership a number of the most noted political leaders of the state. The work of drafting a constitution was perfected and at the appointed time was duly adopted. The general plan adopted both in St. Iouis and Cole County provided for a general committee to serve one year, for auxiliary assaciations in each township which were to elect three members to the general committee, (I) and for a state association of which the various county associations were to become auxiliary associations. The president, vice-presidents, and secretaries were to be ex-officio members of the general committee. The county associations were to hold four meetings a year.

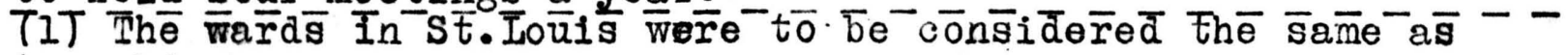
townships. 
Ue ? Maf showing the strmghode of tho Dimociatic factions in 1849-44. Data obtained

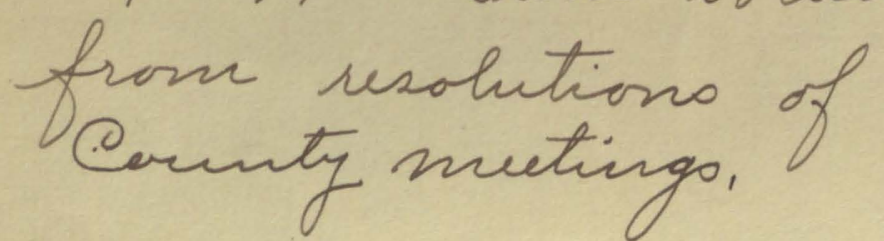
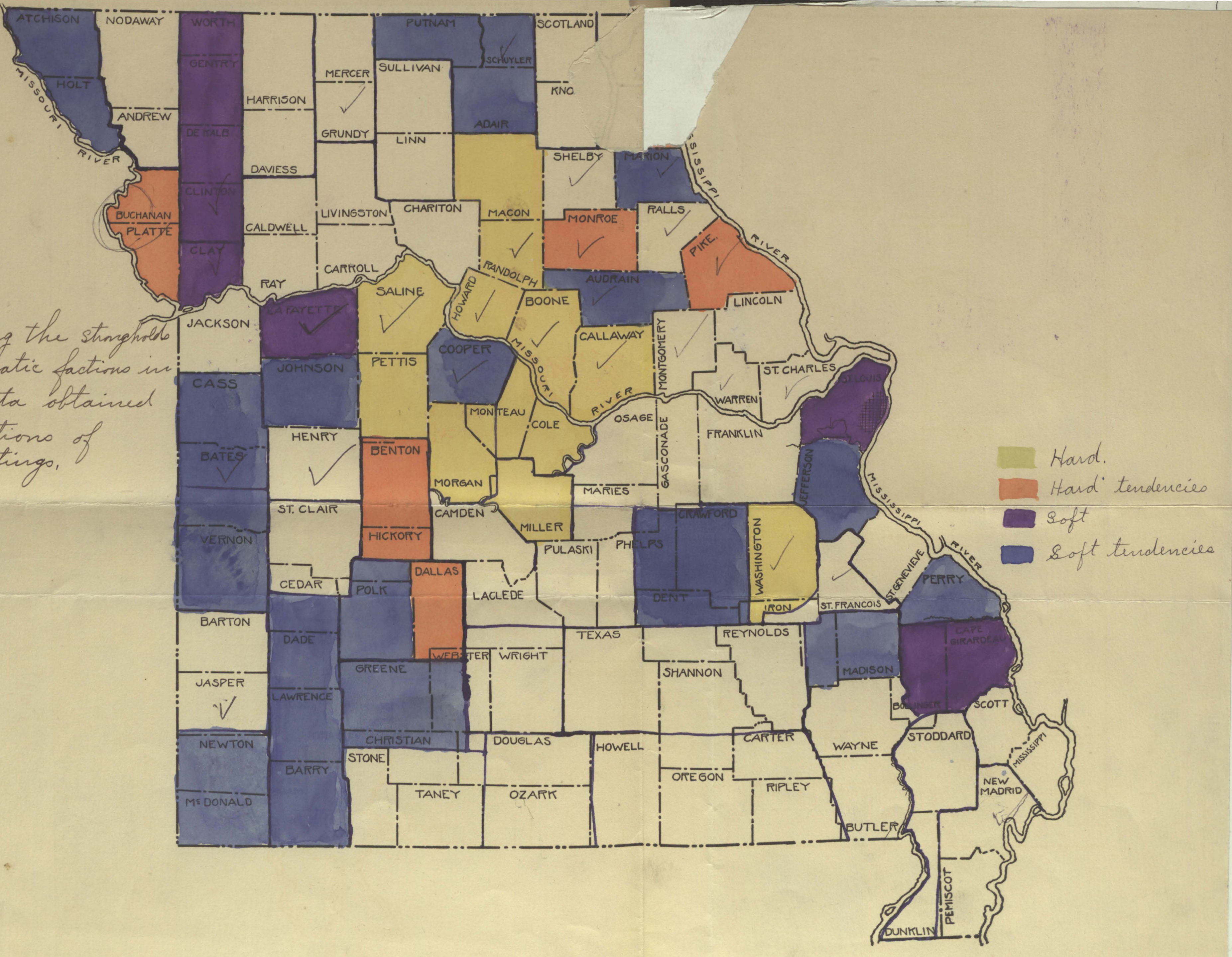

Organization seemed to be in the air. other counties followed the example of $\mathrm{St}$. Louis and Cole County and by the winter of 1843-44 a great many of the counties of the state had some kind of a permanent Democratic orgenization. These were by no means uniform, neither were they effected without violent opposition. There was no recognized central authority that had sufficient power to settle such questions as ratio, apportionment of delegates, order of procedure,etc. Often times territorial units were represented by an equal number of delegates without regard to their population, or voting strength. (1)

Just what candidates should be nominated by a $\infty$ unty convention was not determined. The politicians usually agreed that candidates for the legislature should be so nominated, but when it was proposed to nominate sheriffs and other minor county officials there were many objectors. Even the editor of the Jeffersonian Republidan was opposed to such nominations. (2) This uncertainty concerning the functions and purposes of these permanent county organizations, and even the desirability TIT For example a Whic convention was held in Bōne county in 1844, in which every township in the county was given ten delegates although Switzler and other leaders had attempted to have the representation fixed on the basis of one delegate for each fifty votes cast at the previous election. (Statesman Feb.9, 1844) Sometimes any number of delegates were allowed to sit from a territorial district with a certain number of votes given to the entire delegation to be cast as it desired. Thus the Democratic Convention of 1848 gave each county as many votes in the convention as the party in that county had cast for governor. in 1844 and the 'records of the convention show that the leading candidates received forty to fifty thousand votes each in the convention. (Jefferson Inquirer, April 1, 1848)

(2) Jefferson Republican, Mareh 26, 1842. 

of their existence probably accounts for the failure of the leaders to grasp their real significance. No one seemed to really understand their vast power. A great deal more attention was given by both the factions to the press than to the organization, and yet a spirited fight for the purpose of securing control of these organizations opened immediately after the publication of Penn's letters. Thus the party machinery had been developed and was in existence and ready for use. In the manipulation of this machinery the Central Clique had a very decided advantage over their opponents both in position and experience. It had been the custom for years at Democratic State Conventions to appoint a state central committee to serve during the campaign. This committee was always appointed from Howard, Cole, Cooper, Boone and possibly a few other counties in the contral part of the state. These men kept in touch with campaign committees correspondence in all the counties of the state. In that way they knew the political leaders in the various counties and were in turn known by them. The difficulty of communication made the scattered positions of the Anti-Benton strongholds, one in st. Iouis, one in the Northwest, and one in the Southwest, a great handicap.

As soon as "Benton or no Benton" had come to be acknowledged by all as the real issue the Hard papers began to refer to the constitutional convention, districting and even the details 

of the currency bills, meaning the penalties, as mere matters of policy upon which Democrats might honestly differ. The real question at issue was the election of the United States Senator. Missouri must stand by her distinguished statesman. To he disloyal to Benton, according to these papers, was to be a traitor to the party. This change of emphasis gave the Hards a great advantage. The Reporter, the leading soft paper, urged district conventions in Missouri for the purpose of nominating delegates to the National Convention. This was supposed to be against the interests of $\operatorname{Van} B$ uren. The Benton men who were usually Van Buren men were quick to accept the issue and favorod the nomination of delegates at the state convention according to the custom. The extra trouble and expense of holding these extra district conventions were their main arguments against them, while Penn argued that the Clique could much more easily control a state convention than it could five district conventions. The Benton men attempted to make the issue of a state or district convention a test issue. In all county conventions they urged a resolution in favor of a state convention, and usually got one passed. They then claimed all counties which passed such resolutions as Hard. The district convention idea never received any favor in Missouri and the fact that the Reporter urged the issue with so much insistence handicapped it in the contest. Penn even went to the extreme off_calling_a district_convention in_the_st.Iouis district.t. (1) (1) Jefferson Inquirer, Nov. 9,1843. 

but even there where the Soft movement was strongest no one attended and the project fell flat.

The convention was never a real test. To get the real sentiment it is necessary to examine the resolutions passed by the county meetings. There was a real contest in nearly all the counties of the state so that the resolutions passed meant something. The Central Clique probably had their lieutenants in most of these counties and probably half a dozen men attempted to call the meeting, get themselves elected as officers and committeemen, adopt a cut and dried set of resolutions, and have themselves sent as delegates to the state convention at Jefferson City, but the fight became too hot for that sort of thing to work well. (1) Both sides played at the same game and then it became a question of getting out the vote. Each man in most instances had an opportunity to vote for the kind of resolutions that he wanted on the questions at issue. While one side usually elected the chairman and controlled the committee on resolutions, the other side was always ready with substitute resolutions on the important questions. The real contest for the control and party name was fought out in these meetings.

Several of these county meetings are of interest. In S. Louis County it appears to have been certain that a meeting called in the city would have been Anti-Benton, therefore, a meeting was called at Manchester in October, 1843, before Coz.Benton started back to Vlashington. This meeting was under the auspices of the Hardas and Col. Benton attended and addressed it. ‥ The 

correspondent of the Missouri Register claimed that it was twenty miles from the city, and that there was only about twenty or thirty Hards from the city and about 150 country people present to hear Benton. (1) The Statesman said, "There were 185 people present by actual count and approximately onethird of them were Whigs". (2) Nevertheless, the few who were there went ahead and appointed ten delegates to the state convention to represent both the city and the county. Iater the st. Iouls Democracy got up a big meeting on the eighth of January celebration and appointed a contesting delegation. Many people had expected Benton to answer the Penn letters in this speech but he never referred to them either in this speech or in any other public address or letter. Concerning this mum policy of Benton's the Republican said, "He never has and will not now condescend to reply to any charge which may be brought against him, it matters not from what quarter it comes. When was a monarch known to reply to the assaults of a vassal? The policy is to kick the turbulent and dissatisfied out or whip them in." (3)

The contest in Benton County was carried to unreasonable extremes. In the meeting called to select delegates to the state convention there were two votes to one for R.M.Johnson of Kentucky, condidate for the presidency. It rejected a (I) Missouri Regtister, Nov6. $2 \overline{1}, \overline{184 \overline{3}}$.

(2) Statesman, Nov. 10, 1843.

(3) Republican, Nov. 21, 1843. 

a resolution praiging Benton and another pledging him support and still another pledging support to the state convention ticket to be nominated. The convention then elected eight delegates to the state convention. The Hards called another convention, got out forty men and elected a second delegation. At this second meeting a man named Cherry introduced a resolution calling on State Senator Major, who had been very active against Benton and the Hards, to resign. Cherry could not read or write and was unable to read his resolution when he had introduced it. Whipple the leading Benton man of the county was accused of writing the resolution. After the meeting Cherry, who seems to have been a more tool, of the Benton faction, attacked Major and cut him so severely that he died from the effects of the wound the next week. (I)

In Howard County the relative strength of the two factions as determined by the vote for Van Buren and Johnson was 156 to 75 respectively. (2) This convention denounced Penn bitterly in its resolutions, an example which was followed in four other counties. In Cooper County the vote on Van Buren and Johngon was 48 to 40 in favor of Van Buren, but the Benton men were glad to agree to a compromise by the terms of which Benton received a strong endorsement in the resolutions, while the Anti-Benton men dictated the resolutions on all of the issues (districting, constitutional convention and the currency bills)

(1) Statesman, March $15,1844$.

(2) Jefferson Inquirer, 'Dec.14, 1843. 

and received, at least, a part of the delegates.(I) The factions in many of the counties attempted some such compromise. In Ranajolph County the vote stood 49 for Van Buren and 48 for Johnson, but the Benton men controlled the convention selected delegates and adopted the resolutions - one condemning the Reporter. (2)

Forty sets of these county resolutions have been examined. Out of the forty only five were radically soft, while eleren were radically Hard; but seventeen shpwed soft tendenencies while only seven not radically Hard showed Hard tendencies. The counties which adopted soft resolutions were St.Louis, Cape Girardeau, Clinton, Clay and Iafayette. The Hard counties were Howard, Saline, Pettis, Cole, Morgan,Miller, Boone, Calaway, Randolph, Macon and Washington. The color map shows that there was good grounds for the charges of the existence of a Central Clique. All the radically Hard counties are groupad in the center in a compact group except Washington, and in this central territory all the counties were Hard except Cooper where the Missouri Register was published.

The color map also shows that there were three soft strongholds. One was in St. Iouis where the movement had begun. Another was in the Southeast the home of the late Senator Iinn, and of English a prominent Soft leader and later a candidate (1) Missouri Register, Jan. $\overline{9}, \overline{1844}$.

(2) These resolutions were found in the Jeffersonian Republicam the Jefferson Inquirer and the Missouri Regigter from Sept. 1843 to April 1844 . 

agrinst Benton for the United States Senate. The third was in the Northwest, the home of Senator Atchison and of A.A.King prominent soft, circuit judge and later governor of the state. There is no evidence that Iinn was Anti-Benton or that there was any disagreement between them, but according to an article in the Missourien the Reporter attempted to make the friends of Iinn believe that Benton had mistreated him. (1) The accusations were considered of sufficient importance to demand refutation by Benton's friends, one of whom wrote to Dr. Relf, Iinn's brother-in-law, to Governor Henry Dodge of Iowa, Ioinn's half brother, and to General Augustus C.Dodge of Wisconsin, Iinn's nephew, letters of inquiry as to the relations between Iinn and Benton. All three replied and the replies were all that Benton's friends could have wished. (2) The Missouri Register of May 28, 1844, in discussing the chances of the AntiBenton ticket in the Southeast said, "There is where the great strength of the honest and lamented Iinn commenced its rise, and the course of Benton and his Clique friends toward Senator Iinn is so well understood by the people, that the convention nominees (whe Benton ticket) are virtually abhorred in that community". (3) In considering the above statement the fact that the Register was a strong Anti-Benton paper must be remembered. Events proved, however, that there existed a strong Anti-Benton

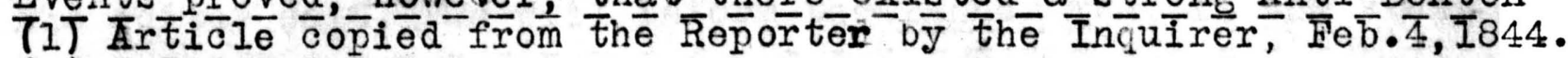
(2) Ietter of Smith and the two Dodges -Inquirer, Feb.4,1844. (3) Missouri Register, May 28, 1844. 

sentiment in the Southeast. Both the resolutions and the election returns are evidence of that fact. 3

In the Northwest the Anti-Clique feeling seemed to be stronger than in any other part of the state outside of st. Iouis. Three of the five counties from which radical soft resolutions were reported were in that section of the state. Two of the Soft papers, the Iiberty Banner and the Grand River Chronicle were located there. General Atchison, without doubt the most prominent man among the Softs, lived in Platte County. Atchison's later prominence makes it advisable to examine the evidence of his Soft tendencies. The exidence is largely indirect as there is no statement of his position made by himself at this time. There is enough indirect evidence, however, to settle beyond any reasonable doubt his position. Penn in an editorial asked the editor of the Inquirer if he would support any one of a number of men, including Atchison, for governor, the men named being Softs. (1) The Statesman gave an account of a meeting held in Clinton County a radical Anti-Benton county, which proposed Atchison for governor; Switzler, the editor, in his comments on this meeting said that this would prove embarrassing to the Central Clique. (2) In an editorial quoted from the Missourian on the districting question the editor said, We will inform the Banner that if the views

(1) Jefferson Inquirer, May 4, $184 \overline{3}$. 

of that paper accord with those of $i$ ts favorite Senator we have rea on to believe there will be no material difference between us in regard to districting. (I) The fact that Atchison vas the favorite Senator of the Banner, an open opponent of Benton, was significant as was also the evidence of his position on the districting question. A quotation from the New Era, a Whig paper published in St. Iouis, said that Atchison was a Johnson man; this also is significant though not conclusive; not all Johnson men were Anti-Benton, but most of them were. (2) The Inquirer said, General Atchison who has lately been appointed to a seat in the United State Senate prefers that the legislature should at its next session district the state." And again, "General Atchison believes Col.Johnson to be the most available man for president. (3) The Missouri Register, leading Anti-Benton paper outside of St. Iouis, said editorially, "Hon.David R. Atchison of Platte has been appointed to fill the vacancy caused by the death of Iinn. It is a good appointment. The Judge, unlike Col. Benton, is in favor of districting the state for the election of members to Congress,is a true and Iiberal Democrat, We have heard it intimated that he was recommended to the Governor by Col. Benton as a suitable man to be his colleague; if so, the Colonel is

degeived, for the Judge is a Johns on man, goes for the district
(I) Quoted in the Inquirer, January 4,1844.
(2) Jeffers on Inquirer, Nov.16,1843.
(3) Ibid.
Dec. 7,1843 . 

system and against the proscription of any portion of the Democratic party, which is more than we can say for Col.Benton. 61) Finally good evidence is found in the manner in which the appointment of Atchison was received in the Northwest. A correspondent writing in the Banner after describing the joy in that section over the appointment of Atchison sạid, "Governor Reynolds in this act has gone far to secure the gratitude of the whole Upper Missouri, he has acted justly, wisely, and well. He has done more by this act, to put down the rising indignation of the people, against the so-called Central Clique, - he has done more to prove that there is no such thing, or that it exists no longer, than a thousand semi-official bulletins of the Inquirer. We of the Upper Country hail this as an omen of peace and good will." (2) The state wide contest for th control of the party machinery closed in March, 1844, and the state convention assembled at Jefferson City the first Monday in April. It is impossible to get the details of the conflict there. They were purposely concealed. In the published report of the convention no resolution, motion or measure of any kind that failed to obtain a majority vote was mentioned. This action was in accordance with a resolution of instruction to the

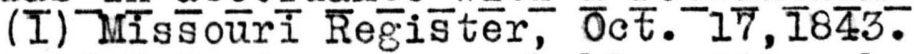

Col.Benton was probably not so badly deceived as the editor of the Register thought. He very likely expected just such a reaction as indicated by the passage quoted from the Banner, and he, no doubt, saw that if he were to be reelected it was necessary to prevent any opposition from Atchison during the campaign just then beginning and took that way of doing it.

(2) Iiberty Banner quoted in Jeffers on Inquirer, Nov.16,1843. 

secretary of the convention. No record of division on any resolution or other question, except the vote on the candidates for governor, involving the relative strength of the two factions has been found. All that is certain is that the Hards obtained control of the convention and tabled all resolutions relating to districting, consitutional convention, currency, etc and then forbad the secretary to publish the record of the vote by which these measures were tabled. 2

The Benton men succeeded in electing Sterling Price chairman of the convention. The Chairman appointed all committees, incluaing the committee on credentials, committee on resolutions and even the state central committee. The Anti-Benton delegation from Benton County withdrew from the convention upon the passage of the first resolution (quoted below) and the Anti-Benton delegation from St. Iouis was thrown out by the adoption of the report of the committee on credentials which seated the Manchester delegation. The first action of the convention after effecting a temporary organization was to pass a resolution "That all persons presenting claims for seats in this convention, hereby agree to submit their rights to seats to this convention, and pledge themselves to abide its action in reference thereto; and further, that all who have been or may be admitted to seats as members pledge themselves to abide by its selection of candidates, and to support its nominees in the ensuing election."(1) The fact that the above resolution (1) Missouri Register, April 16, 1844 . 

passed by a unanimous vote shows a wonderful growth in party loyalty, or at least in the desire to appear to be loyal to the party and to the convention system; and it may also be that it indicates doubt as to which faction would eventually control the convention and nominate the ticket.

During the pre-convention campaign there were three prominent candidates for governor. They were Col. Marmaduke, Iieutenant Governor and acting Governor, A.A.King, circuit judge of the Northwest circuit, and John C. Edwards of Cole County, former congressman. Marmaduke was an out and out Hard. He announced himself against districting, and for his opinions on the currency question referred people to his circular of 1840. He said that his opinions had not changed. This circular was a straight out hard money statement without any equivocation.(I) A.A.King was a soft, the favortte of the Northwest, a pronounced AntiCentral Clique section and had been mentioned along with Atchioon, Young, Campbell and others by the Reporter as being men whom the Inquirer would not support for governor. (2) Edwards oocupied a peculiar position between the extremes represented by the other two candidates. His position was well known. In the early part of the campaign he had been the favorite candidate of the Missouri Register, a prominent Soft paper. He had served in Congress from 1840 to 1842 and had been left off the ticket for (1) Jefferson Inquirer, Jan. $\overline{4}, \overline{8} 4 \overline{4}$. (2) Ibid. May 4, 1843. 

some reason by the state convention of 1842, although that year Missouri got five congressmen whereas she had only had two before. The Register claimed that he was defeated by the commands of the Central Clique. It was even charged that a sufficient number of votes cast for him had been counted for his opponent to change the result of the ballot. Edwards openly advocated districting the state, calling a constitutional convention and was opposed to the penalty features of the currency legislation. He was, however, from Cole County, had always been considered a close friend of Benton and the St.Iouis Republican, a Whig paper, said in 1842 that Benton had given his orders that Edwards was to be the next nominee of the Democratic party for governor. (1) Marmaduke's name was not presented to the convention. King received 42 votes and Edwards 66 votes and was declared the nominee of the party. (2) The convention selected Young, a man who had been identified with the Softs for lieutenant governor.

(1) St. Iouis Republican, Nov. 16,1842.

(2) If King's vote represented the Anti-Benton vote which it, most probably did the contest for the control of the convention and through it of the party machinery must have been very close. If the eighteen Anti-Benton delegates which represented St.Iouis and Benton County had been seated King would have been the nominee of the party by about the same majority which Edwar ds received. Probably no one denied that the soft delegation from St. Iouis really represented the sontiments of the Democratic party there, and the Whig and soft Press claimed that there was a two to one majority in Benton County for the Softs. These facts show how slim was the chance of Benton's re-election in the spring of 1844. 

The convention refused to take any position on the state questions and tabled all resolutions of whatever kind referring to districting, calling a constitutional convention, or the currency. So far as is sues were concerned its resolutions mentioned national questions only. The resolutions contained a brief endorsement of Atchison and the Congressional delegation, which Loughborough, a member of the convention from Clay County, said (in an article in the Iiberty Banner) was not in the original draft. (1) The principal resolution was the one endorsing Benton. It vas as follows: "Resolved, That the public course of Thomas H.Benton, as United States Senator from Missouri; his patriotic measures to increase the supply of constitutional currency - to establish the sub-treasury - to graduate the price of public land - to extend and make permanent the right of pre-emption - to abolish bounties on exports and duties on salt, and to provide for taking possession of Oregon - his stern opposition to the increase or extension of chartered monopoliesto the fraudulent bankrupt law - his war to the knife on the Bank of the United States,- his gallant defense and successful vinaication of Presidant Jackson from the recorded slanders of the Federal party, slanders which on his motion the people of the United States ordered to be expunged, intitle him to the unreserved respect, esteem, and confidence of the Democratic party (I) Missouri Registē, ApriI 30, I844. 

of Missouri." (1)There was also a clause in the Atchison Resolution "that we recommend to the Democracy of Missouri not to vote for any candidate for the legislature who will not pledge himself, if elected, to vote for the election of Thomas H.Benton and David R. Atchison as United States Senators from Missouri." The proceedings, resolutions and nominees of the convention make it clear that the fight was pre-eminently a "Benton no Benton" fight. The Benton men gave the Softs candidates, for governor and lieutenant governor, who had publicly advocated districting, a constitutional convention and had publicly expressed themselves against the penalties of the currency bill, and that too on a platform that dia not mention state issues; and only demanded in return party loyalty, close organization and strong support for Benton. But the Hards had secured possession of the party name, the title to party regularity; and in doing so had obtained an engine of political warfare whose power was to receive its first demonstration in Missouri in the ensuing campaigh. 

CHAP TER V.

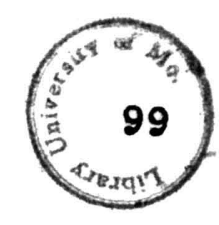

\section{CAMPAIGI AND EIECTION.}

The Democratic state convention adjourned April 4th and soon the delegates had carried the story of the convention to their home counties. The suppressing in the official proceedings of all resolutions and motions which did not carry seemed to make little difference so far as the spreading of the news of these things was concerned. (1) The Softs who called themselves "Liberal Democrats" immediately began publishing caustic criticisms of the convention proceedings. (2) The Missouri Register of April 9th devoted three columns of its editorial space to an account of the convention and promised more from week to week as the facts were learned, and it kept its promise. In this article it placed special emphasis upon the gag-law and the use of the previous question. The Iiberty Banner published a call purporting to come from the citizens of Clay County asking their delegates in

(1) The local press gave the stories of the convention as told by the delegates. The difficulty with these accounts is that they seldom give the text of the resolution, its author, or the vote by which it was tabled. The Missouri Register published some of the resolutions but simply made the statement that the convention had rejected them, without giving the vote. (2) The Benton faction had from the first rather liked the designation "Hards" but their opponents never seemed to have favored the name "Softg" which was derived from of the ordinary negative of the pord "hard" and did not signify anything as the word "hard" did when applied to money. From the first, therefore, the Anti-Benton men referred to themselves as "Iiberal Democrets" but in general usage the term "Softs" clung to them. 

the convention to give an account of the convention through the Banner.(1) The delegation responded with a three column article in which they gave some of the resolutions that had been rejected. In all these articles much emphasis was laid upon the state questions of a consitutional convention, districting, and the currency bills - usually referred to as bills of pains and penalties. (2) The Missouri Register published the so-called "bills" of pains and penalties", both the Redman bills of 1838 and 1840 an the Huston bills of 1842 in the issue of April 9, 1844. In commenting upon them it said, "It would be difficult to find a parallel for them in all the history of legislation. They breathe the true spirit of tyranny; and although they were presented to the legislature under the protense of doing good, no man, who understands what the spirit of a state should be can deny that these bills were better calculated to make knaves of our citizens than to improve the currency."

Thos. B. Hudson, of St. Louis, who announced himself as an independent candidate for Congress soon after the convention, defined his position in his letter to the pecple, as "favoring districting, and a constitutional convention, and uncompromising hostility to ty rannical enactments, like those proposed by Messrs (1) Missouri Register, April $16,1844$.

(2) By currency bills the softs a lwajs referred to those bills introduced by Redman and Huston, making it unlawful for the ordinary citizen to receive small notes; and not to the billa that had passed the previous legislature and was at that time a law of the state. 

Hust on and Jackson at the last legislature and commonly denominated 'the currency bills' ". He said, "That he had opposed the obnoxious currency bills, contending that their provisions violated the constitutional rights of the citizen, offered a bounty to swindling by enabling dishonest men to avail themselves of their own acts to escape from the performance of their contracts, degraded the citizen and warred upon his civil liberty, by requiring him to take odious test oaths, to swear prospectively that he would not exchange the products of his labor or merchandise except in a prescribed way, trampled upon the rights of the people and disregarded one of the plainest clauses of the constitution."(I) The convention was attacked for not taking a position upon these questions. It was alluded to as a "mum" convention, and much was made of its mum policy.

A second line of attack upon the convention was its arbitrary methods. The Register said, "We have reason to doubt whether the spirit of faction in any age or clime, either in the Jacobin intolerance of Revolutionary France, or in the inexorable fury of the Whig extra session of Congress, in 1841 , ever went farther to cut off all privileges of debate." A great deal was said about gag-law, the previous question, mot1ons to lay on the table, etc. - to quote; "A contemptible parliamentary jackscrew from Osage, was always in waiting to (I) Missouri Register, Aprii $30, \overline{1844}$ 

raise the previous question. He was the miserable catspaw of those tall and flerce spirits of faction who pulled the wires and directed the undercurrents, and who skulked into the background and poked out their heads occasionally to look after their jackscrew of the previous question."(I)

A third general line of criticism was directed against the convention's attitude toward Benton. The Anti-Benton press assailed the convention because it was willing to sacrifice everything for a man. It was accused of whitewashing Benton with its strong resolution of praise, and the resolution recommending that the Democrats vote for no man for the legislature who would not pledge himself to vote for Benton was especially condemned. General Ferry, delegate from Cooper County, said that in the convention, "one over ruling influence seemed to prevail which did not eminate from within but cast its shadow from afar; nor could anything relieve the dull, dreary and depressing sense of dependence under which the convention seemed to think and move."(2) Benton's oft quoted phrase, "All for the cause and nothing for men" was used with effect against those who had shown themselves ready to sacrifice everything for Benton.

While there seems to have been a great deal of dissatisfaction among the Democrats concerning the convention action, yet there was no organized effort to hold a convention of the Anti-Benton men. Probably the failure to make any effort to (I) Missouri Register, April $9 \overline{-}, \overline{1844}$. (2) Ibid. Apri 130, 1844. 

hold a convention was due to the fact that the convention as a method of placing candidates before the people was comparatively new and there were a great many who doubted the wisdom of using it at all.(I) Many people considered it similar to the much discredited caucus, and very likely the Democrats who were disgruntled would be appealed to more easily by a ticket presented through the personal iniative of the candidates than one put in the field by a hastily called convention.

Judge C.H.Allen, a strong Anti-Central Clique man, had announced himself as an independent candidate for governor, at least, three months before the convention met. (2) Candidates began to announce for the various offices in rapid succession as the news of the convention action spread over the state. So many announced that it becrme necessary to

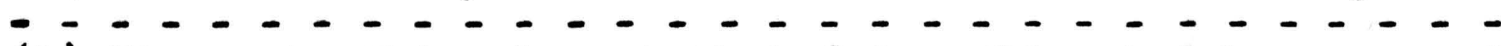
(I) It was to this element that Judge Allen had been appeal- . ing for three months before the state convention met. He denounced conventions and certainly would not have been bound by the action of one. St. Louis Republican, Dec.23,1843. (2) St. Louis Republican, Dec. 23, 1843. Judge Allen was a Democrat of long standing and had been circuit judge for several years. He had quarreled with the leaders of this party and had become bitterly hostile to the central clique. He seems never to have believed in the organization of party machinery. In this he was not in accord with the Softs in general for they were as ready to organize as any one and saw no evil in conventions until after they were beaten in the fight for the control of the party organization. December 23, 1843, the St. Louis Republican in an editorial said that Hon. C. B.Allen, familiarly known as "Horse" Allen, independent candidate for governor had arrived in the city and would speak at the court house that night, then said. "We say nothing of the Horse's politics or present 

have an understanding among them to prevent more than one man from running for the same office. This was accomplished by correspondence and conferences among the leading Softs. Ex-Governor Boggs announced for Governor, but as Allen could not be pe rsuaded to quit the race, he withdrew from the gubernatorial contest and announced for Congress, but finally crowded out altogether, he withdrew from the ticket.(1) To arrange the ticket was a very difficult task. Sometimes the real leaders were compelled to withdraw in order to prevent a multiplicity of candidates. Thus Carty Wells, later president of the constitutional convention, who had announced political position, but he is an interesting and forcible stump speaker, has a tolerably logical mind, and a large fund of anecdote; powerful lungs, and does not care a farthing who approves or disapproves of his views. He is a good deal selfwilled and when he takes a course he is likely to keep on it. Opposition only begess stubbornness in him. Take him all in all he is a very clever man, but not just the kind of stuff we woula like to see made governor, but probably quite as good material in the raw state, as we are likely to get from a Locofoco nomination"

In his speech Allen maintained that he was as good a Democrat as Bent on was. He struck at the Central Clique with all his might; exposed the schemes of the clique, depicted their method of controlling the thing called a county meeting, securing the resolutions wanted, and appointing delegates to go to the convention at Jefferson City, where Allen declared, that "the highest offices of the state were parceled out and gambled for." He favored the district system, a constitutional convention; reform of the juaiciary; was against the currency bills and dian't believe there was an honest Democrat in the state who favored them.

(1) Jeffers on Inquirer, Apr. 25, 1844 Ibid Missouri Register

May 23,1844

May 14,1844 . 

for Congress from the Northeast had to with-draw for Ratcliff Boon.(1)

By the end of May the ticket has been arranged. The Missouri Register, the first paper to place the ticket at the head of its editorial column as the Liberal Democratic ticket, came out May 28, with the full ticket as follows: Governor, C.H.Allen; Iieutenant Governor, Wm. B. Almond; for Congress Leonard H. Simms, of Greene County; Thomas B. Hudson, of St. Louis; Ratcliffe Boon, of Pike County; John Thornt on, of Clay County; and Augustus Jones, of Washington County. The Missouri Register said, "We place at the head of our column this week the Independent Democratic ticket as it appears to have been settled upon by the Iiberal Democratic party of the staten Other candidates soon withdrew and the lines became definitely drawn between the two Democratic tickets.

The Thigs had early decided not to run a state or congressional ticket, but to concentrate their efforts upon the legislative ticket and attempt to carry the legislature and beat Benton. (2) The Whig press assumed the attituae of disinterested spectators and repeatedly urged their followers not to participate in the contest between the two Democratic tickets. Their usual sentiments are well expressed in the New Era. a Whig paper of St. Louis and quoted with approval in the

(1) Jeffers on Inquirer, April 18, 1844.

(2) Statesman, Sept. 1, 1843. 

Statesman, as follows: "This is a contest, however, in which the Whigs have nothing to concern them. It is nothing but a case of litigation between the aescendents of old Mr. Clique, by which to determine whether the law of primogeniture, which entalls his whole estate on his eldest son - caucus born - shall prevail,or whether the will of Democracy shall be established which devides the estate among all the children share and share alike."(1) But in spite of this attitude of the Thig press the Whigs in general undoubtedly sympathized with the Independents and more and more as the campaign progressed allowed that feeling to manifest itself. This sympathy eventually developed into considerable activity in behalf of the Independent candidates.

While the Independents vehemently denled any connection with the Whigs (2) it soon became apparent that they would get a large Whig vote and $t$ is fact was a very important factor in lining up the Democracy of the state for the regular ticket.(3) The regular Democrats left no stone unturned to prove the connection between the Whigs and Independents. The clay club of st. Iouis sent out a confidential letter to Whigs sometime in March before the Democratic convention met. This letter asked a number of questions and gave some instructions for Whigs to follow in the campaign. The Inquirer got hold of the letter and published it in the issue of April 4th. After that it

(1) Statesman, April 5, 1844

(2) Gen. Ferry, prominent soft of Cooper County, came near fighting a duel with Huston, of currency fame, because Huston called him a Whig. Correspondence published in Missouri Register May 14 , to June 6,1844 .

(3) Jefferson Inquirer, April 18; Way 30; and June 6, 1844. 

answered one question each week editorially. Two of these questions which show the real Whig plans deserve quoting. First: "Will the Independent Locofoco candidate for governor, Horse Allen, succeed in obtaining any support, worthy of notice, from the Locofoco party in your county, in the event of a 'Hard' being nominated by the Iocofocos for governor? If so, how many votes do you think there is good reason to believe he can get among them". (1) Second; "Will there be a Whig ticket for the legislature in your county this year? If so, with what prospects of being elected? If not, what is proposed to be done with the Whig vote in August? Is there, or can there be created such a division or multiplication of candidates among the Locofocos, as would enable the Whigs by their votes to elect an Anti-Bent on man?"(2) These questions were the basis of articles upon "Plans of the Whigs-Independents", etc.

The regular Democrats emphatically denied the assertion of the Whig and soft press, that the convention was against a constitutional convention, against the àistrict system, and in favor of the currency bills. They declared that the convention had not gone on record for or against these questions, but had simply refused to consider them as vital issues or tests of Democratic principles, that the candidates had been selected without regard to these questions; but, as a matter of fact, both Mr. Edwards and Mr. Young, candidates for governor and lieutenand governor, were in favor of a constitutional convention and Jefferson Inquirer, Aprii $\overline{11}, \overline{1844}$. (2) Ibid. April 25, 1844. 

districting, and against the details of the currency bills (meaning the penalties and test oaths).(1)

This position practicaliy took away from the Independents their issues, and confined them to opposition to Benton, the only issue upon which the Regulars would disagree with them. The chief arguments of the Regulars were those of party loyalty. Treachery, trait or candidates, traitor papers, and traitor party were common expressions.

These professions and charges were met by the Independents with charges of egotism, dictation, and tyranny against Benton; (2) with editorials upon "pains and penalties, test oaths, and proscription"; with charges of insincerity and hypocricy against the Hards in their attitude on districting, a constitutional convention and the currency bills. Thos. B. Hudson, in the letter announcing his candidacy for Congress, said, "It matters not what hypocritical professions may be made in the present contest, the position of the convention cannot be denied. That position has been made known by repeated votes of the convention in opposition to the District Systen, and constitutional reform, and in favor of Bills of Pains and Penalties".(3) The Missouri Register speaking of the Hards said, "The now strive to show themselves friendly to all the measures which the Iiberals advocate. They do this because they see that the liberal - - - - - - - - - - - - - - - - - . - (1) Jefferson Inquirer, April 11, 1844.

(2) Missouri Register, June 11, and 25, 1844.

(3) Wis s ouri Register, April 30, 1844. 

measures are bound to succeod, notwithstanding the order given by Tom Bent on, at the outset, that reform must be choked dow $n . "(1)$

Party organization was used effectively and some great changes began to take place. In the sixth ward in St. Louls, a meeting was called by the Penn faction to send delegates to a county convention. One Harold, who had long been with Penn, nominated a chairman and secretary, also long active Penn men, and then made an address in which he denounced Penn and the whole independent movement, declared himself undeceived and from that time on a reguiar Hard - A Bent on Democrat. He then introduced a set of resolutions declaring al legiance to the nominees of the Democratic state convention, condemning the discention and in particular denouncing Thos. B. Hudson, Independent candidate for Congress, and declaring there was no need of a meeting to appoint delegates to a county meeting.(2) The Resolution was carried with but one dissenting vote. The Grand River Chronicle published at Chilicothe had all alone been with Penn, but after the convention it came out for the regular nominees, and said that the Independents would get little encouragement in that section.(3)

Many letters and extracts from letters were published by the Inquirer telling haw the Democrats were lining up for the (1) Missouri Register.

(3) Jefferson Inquirer, May 2, 1844. 

ticket, etc. The following extracts are typical. One from Holt County declared, "the Platte country will go solid for Edwards". (1) From Neosho, that the nomination of Edwards had given universal satisfaction and that there was but one vote certain for the "Horse" in Newton County:(2) From Springfield, "You mey depend upon this county for an immense majority for Edwards"(3); From Greenfield, "I have been through several counties in this part of the state in the last four weeks and I assure you the Democrats are wide awake. The support the Whige are giving the Independent ticket has opened the eyes of the Democrats. They have no notion of joining the Independents and breaking down the Democratic party, merely to give some half a dozen hungry offico-seekers a pull at the treasury." (4)

The Anti-Benton men claimed that Benton, secretly, was not loyal to the national Democratic ticket for which they professed great enthusiasm. Benton's strong preferences for Van Buren were well known in Missouri. Soon after Polk's nomination Benton wrote a letter to the Missourian, intending it to be published for the benefit of Polk and Dallas, in which he said, "Neither Mr. Polk nor Mr. Dallas, have had anything to do with the intrigue which has nullified the choice of the people.... and neither of them should be injured or
(1) Jefferson Inquirer,
(2) Jefferson Inquirer.
(3) Ibid.
(4) Ibia.
May 30,1844 .
May 30, 1844.
June 6,1844 . 

prejudiced by 1t.........The people now as twenty years ago will teach the Congress intriguers to attend to law-making and let president making and unmaking alone in the future. The Texas treaty which consumated the ir intrigue was nothing but the final act in a long conspiracy in which the sacrifice of Mr. Van Buren had been previously agreed upon."

The Softs attacked Benton's letter dwelling especially upon the words "intrigue" and "Congress-Intrigue". In an oditorial in the Missouri Register. Benton was made to say that Polk and Dallas were nominated by Congress intriguers. The editor then said, "If they are the tools of intriguers nelther Bent on nor anybody else can conscientiously support them. The receiver of stolen goods is as bad as the thief.(I) He then declared that the statements concerning intrigue in Bent on's letters were false, that the statement that the Texas treaty was brought about to defeat Van Buren was false, and that Bent on was determined to ruin the national Democratic party as he had already ruined the party in the state.

But the chief attacks upon Benton in the later part of the camprign and the ones which seemed to have the greatest effect were those directed against his attitude on the annexation of Texas. Benton had that Western spirit of expansion which caused him to resent the loss of a single foot of territory and made him always ready to see any territory acquired that (1) Missouri Register, Juné $\overline{25}, \overline{1} \overline{1} \overline{4} \overline{4}^{-}$ 

could be obiained with honor. He had opposed the treaty of 1819 in a series of articles signed bmericanus and published in the St. Louis Inquirer, because it gave Texas to Spain. In another series punlished in the st. Iouis Beacon in 1829, signed La Salle, he advocated the acquisition of Texas and he always favored the annexation of Texas at anytime that it could be brought about without compromising the honor of his country.

In 1844 the Tyler administrion negotiated a treaty with the Republic of Texas which provided for its annexation to the United States.(I) The prospect of getting Texas was halled with delight in Missour1, but to the surprise of every one, friends and enemies alike, Benton came cut against the ratification of the treaty. Why he took such a position immediately became a matter of controversy. His enemies claimed that he was actuated by contemptible motives of jealousy of Calhoun, and that his arguments against the treaty were without a basis of fact(2) His friends said that opposition to the trety was not an evidence of faithlessness to democracy, or a break with his party and commended the courage and mhood which he showed in the contest. (3) Benton certainly displayed courage in taking the position that he did against annexation at that time. Every one knew that annexation was excoedingly popular in Missouri, and no - - - - - - - - - - - - - - - - - - - (1) Congressional Globe, Vol, 13, 1843-44. Pages 568,607 \& 611

(2) M1s\& ouri Register, May 21, 1844.

(3) Jefferson Inquirer, Nov. 14, 1844. 

one knew it better than did Benton. He knew also that he had a tremendous conflict on his hands in Missouri in which his very political existence was at stake.

Benton said that the treaty was "a scheme, in the part of some of its movers, to dissolve the union - on the part of some others, an intrigue for the presidency - and on the pert of others a land speculation and a job in script."(I) He declared that to ratify the treaty meant war with Mexico. He was very much averse to war with Mexico and was especially anxious to cultivate friendly trade relations. Probably his jealousy of and opposition to Calhoun tended to cause him to oppose the treaty; certainly, his knowledge of Spanish land grants and the claims based upon them enabled him to see the defects of the treatio in this respect; and his ardent devotion to the union caused him to oppose what he though was a scheme to dissolve it; but no doubt his chief reason for opposing the treaty was that it would bring on a war with Mexico. In tinis last objection, at least, later events proved that his judgement was correct.(2) The treaty, largely through Benton's efforts, failod of ratifi cation in the Senate of the United States. He then intro-

(1) Jefferson Inquirer, July 4th, 1844. (2) Ibid. 

duced a bill providing for the annexation of Texas by a method which he said would avoid war with Mexico.(I)

But why should Benton be so averse to war with Mexico? He did not ordinarily avoid a fight. No true westerner did, and probably the one ambition of his life was to become a military hero.(2) His peculiar aversion to war with Mexico at this time can only be understood when we view the situation from the viewpoint of Benton's fundamental public policy. There can be no doubt but that Benton's dominant interest in public questions was centered around the currency problems. Soon after the failure of the territorial Bank of Missouri, of which he hod been a director(3), Benton had iaken a strong position in favor of gold and silver as the constitutional curreney of the country; he bad been the real moving spirit behind Jackson in the beginning as well as throughout the fight against the Second Bank of the United States.(4) (1) Congressional Giobe, Vol. 13 , Session $1843-44$. Page 474 . (2) Bent on had joined the army in 1812, and became Colonel. When he quarreled with Jacks on he resigned because he saw that he had no chance for a military career with Jacks on against him. After his el ection to the United States Senate he took a deep interest in the army, and was for many years chairman of the committeo on military affairs. Twice during Jackson's administration he was slated for the chief command of the army in case of war which semed almost certain, once wi th France and at another time with Mexico(Meigs, Life of Benton, pages 363-367). When Polk was looking for a general for the Mexican war, Benton laid a plan of campaign before him and proposed that he himself woula accept tho chief command of the aray and carry it out. Polk attempted to have him made Lieutenant-general but was folled by Benton's enemies in the Senate. A military career is the only thing that ever tempted him to resign from the senate. He always refused cabinet positions or diplomatic appointinents (and such positions were offered him weveral times) but he seems to have been wilt ing to resign for a military career at least three times. (3) Statesman, Jan. 19, 1844. (4) Thirty Yrs. View,V.I,pp 158. ff 

He had secured the change in the ratio between gold and silver that had caused gold to circulate.(1) He had suggested and always worked diligently for the subtreasury. (2) He had proposed that the United States tax the currency of the state banks out of existence.(5) In a speech in 1840 , which was reprinted in the Inquirer in 1843, just after Benton had visited Jefferson City. Benton said, "The currency question is the greatest question of the age", and later in the sarne speech, "I repeat it, the currency question is the great question of the age; it absorbe and swallows up every other." And it was his attempt to put into practice his currency ideas in the state of Missouri that had involved him in a fight to the bitter end for his political existence. Benton's position on the Texas treaty and his aversion to the war which he believed would follow its ratification becomes clear when it is viewed from the stanapoint of its effect upon the currency situation in the United States and especially in the West.

The great obstacle to Benton' s curreney schemes was the lack of sufficient hard money for circulation. He had always claimed that the hard money would come if the small notes were not allowed to circulate.(4) Hence, his effort to have the legislature of Missouri prohibit under heavy penalties the circulation of sall notes in Missouri. But if small notes were (1) Laughlin's Principles of Money. pp $4 \overline{2 \eta}$ ff. (2) Thirty Years' View, Vol. I, pp 158. (3) Congressional Globe, Vol. 10-1841-42 - 27th Congress, 81 ff. (4)Benton's Speech, Jefferson Inquirer, Aug. 31, 1843. 

not to circulate, gold and silver must be obtained to circulate in the place of them. Where was it to come from? Benton looked to Mexico for much of it.

In a speech in the senate on his bill for the adnission of Texas he urged as the chief claim for the superiority of his bill over the treaty, that it would avoid the war with Mexico, which the treaty would have caused. After showing that such a war would be unjust and dishonorable he said, "Policy and interest if not justice and honor should make us refrain from this war. We have, or rather had, a great commerce with Mexico, which deserves protection instead of destruction. Our trade with this country commenced with the first year of her independence - 1821 - and we received from her that year $\$ 80,000$ in specie. It increased annually and vastly and in the year, 1835, the year before the revolution, this import amounted to $\$ 8,343,181$ on the custom house books, besides the amounts not entered.(1) our sympathy and supposed aid to the Texins lost us the favor of the Mexicans, and the import ran down in seven years to $\$ 1,342,817$. New Orleans, and through her, the great West, was the greatest gainer by this import of specie while it flourished - of course, the greatest loser when it declined; and instead of destroying the remainder of $1 t$, and all commerce with our nearest neighbor, by an unjust assumption of a war against her, we should rather choose to restore this specie import to its former 

maximum and increase it. We should rather choose to cherish and improve a valuable trade with a neighbor that has mines, and whose staple product is silver, which is exchanged for our agricultural productions, after these productions have gone to Europe or the West Indies and been changed into fine goods or groceries. Atlantic politicians hot in the pursuit of Texas, may have no sympathy for this Mexican trade, but I have; and it has been my policy to reconcile these two objects - acquisition of Texas and the preservation of the Mexican trade - and, therefore, to eschew unjust war with Mexico as not only wicked but foolish."

Benton in his letter to the Texan Congress dated May 2 , 1844, in which he urged the desirability of annexation without war, used the same arguments and stressed the importance of the import of gold and silver into the United States. In this letter he said, "For the last year(1843) this trade had somewhat survived, and rose to two million dollars; with proper care it y be carried higher, at all events we should be careful not to drive it away by a breach with Mexico. The whole import of gold and silver to all parts of the United States was about eleven million dollars at the commencement of the Texan Revolution. It has been diminished everywhere as at New Orleans; and the whole import of 1842 was only a fraction over a million and a quarter."(1)

(1) Benton's Letter to the Texan Congress - Inquirer, May30'44. 

But these as well as a 11 other arguments apoeared to fall upon deaf ears so far as Missouri Democrats were concerned. Even the Jefferson Inquirer, probably the strongest Bent on paper in the state, in the same issue in which it published Benton's letter to the Texan Congress had an editorial a column in length advocating the immediate annexation of Texas. The Missouri Register's columns were full of attacks on Benton because of his position on the Texas treaty, for three months before the election. He was accused of being a traitor to his country and to the West in particular, of being in alliance with the British, and of going over to the Whigs. The letters of Clay, VanBuren, and Benton, all opposing immediate annexation, were compared and attacked bitterly, especially that of Benton. A fair sample of these attacks is found in the Missouri Register of May 14, 1844, After commending the administration very highly and condemning the politicians who opposed the Texas treaty the editor speaks of Benton thus, "Mr. Benton is also opposed to the annexation, but this is no more than one might expect of a man who has the meanness to oppose Liberal principles in a state which has made him what he is. He is a demagogue and a tyrant at heart, and has succeded too long in hiding his real character from an honest and confiding people. He is the greatest egotist in Christendom. His Texas le tter abounds wi th it to disgust, and his arguments about the commerce of 

Mexico is mere diplomatic bombast to divert attention from the real state of the case and hide the actual worth of Texas to our union to the mind of every man who puts faith in his deceptive assertions".(1) Jackson's Texas le tter is then quoted against Benton. Another editorial, a column in length, appeared in the next issue under the heading "Texas now or Never"; in this the editor said, "What a strange and unnatural coalition Messrs Van Buren, Clay and Benton have so suddenly formed to oppose the annexation of Texas, etc. . . It now devolves upon the unterrified Democracy of the nation, with the veteran heros Jackson, Johns on and Cass; the sage politicians and statesmen Calhoun, Walker, Polk and Ritchie with the present administrations to take up the question and carry it through. . . . . It is obvious van Buren stands in awe of the infernal abolitionists of the North, and Benton is merely actuated by contemptible jealousy of Calhoun. They must not be permitted to stand in the way of the onward and upward mareh of our country to those high and holy destinies to which God and nature seem to have designed. May a dishonorable grave and a name forever infamous be the fate of him who will thus sacrifice the highest hopes and the dearest interest of our native land ." (2) (1) Mis souri Register, May $14,-\overline{1844}$. 

Public meetings were held in many places, and resolutions were passed demending immediate annexation. C.F. Jackson and Judge Rawlins of Howard County, candidates, one for the House and the other for the State Senate, and both old political friends and supporters of Benton and leaders in the Fayette Clique, declared publicly in their campaign that they "would not vote for Benton or any other man for the United States Senate who was opposed to the immediate annexation of Texas".(1) The Whigs approved of Benton's course on the Texas treaty, but this Whig endorsement only served as a further handicap to Benton in the eyes of all good Dernocrats(2).

In the face of all this opposition Benton did not flinch or waver on his position. He came to Miscouri as soon as Congress adjourned and made a speaking tour in which he spoke at St. Louis, Jefferson City, Boonville, and other points and always explained the Texas question and why he opposed the treaty.

The speech at Boonvilie delivered at a great Democratic campaign rally Julg 17, 1844, is typical of his campaign speeches during this summer. He first declared his personal disinterestedness in the election, he said that it was norebecoming of him to thank the people of Missouri for having elected him four times to the Senate of the United States (1) Missouri Register, June il, 1844 . (2) Ibia. June 4, 1844. 

than to ask for a fifth election, that he was not a candidate but that he left his interests in the hands of his friends, the Hards. He then proceeded to discuss the Texas question. He called on all present who had lived in Missouri in 1819 to witness that he had been the first to write and speak against giving Texas away and the first to suggest annexation. He said he had been asked many times since his return to Missouri whether he favored the annexation of Texas. This questior sounded in his ears about like a question would have sounded in the ears of Thomas Jefferson inquiring of him twenty-five years after he had written it and supported it, whether he favored the Declaration of Independence. Not only had he drawn the first pen against the treaty, he had written and spoken in favor of annexation more than any one else in the world, and he had introduced $a \mathrm{bill}$ in the senate for annexation in the only possible way. He thenproceeded in great detail to give an account of the making of the tresty of 1819, and fastened upon Calhoun the responsibility for giving Texas away. He next made an extensive argument against the treaty for annexation negotiated by Calhoun, denounced it as "carefully and artfully contrived to dissolve the union". He followed this with an elaborate argument in favor of his bill and the importance of getting Texas with out offense or war with Mexaco, which he said would be accomplished by his measure. 

Atchison had voted for the treaty and he was compared to Benton and held up as a truly model American statesman and patriot by the Anti-Benton papers. The Miscouri Resister contained the following article, the headines in large type:

"HUZZA FOR ATCHISON, TEXAS, AND AMERICA" "A letter has just been received in this city from that able, fearless, and indefatigable champion of Western interests, Hon. Davia R. Atchison. We give the following brief extract for the benefit of our Van Buren, Benton, Clay, anti-American, and anti-Texas friends". It then quotes Atchison as saying that he is going to vote for the treaty because he thought it was all important to the best interests of the whole valley of the Miselssippi river and particularly to the state of Mis souri. The editor then comments, "There is a true patriot for you. He has an American heart in his bosom, and it is as near the right place as any man's. The successor of the lamented linn is worthy of the distinguished station and honors that have been conferred upon him. He is far above the petty partisan jealousies of the day, and long will the noble stand he has taken in defense of the endangered rights of his country remain an honorable monument in his history".(1)

(1) M1 ssou r1 Register, May 21, 1844. 

Benton's stand on the Texas treaty must have lost him a good deal of support. It gave those politicians whowere getting tired of his leadership, or who were secretly opposed to him a chance to come out in opposition to him on a popular question. Probably Jackson represented one of these types and Atchison the other. Jackson openly came out against Bent on on annexation and declared that he would not vote for him if elected to the legislature, but there 1s no evidence that Atchison opposed the re-election of Benton in Missouri. He seems to have stood aloof from the fight after his appointment to the United States Senate, but he bold ly took a position against Benton on the treaty when it was being considered in the senate.

At this time the election for state officers and congressmen was held early in August. At this election the regular Democratic candidate for governor, Edwards, was elected by a majority of 5621 over the Independent candidate, Allen. When this majority is compared with those of other elections just preceding and following, the narrow margin by which the regular Democrats won their victory becomes more noticeable. In the election of 1840 although there was a general Whig landslide all over the country, Governor Reynolds was elected by a majority of 7867 . (1) In the November election just (I) Jefferson Inquírer, sept. $\overline{17}, \overline{1840 .}$ 

three months after Edward's election Polk carried the state by 10118 majority; (1) and in $1848 \mathrm{King}$, the Democratic nominee, was elected governor over Rollins, the Whig candidate, by a majority of at least 15264.(2).

The Whigs at the previous election had secured 26 members in the House. This number was increased to 44 , so that in the legislature the Whigs now had 44 members in the House and 9 in the Senate, a total of 53 and the Democrats had 56 members in the House and 24 in the Senate, a total of 80 . There were 133 votes on joint balílot and it, therefore, required 67 votes to elect a Senator. The Democrats had a clear majority of 13, but no one knew how many of the Democratic members were Anti-Bent on. The maps and statistics inserted show that the Whigs made considerable inroads upon the Democratic strongholds, especially in the contest for members of the legislature. They even secured two of the three representatives from Howard County, the home of the Central Clique, and it may have been that Jackson's opposition to Benton on the Texas question was what saved him. The Missouri Register claimed an Anti-Benton majority of four votes.(3) The Reporter claimed Benton was

(1) Statesman, Nov. $29, \overline{1} 1844$.

(2) Statesman, Sept. 8, 1848. Official returns for all except three counties. These were border counties and Democratic.

(3) Missouri Register, Aug. 27, 1844. 


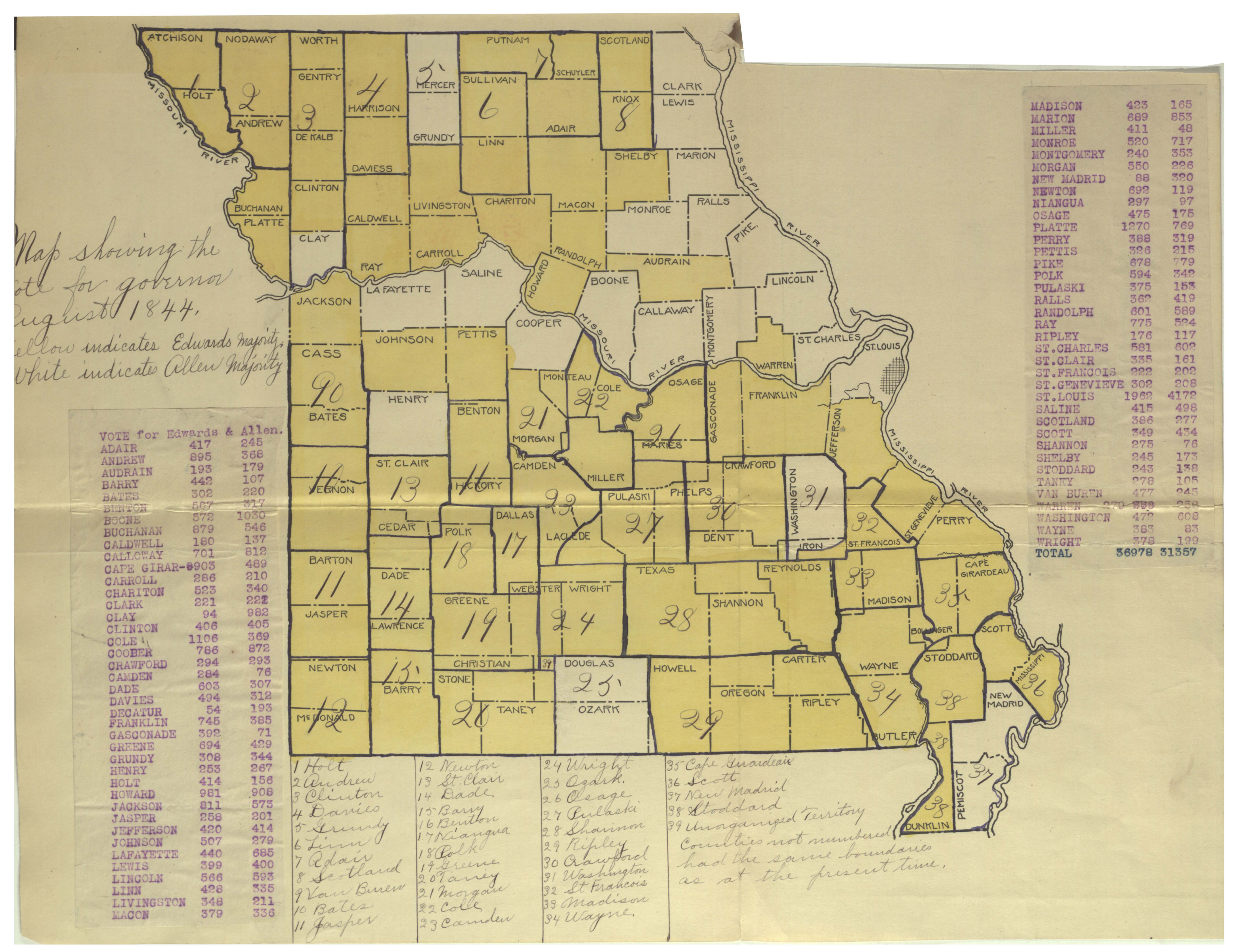



beaten by eight votes.(I) On the other hand, the Inquirer claimed Benton's election by from 16 to 20 votes.(2) Thus the August election did not deternine the contest.

The Anti-Benton Demoorats redoubled their efforts after the election. Every issue of their press was full of attacks upon Bentcn. With the state campaign over the editorials turned more on national issues. All kinds of efforts were made to cast reflections upon Benton and bring him into dis repute. The charge that Benton was really against the national ticket was renewed. The Reporter quoted Benton as replying to a compromise proposition that was made to him at the national Democratic convention at Baltimore, to the effect that Mr, Van Buren withdraw, by saying, "I will see the Democratic Party sink fifty fathoms deep in the middle of hell fire before I will give way one inch with Mr. Van Buren. If we cannot obtain victory with Mr. Van Buren we do not want victory and will not have it."(3) The editor comments, "This is 'union, concession, harmony, everything for the cause nothing for men' with a vengeance."

The Anti-Benton press claimed that Benton in his Texas speeches was continually giving the Whigs material to use effectively against the Democrats. To prove their point they sald that the Whigs had circulated 15000 copies of (1) Missouri Reporter, quoted in the statesman of Sept.6'44. (2) Inquirer, Aug. 16, 1844 .

(3) Reporter, quoted in the Register of August 27, 1844. 

Col. Benton's speech on Texas in Maine as campaign literature.(I) He was assailed for not living in the state. "Missouri", it was said, "had long been a kind of political principality for him, while his residerce has been in Virginia and Kentucky".

The violence of the contest was shown by personal attacks made on Benton. His vote was challenged in St. Louis by a Whig who asserted that Benton did not live in the state, and he was compelled to swear that St. Louis was his residence(3) Col. Bent on had been a director in the old Territorial Bank of Missouri, which had failed in 1819. Some one got a juagment against the Bank and failed of course to get the money - then had Benton arrested for debt. He was compelled to plead privilege from arrest as a member of Congress. (4) This was done in 1843 and repeated in September 1844. The Missouri Register without any explanation of the nature of the debt said, "Col Benton arrived in St Louis the first of the week and the sheriff served a writ for debt on him the next day after he arrived. Is it not strange that that Col. Benton should be thus used? Certainly it is no credit to him, much less to the state of Missouri after it has fattened him for a quarter of

a century". (5)

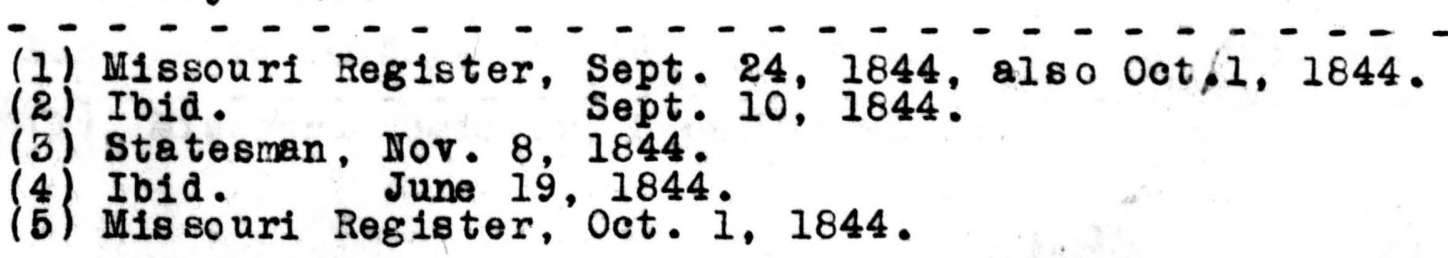



While Benton was never directly accused of accepting mone $\mathrm{y}$,insinuations were cast upon his honesty in carefully worded language. The following is an example, "Wherever he goes, whatever he does, he shows but one characteristic - that of a blustering, insolent, unscrupulous demagogue, . . Many people have wondered why Benton has pursued a course so suicidal to his political reputation. - . . Benedict Arnold, smarting under the reproofs of General Washingt on, and in need of money, bargained for the sale of West Point. Bent on writhes under the repeated reproofs of Democracy and is poor. It has been charged in the National Intelligencer, and as yet not denied, that it is the recipient of Mexican gold in return for its opposition to Texas. Mexico, France, and Englend are opposed to the annexation of Texas and they have the money and to spare."(I) such was the character of the attacks made on Benton between August first, the date of the election of the legislature, and its assembling in the latter part of November.

According to letters of correspondents of the Inquirer atiempts were made to organize the Whig and a part of the Democrat ic members against Benton. Petitions were circulated in some of the counties where it was thought that Democratic members of the legislature might be influenced

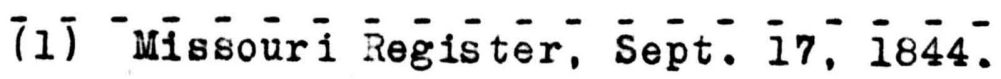



against Benton. These petitions were addressed to the legislator and asked him to vote for some good Democrat instead of Benton. One correspondent said that what the Softs could not effect by open warfare, he feared some more insidious, was endeavoring to effect by strategm, which was only softism in a new form. The former was an undisguised attack upon Col. Benton for the avowed object of his political destruction; the latter was slyly and subtly spreading the poison of disaffection. He said that the annexation of Texas was the avowed object of their opposition, but in reality their purpose was the elevation of political intriguers. Another correspondent from Osage County told of the circulation of a paper for signatures, to instruct the representative to vote for any other good Democrat in preference to Col. Benton. (2) When the above statements are considered in connection with C.F.Jackson's active opposition to Bent on on the Texas question, and the fact that Osage County was a "Hard" county and had always adhered to the central clique, it would secm that there was not only good ground for questioning Jackson's loyaliy to Benton, but also strong reasons for condemning his motives for and methods of opposition, if the inference that he was the political intriguer in whose behalf the papers of instruction were being circulated was true.

(I) Jefférson Inquirer, Sépt. $\overline{26}, \overline{1844}$.

(2) Ibid. 

The Texas question was still the most important issue as it had been before the Augast election. A good many Texas metings were he ld and resolutions were adopted favoring annexation. In Benton's speech on Texas he had always declared himself in favor of annexation at the earliest practicable moment. Texas meetings where Bent on's friends prevailed adopted resolutions using the expression "earliest practicable moment", while those meetings where Benton's friends were in a miniority used the word "immediate" in their resolutions. C.F.Jacks on adảressed a Texas meeting in Randolph County (one of the extreme"Hard" counties that had always lined up with the Central Cliquel, which declared for the "immediate" annexation of Texas, and also organized a league (patterned after the organization of a political party) for the purpose of pushing immediate annexation without the consent of Mexico.(1)

A great Democratic rally was held at Hannibal in October. Benton was there and spoke upon the annexation of Texas. He emphasized the necessity of acquiring Texas, but also emphasized the desirability of keeping the peace and building up our commerce with Mexico. He said, "However, there might arise circumstances in which it would be necessary to annex Texas without Mexico's consent. For example if Great Britain, or any other foreign pover should interfere it would become the duty of the United States to act at once without regard to Mexico". He said that his bill provided for such cases. Later in the day his speech was answered by C.F. Jackson who advccated (1) Jefferson Inquirer, Sept. 26, 1844. 

immediate annexati on without the consent of Mexicd! The Grand River Chronicle quoted from Bent on's speech and commented, "This is coniliatory, more so than we expected, and we do not despair of seeing Benton and Atchison going hand and hand for the attainment of this great American measure on terms alike satisfactory to their constituency and the nation at large."(2) Benton in his Hannibal speech referred to his position as a supposed candidate for the United States Senate. He had spoken of it once before and had said that having been in the senate for twenty-five years he did not ask a fifth election, that he was passive and neutral in the question, and left the decision to his political friends, the Hards/3He now repeated what he had said at Boonville and said further that it now became him to be more explicit, and to say that he should withdraw his name from the canvass if he found any dissention or division among his friends. He would not be the cause or subject of any dissention among them. No such dissention could take place without injury to the party, - without impairing its harnony and unity, - without, perhaps, leading to incurable division; and this was a consequence he was irrevocably determined should never take place on his account. He repeated he would take care to have his name wi tharawn, if there was any division among his friends, the Hards, to whose decision, in all other respects, he committed his fate. (4)

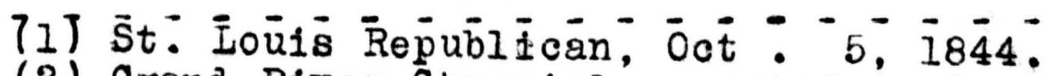

(2) Grand River Chronicle, quoted in Inquirer of Nov.14, 1844. (3) Bent on's Boonvilie speech, Published in Inquirer, $7 / 25 / 44$. (4) Benton's Speech at Hannibal Oct. I, Inquirer, Oct. 17, '44. 

The senatorial contest was hanging in the balance. No one knew what the result would be. The date for the asserabling of the legislature was the third Monday in November. On November 5th, the Missouri Register said, "We trust the two Houses united will relieve our magnificent state of Benton usurpation. We hope they will let him live at home and relieve their constituents from the necessity of sending abroad for a man to represent them in the Senate of the United States. The Democracy of Missouri have done with him. He has impuned our cause more at the present election than any ten Whig leaders have done. Let Bent on be elected to the United States Senate once more and Missouri will be a Whig state in 1848. On the other hand the Inguirer of November 14, said, "At the approaching session it is believed opponents of Col. Benton will let nothing go amiss which would have a tendency to cause, or secure his defeat. What the result will be, and how far they will prove successful, a few days will determine. They are active and diligent, and their plans should be well guarded against".

From the above quotations from two of the lesding papers of the state, one Anti-Benton and the other Benton, it is clear that neither side was very confident of success. Both were on the alert and ready to take advantage of the slightest opportunity to accomplish the defeat or election of Benton; but neither of the above quotations sounds like the language of a man who was really confident that his party would be successful. 

As the date of the meeting of the legislature drew near the political tension became more intense. There were reports that Jackson would become a candidate against Benton for the Senatorship.(I) The poliifians gathered early, not only the members of the legislature but it appears that the Benton men had as many of their influential people come to Jefferson City as posible on one pretext of another and then work for Bent on on the side. The correspondent of the Republican said that there were nearly one hundred men there seeking to be selected as messenger to Washington, D.C. to carry the official electoral vote, all of them active Bentonians(2) There were ma conferences and much caucusing and at this kind of work the Benton men proved themselves superior to their opponents. What was accomplished by them is best told in the words of the correspondent of the St. Louls Republican. Writing before the meeting of the legislature he said, "Jackson is to be elected speaker. In this there is a double operation. In the first place, the election of Mr. Jackson to the office of Speaker will buy him off from contending against Col. Benton for the Senatorship, - a fear which has been pretty widely entertained, and in the next place, it once more manifests the influence of the Colonel's favorite measures in the House. (3)

St. Louis Republican, Noveraber 21, 1844. Ibid. Ibid. Novernber 22, 1844. November 21, 1844 . 

The chief clerkship is to be given to Mr. Huston as a reward for the part he played in support of the Colonel's currency measures.(1) Later he said,"The caucus held this morning was not harmonious but the offices of speaker, chief clerk, etc. were settled. All applicants were required to give a pledge to support Col. Benton, - Jackson whose reported split with Benton on the Texas question has been so rife goes the whole figure."(I)

The legis lature met on November 18th. Jackson was elected Speaker and Huston Assistant clerk. Thus the Hards controlled the organization. After the organization was effected a caucus was held in the Senate chamber. According to the correspondent of the Republican, "The object was to whip the few softs into the traces, and to obtain their pledge to support Col. Benton. The meeting was by no means harmonious and two or three withdrew refusing to pledge them selves. The caucus determined to bring on the election at an early day this week. If they can succeed, the election will probably take place Wednesday or Thursday. The opponents of Col. Benton will attempt to procrastinate, and if they succeed the Colonel's election may be regarded as doubtful.(2)

On the afternoon of the 19th Senator Fort submitted a joint resolution "to go into the election of Senator of the United States to supply the vacancy occasioned by the (1) St. Lou is Republican, Nov, 2L, 1844.

(2) Ibid. 

death of Senator Iinn, and also the election of a Senator to supply the place of Hon. Thos. H. Benton, whose term of service expires on the 4th day of Mareh, 1845, on tomorrow at two O'clock P.M." Mr. Ellis, Democrat from the Eighth Senatorial district located in the Northwest, moved to lay on the table, which motion was lost, ayes 14 , nays 19. As there were 24 Democrats and only 9 Whigs in the Senate, five Democrats have voted for the Ellis motion to table the resolution. Ellis then submitted as a substitute for Fort's resolution, a resolution favoring the immediate annexation of Texas. The President decided the substitute was out or order. Ellis then moved to amend Fort's resolution by striking out all that portion after the word "also." The effect of the amendment would have been to elect Atchison at the foint meeting and postpone the election of Benton. The amendment was lost, ayes 14 , nays 19 . The resolution was then passed, ayes 20, nays 13. (1)

(I) Senate Journal, pp. 42, 43 . The Democratic Senators voting to delay the choice of a Senator for the long term were: Anderson from St..Louis; Boggs from the 14th district composed of Jackson, Bates and Van Buren; Detchemendy from the 25th, composed of Lincoln, Montgomery and Adair; and Ellis from the $8 \mathrm{th}$ composed of Clinton, Carroll, Caldwell and Daries counties. Detchemendy voted for the resolution thus changing the line up 20 to 13 instead of 19 to 14 as it had been on the other votes. 

When the resolution came up in the House, Hough, a Democrat from Scott County, in Southeast Missouri, introduced a series of resolutions, the purport of which was to approve the course of Atchison and to condemn that of Benton upon the Texas question. This was an effort to delay the action of the House upon the Senate resolution until after the time named for the joint meeting, but the speaker decided that as they were concurrent they should lay on the table one day before being considered. Mr. McHenry of Bates County, offered the following resolution: "That the Senate be informed that the House will be ready this day at two o'clock P.M. to proceed to the election of two Senators to the Congress of the United States for the State of M1ssour1"11) Mr. Davis, a Whig from Howard County, objected to the consideration of the resolution as being out of order. The speaker decided the consideration of the resolution to be in order, whereupon, Davis appealed from the decision of the Speaker to the House and demanded the ayes and nays. The Speaker was sustained by a vote of 78 to 16 . Mr. Perryman, Whig from Washington County, then moved to adjourn, but the motion was lost by a vote of 60 to 37 . Mr. Hough, then moved to postpone the consideration of Mr. MoHenry's resolution, until to-morrow at two o'clock P.M. but his motion was voted down 55 to 41 and McHenry's resolution was adopted by the same vote. There were 44 Whig mem- 

bers in the House. It w1ll be noted that in no instance during the fight to delay the election of Benton did the Whigs cast their full vote against the Benton men.

When the two Houses met in joint session Atchison was nominated for the short term by Mr.Fort, leader of the Benton men in the Senate, and received 101 votes. (I) Twenty-one of those voting for Atchison were Whigs. There were 133 members and, therefore, 67 votes were required to elect. Only scattering votes were cast against Atchison and he received 34 votes more than were necessary. For the long term Mr. Monroe, Senator from the 20th district, composed of Morgan, Miller, Camden, and Pulaski counties, nominated Col. Benton; and Senator Anderson, Soft Democrat from St. Louis, nominated Thos. B. English, a Soft from Cape Girardeau County. Polk, Senator from the 26th district composed of Shannon, Ripley, Madison, and Wayne counties, desired to know upon what authorlty Anderson nominated English. Anderson said that he had assurances from English's friends that if $\theta$ lected he would serve. Snyder, Senator from Cape Girardeau County, said that he had authocity from English to say that he did not desire his name to be placed in opposition to Col. Benton. (2) Soon after the election English wrote a letter to snyder and thanked him for what he had said con(I) House Journal, $\bar{P} 3 \overline{9}$.

(2) St. Louis Republican, Nov. 25, 1844. 

cerning his position toward Col. Benton and declared that he had never given his consent for his name to be used, and that he would under no circumstances have allowed it to be used in the contest against Col. Benton if he had been consulted. Benton received 74 votes, Engl ish 32 and the other votes were scattered.(1) Benton had a margin of only 8 votes which in itself is significant when it is remembered that the Democrats had 80 members in the legislature, and that Atchison's margin was 34. An analysis of the vote shows that two Whigs voted for Benton and 8 Democrats failed to vote for him, that most of the Anti-Benton Democratic vote was in the Senate and came from the hold-over Senators, and further that it came from the Northwest and the Southeast as is shown by the color maps.

The Anti-Bent on forces, clearly, had failed to perfect any coalition whereby they could cast their entire vote for one man, and their tactics were to secure time for organization. On the other hand, the Democratic organization had succeoded in controlling all the newly elected members except three.

The correspondent of the Republican in commenting upon Benton's election said, "Bent on recelved eight more votes than necessary to elect. If five of those who voted for him had voted against him he would have been defeated; for it is (1) Housé Journai, P $4 \overline{0}$. 

very certain that all of the scattering votes would have been given to English if it had not been known that the party had a rranged the matter. There were more than five who, it is fair to infer, did not represent the will of their constituents." He then enumerated a number who cast the ir votes for Benton, but who, he said, should have voted against him: Welbourn, of Pike County, was a hold-over senator but the county had been carried by the Whigs at both the August and the November elections; Richmond of Marion County had been elected with the understanding that he would represent the wishes of his constituents and his country had gone for Clay by several hundred; Boas of St. Genevieve had instruetions from his constituents to vote against Benton in his pocket when he voted for him: Buford of Madison, French of Dade, McClure of Warren, MoHenry of Bates, Salmon of Davis, Smith of Clinton, Warren of Camden, and Wilson of VanBuren were either elected on pledges to vote against Benton or as Anti-Benton men. Some of them, it was alleged, pledged themselves repeatedly on the stump to oppose Benton's reelection.(I) Here are eleven men, most of whom, at least, had been brought to the support of Col. Benton through the pressure of the organization. Indeed the power of the party organization was so great that it not only whipped the soft members of the legislature into line, but it prevented any Soft leader of prominence from becoming an active candidate 

against Bent on or even openly allowing the use of his name for such a purpose. Thus it appears that the party organization saved Benton in 1844 .

The Hard press was jubilant. The papers praised Benton very highly. All open opposition seemed to melt away and while Benton's victory was by a very narrow margin it appearldto be complete. The Inquirer editorially expressed the feeling of Benton's friends thus: "Col. Benton may have differed with some of his friends upon the Texas treaty, but that difference did not even amount to a good hobby for his enemies to secure his defeat. His election is now over. He still has the confidence of his party and in no better way could they show it than they have. His services are well appreciated by the Democracy of Missouri. Glorious 0ld Tom Benton is triumphantly reelected to the Senate of the United States for six years from the fourth of March next. Proclaim this throughout the Union and the response of the Democracy will be, "All's well".(I)

(I) Jefferson Inquirer, Nov. 21, 1844 . 


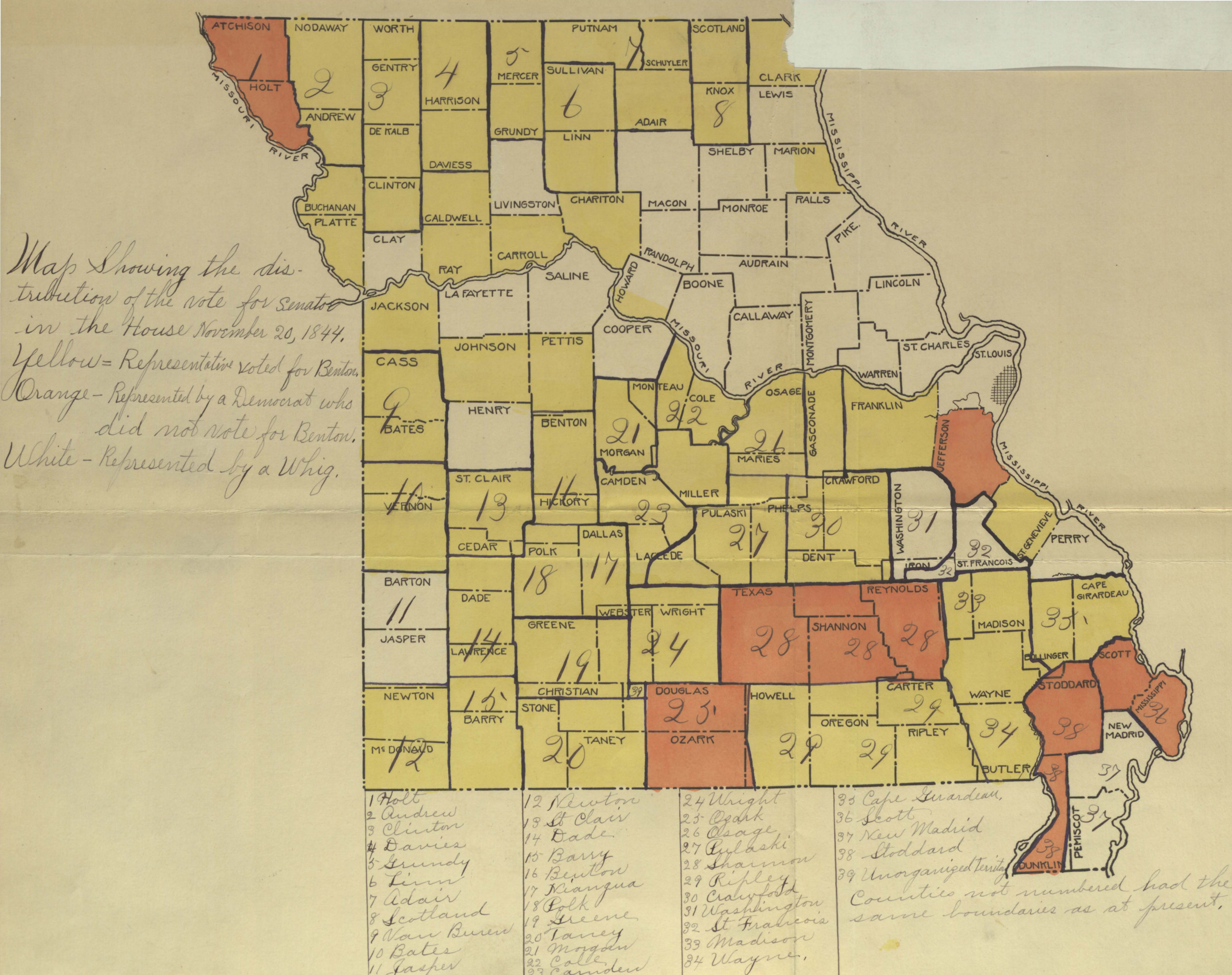




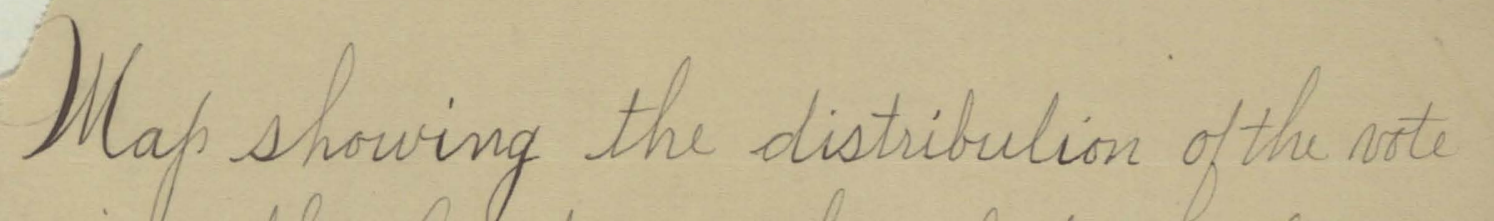
in the senate on the election of Senator November, 20 1844. SHATT CLINTON: CHARITON MACON SHELBY  JACKSON 30

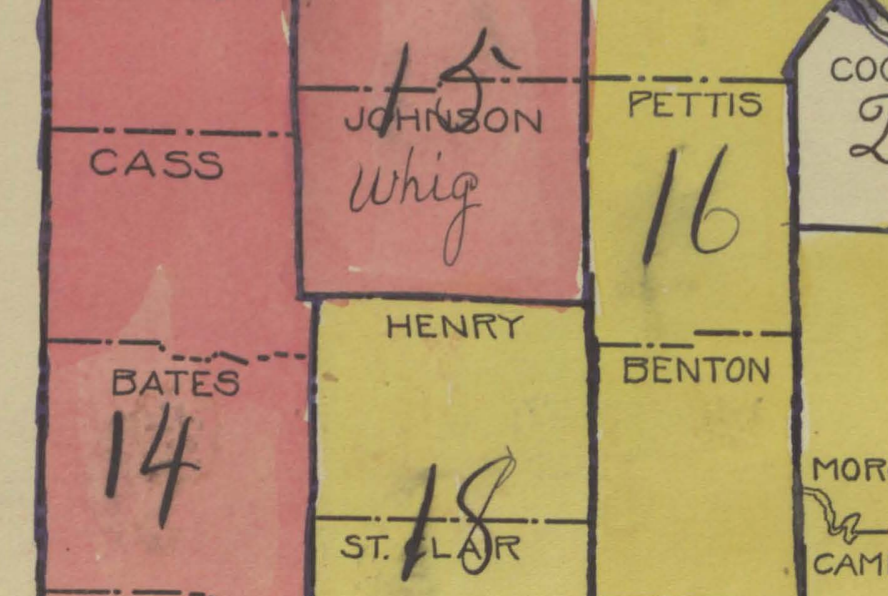
VERTNON Hellow indicates vote for both Atchison and Bentor, Red indicates vote for Athison but not for Bentor Whiti indicates that the serratois wote was nis cast for either Atchiom or Pentor. 3 . fellow - voted for both Benton and Atchion. Red-voted for Atchism but not for Benton.

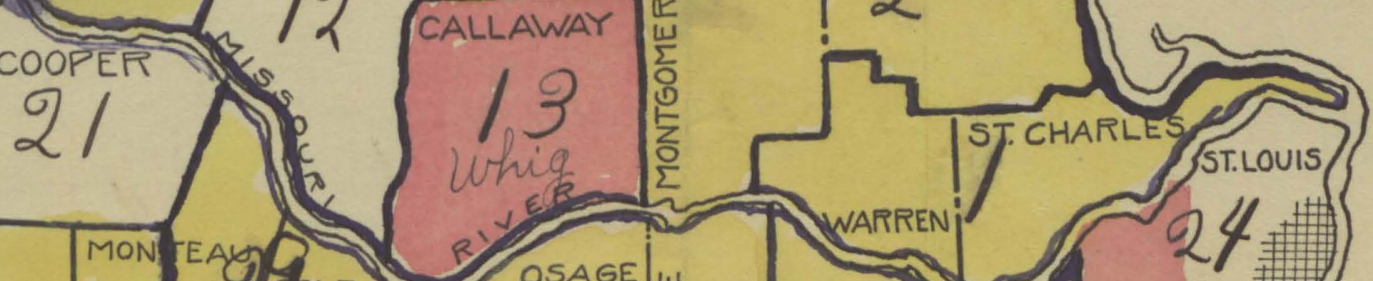

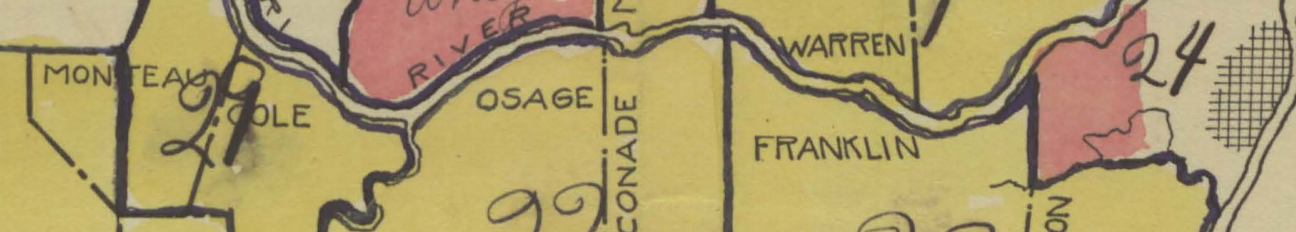
23 危

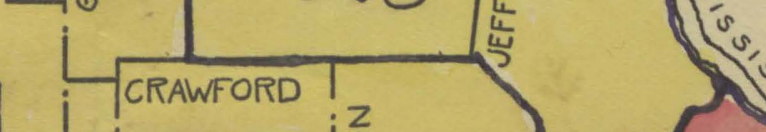





\section{BIBIIOGRAPHY.}

I Source Material.

1. Laws and official journals. Congressional Globe

Vol. 10, 1841-42.

Vol. $13,1843-44$.

Missouri

Constitution of 1820 .

House Journals; 1840-41, 1842-43, 1844-45.

Laws of, 1836-37, 1840-41.

Revised Statutes of, 1845 .

Senate Journals; $1840-41,1844-45$.

United States Census Report of 1850, table XXXIV.

2. Newspapers.

Jefferson Inquirer ("Hard" Democratic.) Jefferson City, Jeffersonian Republican. ("Hard" Dem.) Jefferson City, Mo. Files 1841 to 1844 .

Miss ouri Intelligencer. (Whig) Fayette, Mo.

Files Apr.23, 1819 to Dec.5,1835.

Miss ouri Register ("Soft" Dem.) Boonville,Mo.

Files from May, 1840 to June, 1841 also from August, 1843 to 1845.

Missouri Statesman. (Whig) Columbia,Mo. Complete files from 1843 on. St. Louis Republican. (Whig) St. Louis, Ma. Complete daily files for entire period.

II Secondary material.

Benton, Thos. H. Thirty Years' View. New York, 1897.

Conant, Charles A. A History of Modern Banks of Issue. New York, 1902 .

Darby, John F. Personal Recollections. St. Iouis,1850.

Edwards \& Hopewell. The Great West. St. Iouis, 1860.

Knox, John Jay, History of Banking in the United States. New York, 1903.

Mcllaster, John Bach, A History of the People of the United States, Vo1. VII, New York, 1910.

Ray, P. Orman, The Repeal of the Missouri Compromise. Cleveland Ohio, 1909.

Scharf, J. Thomas. History of St.Louis City and County. 2 Vol. Philadelphia,1883. 



\title{
APPEIDIX.
}

Newspapers of the Period. (I)

\begin{abstract}
Argus.
The ancestor of the Globe Demoorat was originally the Workingman's Advocate, a paper established in St. Iouis in 1831. The Adrocate was sold to Bowling and Mayfield who changed its name to the Argus and made it Democratic. In 1838 it was purchased by Mayfield, Iawhead and Corbin and became a daily. In 1839 it became the property of Andrew J. Davis who made William Gilpin editor. In June 1840 Davis was killed by William Darnes in a quarrel over politics and Corbin became proprietor. In 1841 the Argus failed and Shadrick Penn bought the plant and started the Mis souri Reporter.
\end{abstract}

\section{Boonslick Democrat.}

Was founded in 1834 by W. B. Napton, later attorney-general and for twenty four years supreme judge of Missouri. The Boonslick Democrat was a radical Hard paper and the chief organ of that part of the Central Clique known as the Fayette Clique. It was published at Fayette and failed in the summer of $18: 3$. William A. Hall, afterwards circuit judge, purchased the plant and started the Missouri Democrat.

\section{Boonville Argus.}

The Boonville Argus was established in Boonville in August, 1843, (1) The following material was found in the newspapers of the period (chiefly the Statesman and the Inquirer) and in the (PHistory of the Country Press" by Miss Minnie Organ, Columbia, lio. 1910. Unless otherwise stated the papers are known only through other newspaper reference. 

about the time of Benton's visit to Boonville. It was started by the Hards for the purpose of upholding the "pure" Democracy and fighting the Missouri Register. There is very little reference to it.

Grand River Chronicle.

The Grand River Chronicle was published in Chillicothe,Missouri, It was established in 1843, edited by James H. Darlington, and was an Anti-Benton Democratic paper; but lined up for the organization ticket after the state convention of 1844 .

\section{Glasgow Pilot.}

The pilot was started in 1843 at Glasgow by J.T.Quesenberry, and in 1844 was bought by James A. DeCourcy. It was Liberal Democratic in politics.

\section{Jefferson Inquirer.}

The Inquirer was established at Jefferson City in 1838, by E.I.Edwards and John McCollough. McCullough died in 1839 and in 1840 Edwards sold out to William Iusk who was editor until his death in 1844. His son James lusk then became editor and continued the publication of the Inquirer until his death in 1858. The Inquirer was a Hard Democratic paper, always a strong champion of Thomas H. Benton and later a strong Union paper. Files from 1840 to 1849 are accessible in the state Historical Society Iibrary at Columbia,Missouri. These files 

form a very important source for the period. Jeffersonian Republican. The Jeffersonian Republican succeeded the Jeffersonian in 1827. It was published at Jefferson City by Calvin Gunn and Franklin Dunnicia until 1831, after that year by Dunn alone until his death in 1844 when its publication ceased. It was a strong supporter of Andrew Jacks on a bitter enemy of the Whigs and a Hard. The paper declined during its last years and is not a very valuable source for the period preceeding the campaign of 1844. The State Historical Society at Columbia,Missouri has the files from 1841 to 1844 .

\section{Iiberty Banner.}

The Tiberty Banner was established in 1843, at Iiberty in Clay County. It was edited by DeCourcy and Routt, and was a radical Iiberal Democratic paper.

\section{Miss ourian.}

There were several papers called Missourian. One was published in St.Charles from 1820 to 1826, another at Fayette from 1837 to 1840, and still another at Warsaw in 1841. But the Missourian referred to was established in st.Iouis in the summer of 1843 for the special purpose of sustaining the cause of "pure" Democracy in that City. It was edited by Van Antwerp a Democrat from Iowa. It fought the Reporter with special ardor during the campaign of 1844. In 1846 it was united with the Reporter and became the Union. 



\section{Missouri Courier.}

The Courier was established at Palmyra in 1832, edited by Jonathan Angevine until 1837 when James I. Minor, later secretary of state, became editor. In 1841 Joseph B.Ament secured the Courier, and it became "Soft" during the campaign of 1844 . Later it was moved to Hannibal and became the Hannibal-CourierPost.

\section{Hissouri Reporter.}

The Reporter was established in St. Louis by Shadrick Penn, an old and experienced Democratic editor from Louisville,Kentucky, in December 1841, on the muins of the Argus. It soon became a Iiberal Democratic paper and the strongest Anti-Benton paper in the state. It was a daily and was published until Penn's death in 1846 when it was united with the Missourian fo form the "Union." Iater the Union was merged with the "Signal" to form the Missouri Democrat, one of the progenitors of the Globe Democrat. The Reporter (except a tew copies of the year 1846 in possession of the Mechantile Library, St. Louis) is known only through quotations and newspaper references.

\section{Miss ouri standard.}

The Standard was a Hard Democratic paper started in St.Iouis in the spring of 1843 for the purpose of opposing the Reporter. It never succeded well and after three months was succeeded by the Missourian. 



\section{Missouri Intelligencer.}

The Missouri Intelligencer was established at Franklin in what is now Howard County, as the Missouri Intelifgencer and Boonslick Advertiser by two Virginians, Patten and Holliday, April 23, 1819. In 1826 the paper was moved to Fayette and in 1830 to Columbia, and in 1835 was bought by James S. Rollins and others and became the Patriot. The Intelligencer was a strong Whig paper. The State Historical Society has files from 1819 to 1835 .

\section{Wissouri Democrat.}

Several Missouri Democrats" have existed in the Newspaper world, but the one referred to was esteblished by William A. Hall on the ruins of the Boonslick Democrat in December,1843. It was Hard Democratic, beceme the mouth piece of the Fayette Clique, and was a strong Benton paper. Its publication was discontinued in December, 1844 .

\section{Miss ouri Statesman.}

The Statesman was a Whig paper established in Columbia, lisisouri, in 1843 by William F. Switzler. It was owned and edited by Switzler for forty two years and is still one of the leading papers of Columbia. Complete files from 1843 on are in the State Historical Library at Columbia,Missouri. It is very valuable for official reports, comments upon the press of Missouri and political criticism. 



\section{Missouri Register.}

The Register was established at Boonville,Missouri, in 1839. In 1843 Captain Ira Van Nortwick became owner and publisher and made the paper "Soft." Van Nortwick attacked Benton with such vigor that the Register came to be recognized as the leaaing Iiberal Democratic paper of the state outside of St.Louis. After 1845 the Register passed through a number of hands and finally ceased to exist in 1853. The State Historical Society at Columbia,Missouri, has files from May,1840, to June 9, and from August 9,1843 , to July 9,1845 .

\section{New Era.}

The New Era was a Whig paper established in St. Iouis in 1840 by Nathaniel Paschall. Paschall had been one of the owners of the St.Louis Republican until 1837 when he sold out. In 1844, after having edited the New Era for four years, he again became associate editor of the Republican and no more is found concerning the New Era.

\section{Osage Yeoman}

The Osage Yeoman was a Iiberal Democratic paper started at Warsaw by W.T.Yeomansin 1843. It was radically Anti-Benton. Yeoman sold out in 1845 to $\mathbf{F . W}$. Cameron who changed the name to Saturday svening Visitor, and made it neutrel in politics. Ozark Eagle.

The Ozark Eagle, first called the Ozark Standard, was established at Springfield,Missouri, in 1838 by Cyrus W.Stark. It was the first paper in the ozark region. Stark sold to Mitchel and McKinney who changed the name to the Ozark Eagle and published 

it until 1842 when it was suspended. In the summer of 1843 the Springfield Advertiser was started from the Eagle plant. The Eagle was a rabid Anti-Benton, Anti-Central Clique paper. Paris Sentinel.

The Paris Sentinel was published at Paris,Missouri from 1837 to 1843, when it became the Paris Mercury and its politics were changed from Democratic to Whig. The Sentinel was a Hard Democratic paper edited by General Easton.

\section{Platte Fagle.}

The Eagle was established at Platte City in 1842 by E.Sangston Wilkerson, edited by Allen McIean. It was moved to Weston in December, 1842. MoIean bought it and moved it back to Platte City in 1844 and changed the name to Platte Argus. It was a Hard Democratic paper and a strong supporter of Benton in the campaign of 1844 .

Patriot.

The Patriot was a whig paper published by a company headed by James S. Rollins, who bought the Missouri Intelligencer in 1835. After one or two changes in ownership the Patriot was purchased by Wm. F. Switzler and became the Missouri Statesman. The files from March 1841 until it was changed to the statesman January 1, 1843 are in the State Historical Society Iibrary at Columbia, Miss ouri.

\section{St, Iouis Republican.}

The Republican was a daily whig paper during the period 1839 to 1845. The Republic of St.Iouis has the complete files. They are very valuable for St. Louis conditions and the account 

of Benton's election in 1844.

\section{St. Iouis Inquirer.}

The St. Iouis Inquirer was established in 1818 by Isaac I. Henry, Evarist Maury, and Col. Benton. Benton was the chief editor until he became senator in 1820. Henry died and laury withdrew, and Patrick H. Ford took possession of the office for Benton in 1820. Ford retired in 1824 and was succeeded by Duff Green, afterwards editor of the United States Telegraph, who purchased the In uirer in 1826. It was sold to I.E. Iawless and became the St. Iouis Beacon in 1828. The Inquirer is of special interest as the paper in which Benton's early views on the southwestern boundary question and the treaty of 1819 were published.

\section{St. Iouis Beacon.}

The Beacon was established in 1828, by I. E. Iawless who had bought the St. Louis Inquirer. The Beacon was published until 1832, and is of special interest as the paper in which Benton's letters, signed IaSalle, and advocating the annexation of Texas, was published.

\section{Western Miss ourian.}

The Restern Missourian, was established under the name of Chronicle, at Independence in 1840 by Joseph Iancaster. In $1841 \mathrm{R}$. Vinton Kennedy bought a part interest in it and the name was changed to the Western Missourian. It failed in July 1843. It was a Hard Democratic paper. 






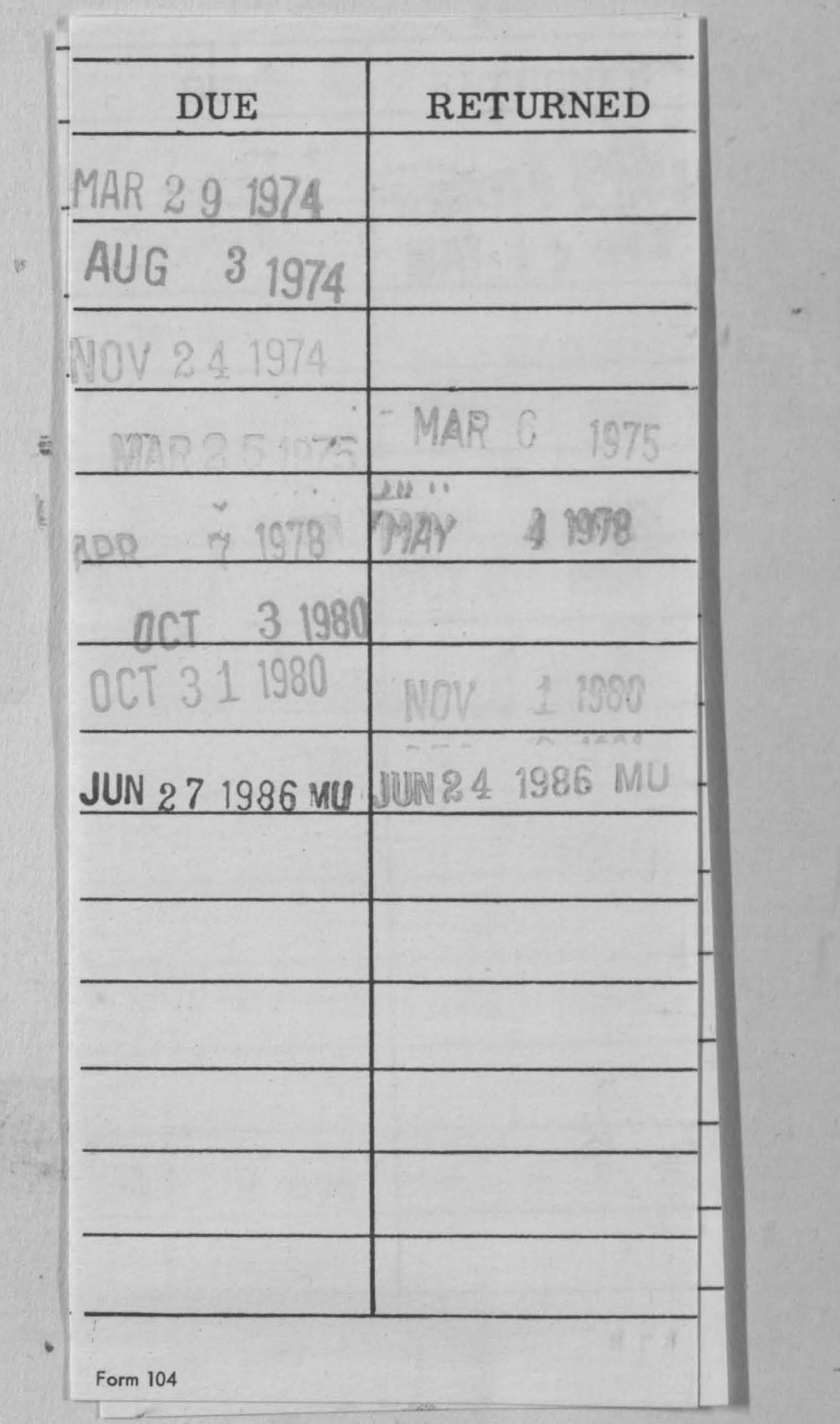


$\therefore+2$

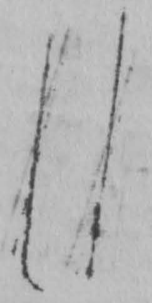


